\title{
Taxonomic review of the Dichotomius (Luederwaldtinia) agenor species group (Coleoptera: Scarabaeidae: Scarabaeinae)
}

\author{
Santiago MONTOYA-MOLINA ${ }^{1, *} \&$ Fernando Z. VAZ-DE-MELLO ${ }^{2}$ \\ ${ }^{1}$ Federal University of Mato Grosso, Institute of Biosciences, Programa de Pós Graduação em \\ Ecología e Conservação da Biodiversidade, Av. Fernando Correa da Costa, 2367, Boa Esperança, \\ Cuiabá, MT, Brazil. \\ ${ }^{1}$ Faculty of Environmental Sciences, Czech University of Life Sciences Prague, Kamýcká 129, \\ Praha-Suchdol, 16500, Czech Republic. \\ ${ }^{2}$ Federal University of Mato Grosso, Institute of Biosciences, Department of Biology and Zoology, \\ Av. Fernando Correa da Costa, 2367, Boa Esperança, Cuiabá, MT, Brazil. \\ *Corresponding author: horomo@gmail.com \\ ${ }^{2}$ Email: vazdemello@gmail.com \\ ${ }^{1}$ urn:1sid:zoobank.org:author:BC00697E-4F30-497A-A9C3-0C8E7B11B625 \\ ${ }^{2}$ urn:lsid:zoobank.org:author:2FF2B7D6-1A6B-43C1-9966-A1A949FB2B05
}

\begin{abstract}
The Neotropical D. agenor species group of the subgenus Luederwaldtinia Martínez, 1951 is taxonomically reviewed. After examination of specimens in collections, the $D$. agenor species group will consist of seventeen species, a leap from the former nine species: D. agenor (Harold, 1869), D. amplicollis (Harold, 1869), D. belus (Harold, 1880), D. centralis (Harold, 1869), D. deyrollei (Harold, 1869), D. sagittarius (Harold, 1869) stat. rev., D. tristis (Luederwaldt, 1923), D. triquetrus (Luederwaldt, 1923), D. validipilosus (Luederwaldt, 1931), D. fornicatus (Luederwaldt, 1931) [transferred to D. lucasi species group and to which D. bosqi (Pereira, 1941) is considered to be a new synonym], D. inachoides (Felsche, 1901) [transferred from the group fisus (Selenocopris)], D. simplicicornis (Luederwaldt, 1935) [transferred from the group fisus (Selenocopris)], D. subaeneus (Castelnau, 1840) [transferred from the D. carbonarius species group], D. rafanunezi sp. nov. from Mato Grosso, D. henripittieri sp. nov. from Venezuela and D. enioi sp. nov. from Guatemala and Costa Rica. This review was based on external morphology and characters of the male genitalia (aedeagus and internal sac). Descriptions of new species and redescriptions were made after examining the typespecimens of the already described species. Lectotype designations, species revalidations, redescriptions and new species descriptions are provided.
\end{abstract}

Keywords. Dichotomiini, dung beetles, Neotropics, new species, taxonomy.

Montoya-Molina S. \& Vaz-De-Mello F.Z. 2021. Taxonomic review of the Dichotomius (Luederwaldtinia) agenor species group (Coleoptera: Scarabaeidae: Scarabaeinae). European Journal of Taxonomy 734: 1-64. https://doi.org/10.5852/ejt.2021.734.1233

\section{Introduction}

Dichotomius Hope, 1838 is one of the most diverse and abundant dung beetle genera in Neotropical ecosystems. It currently includes around 170 valid species (Nunes \& Vaz-de-Mello 2013; Arias- 
Buriticá \& Vaz-de-Mello 2012; Nunes et al. 2016) and is divided into four subgenera as supported by Martínez (1951): Dichotomius s. str. approx. 70 species; Luederwaldtinia Martínez, 1951, 67 species; Homocanthonides Luederwaldt, 1929, monotypic and Selenocopris Burmeister, 1846 with 25 species (Martínez 1951; Vaz-de-Mello et al. 2011; Nunes \& Vaz-de-Mello 2013).

Luederwaldtinia Martínez is a speciose subgenus that includes 62 species distributed in 13 species groups defined by Nunes \& Vaz-de-Mello, 2013: Dichotomius agenor, D. assifer, D. batesi, D. calcaratus, D. carbonarius, $D$. crinicollis, D. inachus, D. interstitialis, D. micans, D. nisus, $D$. sericeus, $D$ speciosus and $D$. superbus species groups. The $D$. agenor species group is easily distinguished by the presence of: 1) male: head with transverse carina bearing a strong medial tubercle; 2) female: head with transverse bituberculate carina, lacking a medial tubercle; 3) pronotum of male and female simple, at most with a truncate knob on the anterior portion and with fine punctures (Vaz-de-Mello et al. 2011; Nunes \& Vaz-de-Mello 2013). Historically, the D. agenor 'section' included eight species according to Luederwaldt (1929): D. agenor (Harold, 1869), D. amplicollis (Harold, 1869), D. belus (Harold, 1880), D. centralis (Harold, 1869), D. deyrollei (Harold, 1869), D. sagittarius (Harold, 1869) stat. rev., D. tristis (Luederwaldt, 1923) and D. triquetrus (Luederwaldt, 1923).

Species of the subgenus Luederwaldtinia are included in recent regional revisions and catalogue surveys (Kohlmann \& Solís 1997; López-Guerrero 2005; Sarmiento-Garcés \& Amat-García 2014), and in general taxonomic notes and revisions (Maldaner et al. 2015; Nunes \& Vaz-de-Mello 2013; Nunes et al. 2016; Vaz-de-Mello \& Nunes 2016; Valois et al. 2017). Of the twelve species groups listed above, four have so far been taxonomically reviewed: D. assifer (Nunes et al. 2016), D. batesi (partially revised in Vaz-de-Mello \& Nunes 2016), D. speciosus (Maldaner et al. 2015) and recently D. sericeus (Valois et al. 2017).

This work arises from the need of a taxonomic revision of the $D$. agenor species group, the so-called "Pinotus agenor section" (Luederwaldt 1929). The present taxonomic revision includes descriptions of new species, redescriptions of previously known species, illustrated keys for species identification, species diagnoses and a compilation of geographical records of the species assigned to the group.

\section{Material and methods}

Measurements of the length of specimens used in this work were taken from the anterior margin of the clypeus to the pygidial disc in resting position. Widths were taken at the widest point, either of the pronotum or the elytra. The mean of each measurement (length and width) is provided at the beginning of each description. Morphological nomenclature of structures follows that of Vaz-de-Mello et al. (2011) and Nunes \& Vaz-de-Mello (2013). The nomenclature of Medina et al. (2013) of the aedeagus and the internal sac of the aedeagus was used.

\section{Collections studied}

Specimens used in this work are deposited in the following collections, the name of the curator(s) is given in brackets:

BMNH = The Natural History Museum (formerly British Museum, Natural History), London, United Kingdom (Maxwell Barclay)

CEMT = Setor de Entomologia da Coleçao Zoológica da Universidade Federal de Mato Grosso, Departamento de Biologia e Zoologia, Cuiabá, Mato Grosso, Brazil (Fernando Z. Vazde-Mello)

ECC $=$ Colección Escarabajos Coprófagos de Colombia, Bogotá, Colombia (Alejandro Lopera Toro) 

IAvH = Instituto de Investigación de Recursos Biológicos Alexander von Humboldt, Villa de Leyva, Boyacá, Colombia (Claudia Alejandra Medina)
MACN = Museo Argentino de Ciencias Naturales "Bernardino Rivadavia", Buenos Aires, Argentina (Arturo Roig)
MLP = Universidad Nacional de la Plata, La Plata, Argentina (Nora Cabrera)
MNHN = Museum national d'histoire naturelle, Paris, France (Olivier Montreuil and Antoine Mantilleri)
MUSENUV = Museo de Entomología de la Universidad del Valle, Cali, Valle del Cauca, Colombia (Carmen E. Posso)
MZSP $=$ Museu de Zoologia da Universidade de Sao Paulo, Sao Paulo, Brazil (Carlos Campaner and Sonia Casari)
SMTD $=$ Senckenberg Natural History Collections, Museum of Zoology, Dresden, Germany (Olaf Jaeger and Klaus-Dieter Klass)

Dry specimens were hydrated and cleaned by immersing in hot water in an ultrasonic cleaner. Male genitalia were extracted following the widely described method by Zunino (1983), Tarasov \& Solodovnikov (2011), Medina et al. (2013) and Tarasov \& Génier (2015). Using a stereo microscope, entomological forceps and pins, the aedeagus was removed via the pygidium. The internal sac of the aedeagus was extracted using the methodology described by Medina et al. (2013) by gently pulling it through the basal phallobase foramen. The inner sclerites of the internal sac were cleared in $\mathrm{KOH}$, heated in small beakers, for study. The nomenclature of the sclerites of the internal sac also follows Medina et al. (2013).

Type specimen label information was cited verbatim between quotation marks. Labels of the type specimens are separated by a slash "/". Square brackets "[]" were used to describe characteristics of each type label (e.g., [red with black margins], abbreviations used in brief descriptions: [hw] for handwriting; [p] for printed and [phw] for partially handwritten. In the lists of additional or non type material, country names are written in capital letters, the names of the provinces or departments are in bold (e.g.,Valle del Cauca) followed by municipality, geographic coordinates (when available), other complementary information, data and collector.

When necessary, lectotypes were selected and designated from syntypes deposited in the abovementioned collections/museums, to stabilize the nomenclature of the group. Group names used here refer to the oldest available species name in each group (Luederwaldt 1929; Nunes \& Vaz-de-Mello 2013) and do not constitute valid taxonomic entities according to the International Code of Zoological Nomenclature (ICZN 1999).

\section{Illustrations}

All dorsal and ventral photographs were taken using a Canon EOS-T3i camera equipped with a macro lens EF $100 \mathrm{~mm}$ 1:2.8 Macro USM medium telephoto $1.0 \times$ magnification. The camera was controlled by an 'Automated Macro-rail Ford Focus Stacking StackShot' (COGNISYS.INC), which consists of a rail system that electronically controls and coordinates the movement and camera shutter.

For self-stacking of the images, the software Zerene Stacker (ver. 1.04 Build T201602151850) was used, a commercial software that allows the user to simultaneously align and attach images. For photostacking, the PMax method recommended by Brecko et al. (2014) was employed. This method manages large numbers of photographs without affecting the final image.

Photographs of specific characters, male genitalia and measurements were taken using a Leica stereo microscope M205C, with image stacking software (Leica Application Suite (LAS), ver. 4.9.0). Images were edited using Adobe Photoshop CC 2015. Distribution maps were prepared with SimpleMappr (Shorthouse 2010) and are provided in the Appendix. 


\title{
Results
}

\section{The Dichotomius (Luederwaldtinia) agenor species group}

\author{
Class Insecta Linnaeus, 1758 \\ Order Coleoptera Linnaeus, 1758 \\ Suborder Polyphaga Emery, 1886 \\ Superfamily Scarabaeoidea Latreille, 1802 \\ Family Scarabaeidae Latreille, 1802 \\ Subfamily Scarabaeinae, Latreille, 1802 \\ Tribe Dichotomiini Pereira, 1954
}

\section{Diagnosis of the Dichotomius (Luederwaldtinia) agenor species group}

Within the subgenus Luederwaldtinia Martínez, 1951, the Dichotomius agenor species group defined by Nunes \& Vaz-de-Mello (2013) can easily be separated from other species groups by the following morphological characters: head of males bearing a transverse trituberculate carina, medial tubercle higher than lateral ones; in females head carina generally bituberculate or quadrituberculate, except in two species (D. fornicatus and Dichotomius rafanunezi sp. nov.) where they are trituberculate; pronotum without ornamentation, displaying at most a truncate declivity or knob; pronotum convex in females.

\section{Redescription}

Large to medium-sized species (length: 11-28 mm). Body in most cases shiny black to brownish, rarely copper coloured (as in D. subaeneus), dark blue (as in D. fornicatus) or dull green (as in Dichotomius rafanunezi sp. nov.).

HEAD. Wider than long, anterior clypeal margin emarginate (V-shaped when seen from above), producing short, rounded, subtriangular clypeal teeth, in some species clypeal teeth acute (as in D. inachoides) or reduced (as in D. belus). Male head process (over the front-clypeal suture) consisting of transverse trituberculate carina (here referred to as the cephalic carina), medial tubercle clearly higher than lateral ones (Fig. 1A-D) or very slightly higher (as in D. subaeneus). Clypeo-genal suture distinct and clypeogenal junction feebly emarginate. Genal border roundly expanded or even lobed posterior to clypeogenal suture.

Pronotum. Generally presenting a truncate slope or declivity on anterior portion, except for $D$. subaeneus which is convex. Hypomeral medial disc smooth (Fig. 2E as in amplicollis) or punctate (Fig. 2F as in D. tristis), lateral margins displaying single or multiple rows of long setae.

ABDOMEN. Metepisternum covered by ocellate setigerous punctures, upper posterior margin with subtriangular projection reaching the pseudoepipleuron. Metasternal medial disc smooth, lateral edges with dense pilosity (as in $D$. inachoides, $D$. deyrollei, $D$. validipilosus and $D$. simplicicornis) or dispersed pilosity (as in $D$. belus and $D$. subaeneus). Anterior portion near meso- and metasternal suture punctate, covered by long setae or not. Medial edges of sternites shiny, smooth or with single row of punctures; lateral portions exhibiting dense ocellate punctures. Male sixth sternite narrowed medially.

Legs. Metacoxa displaying single (as in D. agenor) or two rows of setae. Protibia calcar generally spiniform except apically bifurcate in $D$. belus and D. subaeneus.

SeXual Dimorphism. Smaller or less developed males of D. agenor species group have cephalic carina less developed or, as in females, bearing two tubercles. Females have larger clypeal teeth with deeper emargination, denser and longer pilosity, pronotal disc bearing deeper and denser punctures. Female 
cephalic carina bi- or quadrituberculate (Fig. 1E-F), except for D. fornicatus and D. rafanunezi sp. nov., in which is trituberculate. Female sixth abdominal sternite twice as wide in the middle as in males and not narrowed medially.

\section{Distribution}

The distribution of the Dichotomius (L.) agenor species group is broad, from the north Pacific coast of Mexico (Sonora desert) to the central region of South America (Argentina: Santiago del Estero, Brazil: Mato Grosso state). Altitudinal range is variable, from nearly 3000 metres in the Andes mountain range to sea-level at the Atlantic or Pacific coast.
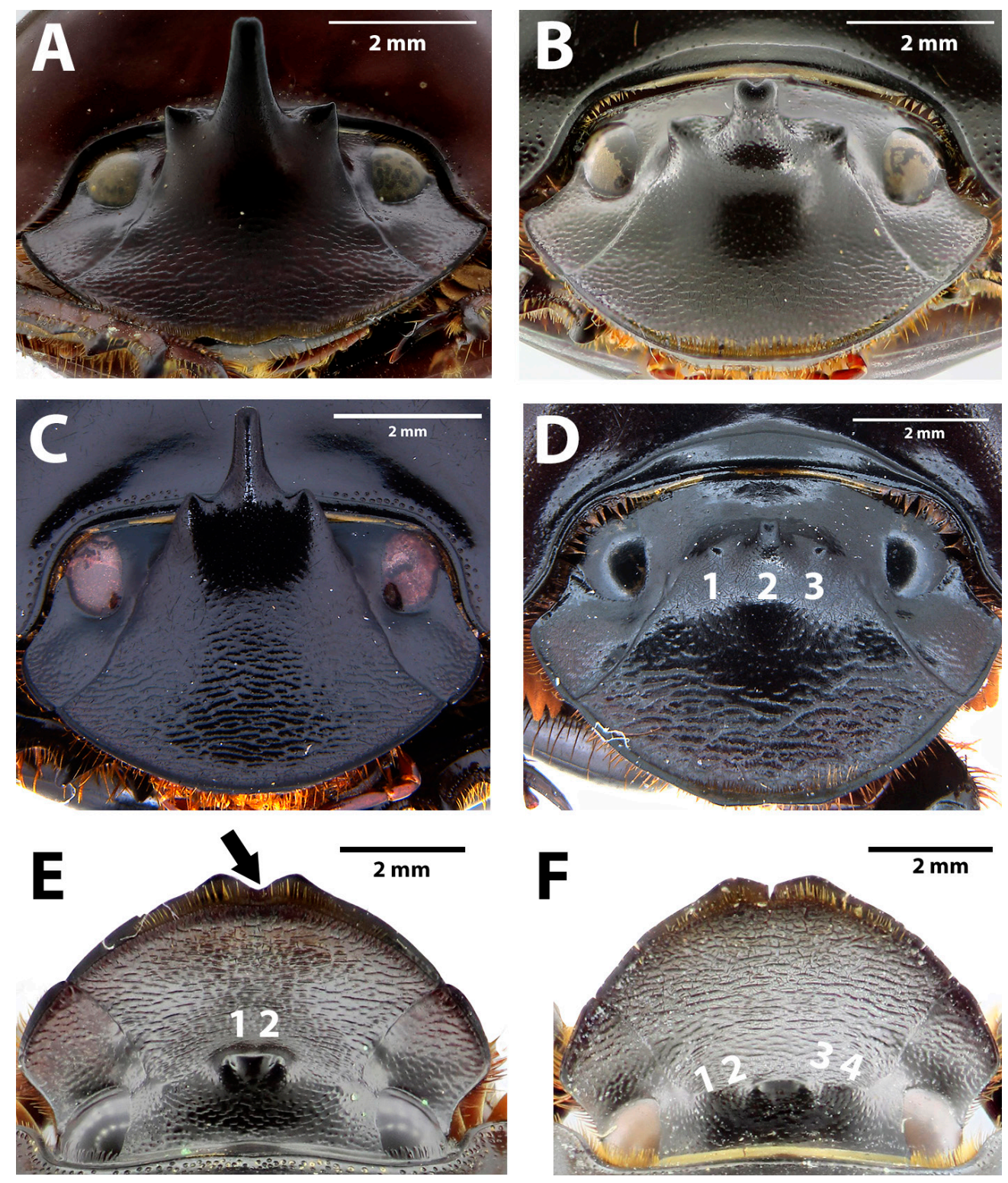

Fig. 1. Diagnostic characters of the Dichotomius (Luederwaldtinia) agenor species group. A-D. Male diverse trituberculate fronto-clypeal carina shapes. A. D. tristis (Luederwaldt, 1923). B. D. amplicollis (Harold, 1869). C. D. belus (Harold, 1880). D. D. validipilosus (Luederwaldt, 1931). E-F. Female fronto-clypeal carina. E. Bituberculate carina typical of $D$. tristis. F. Quadrituberculate carina typical of D. amplicollis. 

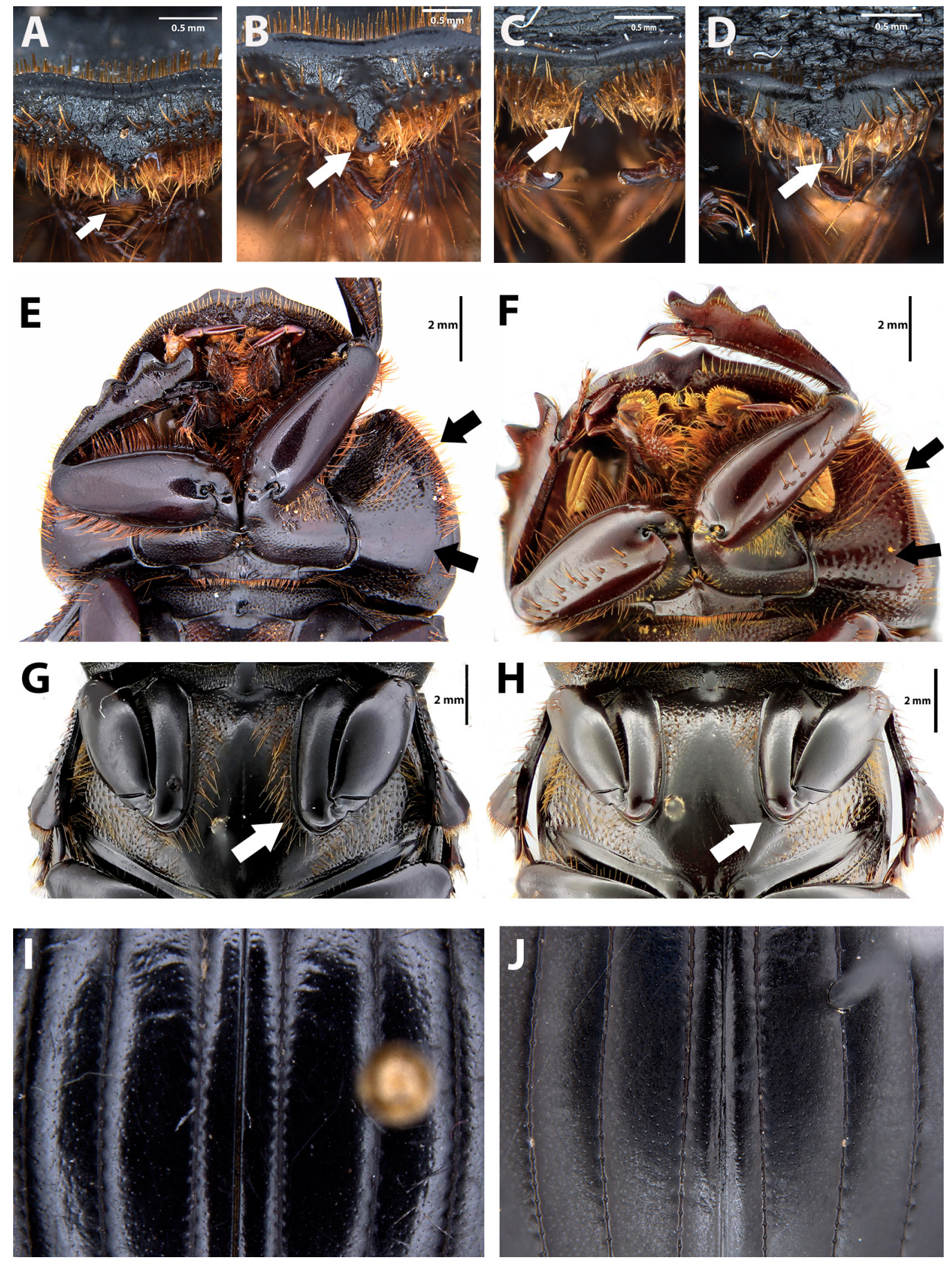

Fig. 2. General characters that help differentiate the species of the Dichotomius (Luederwaldtinia) agenor species group. A-D. Ventral clypeal process. A. Cordate as in D. agenor (Harold, 1869). B. Truncate as in D. sagittarius (Harold, 1869) stat. rev. C. Bifurcate as in D. belus (Harold, 1880). D. Cylindrical as in D. henripittieri sp. nov. E-F. Hypomeral characters. E. Medial disc smooth, lateral margin with multiple rows of setae as in D. amplicollis (Harold, 1869). F. Medial disc punctate, lateral margin with single row of setae as in D. tristis (Luederwaldt, 1923). G-H. Metasternum characters. G. Setigerous punctures from the medial and lateral edges joining throughout the margin of the mesocaxa as in D. enioi sp. nov. H. Setigerous punctures from the medial and lateral edges not joining throughout the margin of the mesocaxa as in D. centralis (Harold, 1869). I-J. Elytra interstriae. I. Smooth as in D. amplicollis. J. Shagreened as in D. agenor. 
Identification key to the species of the Dichotomius agenor species group based on male characters

1. Dorsally shining coppery, sometimes with green reflections. Large males with cephalic carina narrow, wider than high (Brazil, Trinidad and Guyana)..Dichotomius subaeneus (Castelnau, 1840)

- Dorsally black, brown or dull dark blue, or if metallic green then size less than $15 \mathrm{~mm}$. Large males with cephalic carina conspicuous

2. Dorsally shining green except for the elytra which are opaque. Cephalic carina undeveloped, narrow. (Anterior edge of the metasternum rugose.) Sixth abdominal sternite and pygidium lower, more depressed than the other sternites. Body length less than $15 \mathrm{~mm}$. (Brazil: Mato Grosso).

Dichotomius rafanunezi sp. nov.

- Dorsally generally black or at most dull dark blue. Cephalic carina well developed, conspicuous. Sixth abdominal and pygidium as high as the other sternites. Body length greater than $15 \mathrm{~mm}$, except for D. fornicatus (dark blue)

3. Pronotum surface subrugose. Elytral striae crenulate (Costa Rica, Guatemala and Nicaragua) .......... D. centralis (Harold, 1869)

- Pronotum with punctures, never rugose. Elytral striae not crenulate..... 4

4. Metasternum lateral edges smooth, except for minute setae arising from the centre of each ocellate puncture. Cephalic carina antero-posteriorly flattened, medial tubercle acute distally, never apically expanded or emarginate medially. Pronotum gibbous, smooth and shiny. Body pilosity spare or absent. (Colombia)......

D. belus (Harold, 1880)

- Metasternum lateral edges usually covered by long/large setae, if smooth then body length less than $15 \mathrm{~mm}$. Cephalic carina not flattened, medial tubercle not acute distally and in some species apically emarginate. Pronotum with small knob, with well-defined punctures. Body pilosity dense.............. 5

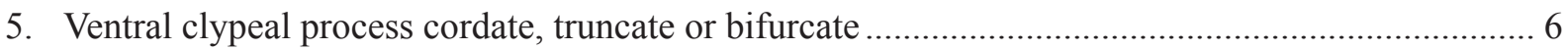

- Ventral clypeal process cylindrical, never cordate, truncate or bifurcate ........................................... 7

6. Metasternum with dense pilosity that conceals the metepisternal suture ....................................... 8

- Metasternum without dense pilosity, metepisternal suture clearly visible .......................................11

7. Cephalic carina distinctly arcuate in dorsal view. Pronotum with abrupt anterior declivity when viewed laterally, middle surface deeper than lateral, displaying two well-developed lobes on the anteromedial edge. (Interocular space with scattered simple punctures.) Dark blue to black. Body length less than $15 \mathrm{~mm}$. (Argentina, Bolivia and Paraguay) .........D. fornicatus (Luederwaldt, 1931)

- Cephalic carina transverse. Pronotum with smooth declivity, not modified anteriorly. Dense ocellate punctures covering the surface next to the eyes. Black to dark brown. Body length greater than $15 \mathrm{~mm}$. (Venezuela) Dichotomius henripittieri sp. nov.

8. Cephalic carina antero-posteriorly flattened, trituberculate, inclined anteriorly, apically expanded and emarginate medially. Anterior edge of the declivity medial area deeper and more convex than lateral ones (Colombia and Venezuela) .....

D. deyrollei (Harold, 1869)

- Cephalic carina conical, not antero-posteriorly flattened neither inclined anteriorly. Anterior edge of the pronotum modified, not convex, displaying undeveloped lobes

9. Pronotum with three undeveloped lobes on the anterior edge. Cephalic carina with lateral tubercles indistinct, medial tubercle with an acute apex, never emarginate. (Clypeus with a tooth or protuberance before the clypeogenal junction.) (Colombia and Venezuela).

D. inachoides (Felsche, 1901)

- Pronotum with two underdeveloped lobes on the anterior edge. Cephalic carina with defined lateral tubercles, medial tubercle emarginate at apex 
10. Clypeus not rounded. Head with anterior third surface subrugose. Pronotum as wide as the elytra, surface smooth, with ocellate punctation on the posterior margin. (Venezuela).

D. validipilosus (Luederwaldt, 1931)

- Clypeus rounded. Head anterior third transversally rugose. Pronotum wider than the elytra, posterior margin without ocellate punctation, punctation sparse if present. (Peru).

D. simplicicornis (Luederwaldt, 1935)

11. Setigerous punctures of the medial and lateral edges of the metasternum connected via the inner mesocoxal margins (Fig. 2G). Pronotal anterior declivity with a medial subemargination ............ 12

- Setigerous punctures of the medial and lateral edges of the metasternum not connected via the inner mesocoxal margins (Fig. 2H). Pronotal anterior declivity without medial subemargination.....

12. Male median tubercle of the cephalic carina thick, cylindrical and with a pronounced apical emargination. Metacoxae posterior edge bearing row of organized, shallow ocellate setigerous punctures which merge together (Fig. 4H) (Mexico) .

D. amplicollis (Harold, 1869)

- Male median tubercle of the cephalic carina not cylindrical, apex feebly emarginate or rounded. Metacoxae posterior edge bearing row of organized, ocellate setigerous punctures not merging together (Figs 11E and 12E).....

13. Interocular space smooth with fine rounded punctures. Male median tubercle of the cephalic carina not emarginate apically (Fig. 11D). Pronotum surface covered by fine punctures, margins with row of dense interrupted ocellate punctures. Female pronotum surface smooth with fine punctures (Mexico) D. sagittarius (Harold, 1869) stat. rev.

- Interocular space covered by shagreened microsculpture and flat punctation. Male median tubercle of the cephalic carina feebly emarginate apically. Pronotum surface covered by well-impressed simple punctures, margins with row of dense uninterrupted ocellate punctures. Female pronotum covered with dense and deeply impressed punctures (Costa Rica, Guatemala and Mexico)... D. enioi sp. nov.

14. Median tubercle of the cephalic carina apically emarginate. Lateral margin of the hypomera with multiple rows of setae (Fig. 2E). Metacoxa with more than one row of punctures on the posterior margin (Colombia, Panamá and Venezuela).

D. agenor (Harold, 1869)

- Median tubercle of the cephalic carina not apically emarginate. Lateral margin of the hypomera with single row of setae. Metacoxa with single row of punctures on the posterior margin

15. Dorsal and ventral surface black. Clypeus with weak central emargination. Anterior portion of the pronotum with a strong, abrupt declivity. Median tubercle of the cephalic carina approximately two and a half times as high as lateral tubercles. Punctures of the lateral edges of the metasternum separated by three times the puncture diameter (Fig. 2). (Colombia and Venezuela)

D. tristis (Luederwaldt, 1923)

- Dorsal and ventral surface dark brown. Clypeus with deep central emargination separating two obtuse teeth. Median tubercle of the cephalic carina twice as high as lateral tubercles. Punctures of the lateral edges of the metasternum separated by one puncture diameter (Trinidad) D. triquetrus (Luederwaldt, 1923)

\section{Species catalogue and descriptions}

Genus Dichotomius Hope, 1838

Dichotomius (Luederwaldtinia) agenor (Harold, 1869)

Fig. 3, Map 1

Pinotus agenor Harold, 1869: 141 (original description). 
Pinotus agenor - Luederwaldt 1929: 99. — Blackwelder 1944: 69.

Dichotomius agenor - Howden \& Young 1981: 13. — Medina et al. 2001: 138. — Ratcliffe 2002: 15

— Sarmiento \& Amat 2014: 89-90.

\section{Diagnosis}

Dichotomius agenor is separated from the other species in the group by the following combination of characters: large male fronto-clypeal carina with lower part wider than high, with median tubercle bifurcate apically, concave between central and lateral tubercles. Pronotum with pronounced, truncate anterior declivity, when viewed laterally. External margin of hypomeron bearing multiple rows of disorganized long setae, all approximately the same length, that can be seen in dorsal view. Posterior edge of metacoxa bearing two rows of disorganized ocellate punctures, separated by half the diameter of a puncture.

\section{Material examined}

Lectotype (here designated)

COLOMBIA • O'; "Columbia. P Agenor" [white with red margins, hw]/ "Ex-Musaeo E.Harold" [white with black margins, p]/ "LECTOTYPE $\widehat{\top}$ Pinotus agenor Harold des. F.Z. Vaz-de-Mello, 2014" [red with black margin, phw]; MNHN.

Paralectotypes $(1 \hat{O}, 1$ q)

COLOMBIA • 1 กै; "Agenor Colomb." [white, hw]/ "Ex-Musaeo E. Harold" [white with black margins, p]/ “ § Pinotus agenor Harold des. F.Z. Vaz-de-Mello, 2014” [yellow with black margin, phw]; MNHN • 1 ㅇ; "Agenor Colomb." [white, hw]/ "Ex-Musaeo E. Harold” [white with black margins, p]/ “ $q$ Pinotus agenor Harold des. F.Z. Vaz-de-Mello, 2014” [yellow with black margin, phw]; MNHN.

\section{Additional material}

COLOMBIA - Antioquia - 1 spec.; Sonsón, San Miguel, Fca. La Rica; 160-250 m a.s.1.; 21 Aug. 2006; J. Arias leg.; IAvH • 1 đ̃ ; Antioquia; BMNH 5438. - Atlántico • 1 spec.; Juan de Acosta, tierra

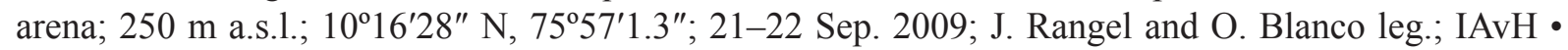

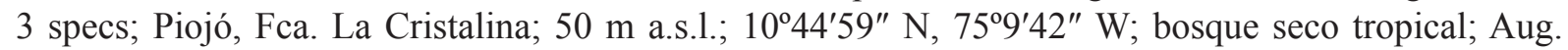
2015; A. Lopera and N. Castillo leg.; IAvH • 1 spec.; Piojó, Fca. La Cristalina; 50 m a.s.1.; 1044'59" N, 75 ${ }^{\circ}$ '42" W; bosque seco tropical; Aug. 2015; A. Lopera and N. Castillo leg.; ECC. - Bolivar - 1 spec.; Isla de Tierra Bomba; 100 m a.s.1.; 10²1'36" N, 75³4'30" W; Aug. 1996; F. Escobar leg.; ECC • 9 specs.; San Juan de Nepomuceno, Fca. Mis Deseos; 482 m a.s.1.; 955'8.4" N, 75'9'33.7" W; bosque seco tropical; Aug. 2015; A. Lopera and N. Castillo leg.; IAvH • 1 spec.; San Juan de Nepomuceno, Fca. Mis Deseos; 482 m a.s.1.; $9^{\circ} 55^{\prime} 8.4^{\prime \prime}$ N, 75 $5^{\circ} 33.7^{\prime \prime}$ W; bosque seco tropical; Aug. 2015; A. Lopera and N. Castillo leg.; ECC • 1 spec.; Zambrano, Had. Moterrey; 120 m a.s.1.; 9 $37^{\prime} 48^{\prime \prime}$ N, 7454'44" W; Aug. 1996;

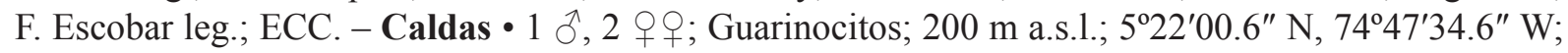
Aug. 2015; S. Montoya-M. leg.; CEMT • 1 क; Norcasia, Vda. San Roque-Reserva Rio Natural Manso; 220 m a.s.1.; 5039'40" N, 7446 ${ }^{\prime} 98^{\prime \prime}$ W; bosque; 1 Aug. 2004; L. Arango and A. Montes leg.; ECC. Caquetá - 1 đ̃; Yari; 16 Oct. 1986; CEMT. - Cesar - 110 specs; Codazzi; 165 m a.s.1.; 958'42" N, 73 56'44" W; 17 May 2016; C. Giraldo and A. León, J leg.; MUSENUV • 1 spec.; Valledupar; 160 m a.s.1.; $10^{\circ} 21.747^{\prime}$ N, 73²3.26' W; Potrero; Aug. 2013; S. Montoya leg.; ECC • 1 spec.; Velledupar,

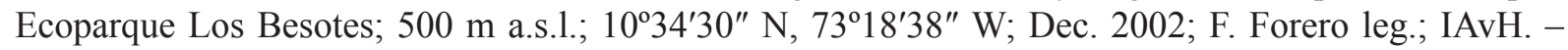
Cordoba • 1 spec.; Monteria, Las Palmeras; 8³0'37.1" N, 76²6'12.9" W; bosque; Sep. 2011 spec.; A. Vargas-Pérez leg.; ECC • 1 spec.; Monteria, Vda. Sierra Chiquita; 125 m a.s.1.; 844'22" N, 7554'40" W; bosque seco tropical; Dec. 2011 spec.; R. Leidys Murillo leg.; ECC • 8 specs; Monteria, Vda. Sierra

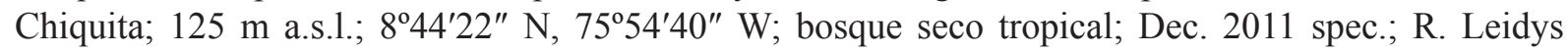
Murillo leg.; IAvH • 1 spec.; Tierra Alta, Vereda Tuis-Tuis, Reserva Tuis-Tuis; 125 m a.s.1.; 8²'23.7" N, 765'59.6" W; Apr. 2011 spec.; R. Leidys Murillo leg.; ECC. - Cundinamarca • 2 q o ; San Juan de Rio 
Seco; bosque seco tropical; 1300 m a.s.1.; 12 Oct. 1997; Pulido-Riveros leg.; ECC • 2 specs; Bogotá; Nevinson leg.; BMNH 1918-14. - Huila - 7 specs; Desierto de la Tatacoa; 480 m a.s.1.; $3^{\circ} 13^{\prime} 50^{\prime \prime} \mathrm{N}$, 75ㅇ'25" W; Nov. 2012; D. Martínez leg.; IAvH. - La Guajira • 252 specs; Jagua del Pilar; 181 m a.s.l.; $10^{\circ} 30.88^{\prime}$ N, 73⒌31' W; Aug. 2013; S. Montoya leg.; IAvH • 282 specs; Uribia, PNN La MacuiraCorregimiento de Nazareth Kajashiwou; 70 m a.s.1.; $12^{\circ} 11^{\prime} 37^{\prime \prime} \mathrm{N}, 71^{\circ} 21^{\prime} 30^{\prime \prime} \mathrm{W}$; bosque seco tropical; 19 May 2014; C. Medina and A. González leg.; IAvH. - Magdalena • 1 spec.; Santa Marta, PNN Sierra Nevada, C. Minca, Cuenca del rio Gaira, Sector Pozo Azúl; 740 m a.s.1.; 11 $8^{\circ} 17^{\prime \prime}$ N, 74 $4^{\circ}$ '29" W; 1-2 Aug. 2004; H. García and D. Ospino leg.; ECC • 1 spec.; Santa Marta, PNN Sierra Nevada; C.

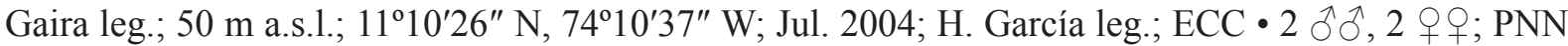
Tayrona Neguanje; $155 \mathrm{~m}$ a.s.1.; $11^{\circ} 17^{\prime} 41^{\prime \prime} \mathrm{N}, 7^{\circ} 06^{\prime} 15^{\prime \prime} \mathrm{W}$; bosque seco excr. humano; Sep. 1996; F.

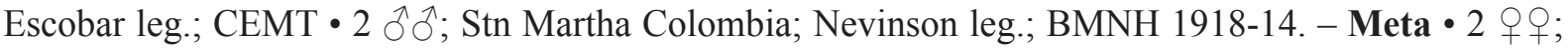
Santander, Encino, Sector La Gorda, Finca San Agustín; Pastizal; 2000 m a.s.1.; trampa de excremento humano; Dec. 2009; J. Arias-Buriticá leg.; CEMT. - Sucre • 94 specs; San Benito Abad, Vda. Santiago Apostol; 30 m a.s.1.; 9 2'19" N, 7554'25" W; Palmar leg.; Oct. 2009; L.E. Franco leg.; IAvH • 1 spec.; San Benito Abad, Vda. Santiago Apostol; 30 m a.s.1.; 9²'19" N, 7554'25" W; Palmar leg.; Oct. 2009; L.E. Franco; ECC -3 specs; Colosó, Montes de María, Sector La Cascada, Estación Primatológica; 28-30 Apr. 2009; L.E. Franco leg.; IAvH. - Tolima - 20 specs; Alvarado, Fca. La Brasilia; 537 m a.s.l.; 5¹1'34" N, 75³9'33" W; 7 Mar. 2016; C. Giraldo and A. León J leg.; MUSENUV • 1 §’; Armero; bosque; 260 m a.s.1.; Nov. 2000; J. Noriega leg.; CEMT•1 万’; Guayabal. Armero. Oct. 2000; J. Noriega leg.; CEMT • 1 क; Armero, Cerros de Santo Tomás; 250 m a.s.l.; Nov. 2000; J. Noriega leg.; CEMT • 1 spec.;

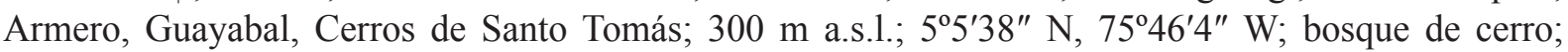
Nov. 1995; F. Escobar leg.; ECC • 183 specs; Armero, Guayabal, Cerros de Santo Tomás; 300 m a.s.l.; 55'38" N, 7546'4" W; bosque de cerro; Nov. 1995; F. Escobar leg.; IAvH • 1 O’; Armero, Guayabal, Mendez Had. Cardonal; 300 m a.s.1.; 505'38" N, 7446'39" W; excr. humano; Borde Bo-Po [border between forest-pasture]; Sep. 1995; F. Escobar leg.; CEMT • 45 specs; Armero, Guayabal, Mendez Had. Cardonal; 300 m a.s.l.; 55'38" N, 7446'39" W; excr. humano; Borde Bo-Po; Sep. 1995; F. Escobar leg.; IAvH • 1 q; Armero, Guayabal Mendez Had. Bremen; 300 m a.s.1.; 5'5'31" N, 7445'81" W; excr. humano; Nov. 1995; F. Escobar leg.; CEMT • 116 specs; Armero, Guayabal Mendez Had. Bremen; 300 m a.s.1.; 5'5'31" N, 7445'81" W; excr. humano; Nov. 1995; F. Escobar leg.; IAvH. - Valle del Cauca • 1 spec.; Buga, Fca. Los Chagualos; 29 Feb. 2016; C. Giraldo and A. León, J; MUSENUV • 1 ; ; Colombia, Nevinson leg.; BMNH 1918-14.

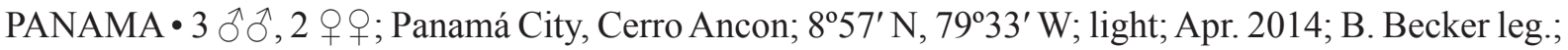
CEMT 1 ỡ; La Chorrera, Panamá; BMNH 98-146.

VENEZUELA - Mérida • 4 $\widehat{\partial}, 4$ q + ; Libertador, Meseta de Zumba, Had. Los Arcos; $1181 \mathrm{~m}$ a.s.1.; $8^{\circ} 33^{\prime} 14^{\prime \prime} \mathrm{N}, 71^{\circ} 13^{\prime} 20^{\prime \prime} \mathrm{W}$; pitfall human faeces; 6 May 2016; R. Acconcia and J. Gámez leg.; CEMT •

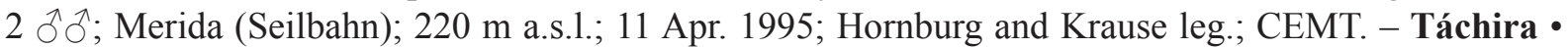

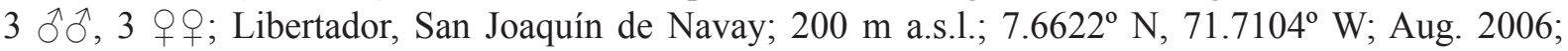
T. Good leg.; CEMT. - Yaracuy • 1 q; Bolivar Aroa; $468 \mathrm{~m}$ a.s.1.; $10^{\circ} 0^{\prime} 0^{\prime \prime} \mathrm{N}, 68^{\circ} 0^{\prime} 0^{\prime \prime} \mathrm{W}$; heces humanas; 21 Jul. 2009; M. Asmüssen, P. Colmenares and H. Martínez leg.; CEMT • $2 \widehat{\jmath}, 4$ + $\odot$; Venez [Venezuela]; Nevinson leg. BMNH 1918-14 • 2 ठえ

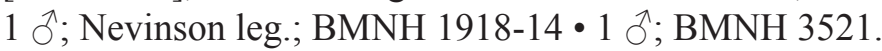

\section{Redescription}

\section{Male}

MeAsurements. Length: $20.5 \mathrm{~mm}$.

HEAD. Anterior surface rugose, not extending posteriorly to base of cephalic carina. Cephalic carina wider than high, anterior surface smooth, dorsally concave between central and lateral tubercles (Fig. 3C); 

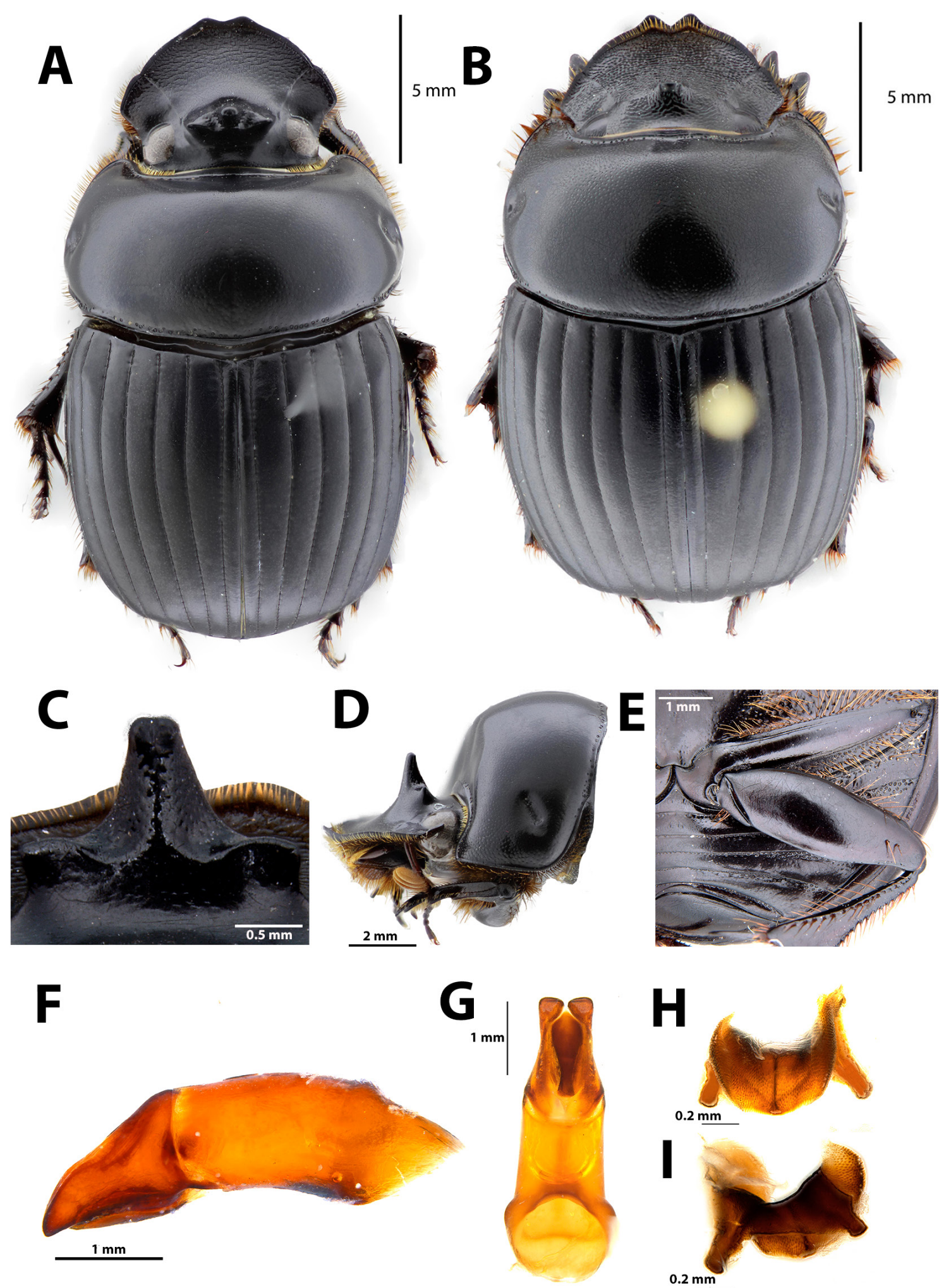

Fig. 3. Dichotomius agenor (Harold, 1869). A-B. Dorsal habitus. A. ڤ̊. B. . . C. Posterior view of the cephalic carina, concavity between the central and the lateral tubercles, apically emarginate. D. Lateral view of the pronotum, anterior declivity truncate. E. Ventral view of the metacoxa, displaying two rows of punctures on the posterior margin. F. Lateral view of the aedeagus. G. Ventral view of the aedeagus. H-I. Lamella copulatrix. 
median tubercle twice as high as lateral tubercles, conical in shape and apically emarginate. Interocular space shiny, smooth. Ventral clypeal process cordate (see Fig. 2A).

Pronotum. Wider than long and wider than elytra. Pronotal disc shiny and smooth, lacking deep punctures, with at most fine punctures. Anterior declivity pronounced and truncate when viewed laterally (Fig. 3D). Ocellate punctures present along anterior and posterior margins, few scattered ocellate punctures in lateral margins (Fig. 3A). Hypomeron medial disc punctures separated by three times the width of a puncture. External margin bearing multiple rows of disorganized long setae (see Fig. 2E).

ABDOMEN. Mesosternum and metepisternum fully covered by ocellate setigerous punctures, pilosity dense, setae all of same length. Metasternum setigerous punctures restricted mainly to lateral and anterior areas. Anterior lobe pilosity never connecting with lateral pilosity through margin of mesocoxae (see Fig. 2H). Lateral surface with ocellate setigerous punctures separated by twice the width of a puncture, variation in puncture diameter almost imperceptible. Ocellate punctation along anterolateral margins of sternites. Pygidium surface covered by small, fine punctures. Basal margin bearing few ocellate punctures.

ElytRA. Interstriae shagreened, with fine, randomly separated punctures with interior shagreened microsculpture. Striae hardly marked, with ocellate punctures separated by twice the diameter of a puncture on elytral disc (see Fig. 2J).

LEgs. Metacoxa posterior edge bearing two contiguous rows of organized ocellate punctures, separated by half the diameter of a puncture (Fig. 3E).

Parameres and lamella copulatrix of aedeagus. As in Fig. 3F-H.

\section{Morphological variation}

Females (Fig. 3B)

As males except for the following characters:

Head. Completely transversely rugose, denser on anterior portion. Cephalic carina bituberculate (see Fig. 1E).

Pronotum. Weak medial knob, only detectable in lateral view. Hypomeron setae longer and denser than in males.

\section{Remarks}

Luederwaldt (1929) placed this species in the assifer section which included species from the assifer and agenor groups. Harold's type material was from Colombia, but the label does not specify the exact locality. This species is known to occur in Panama, Colombia and Venezuela from 100 to $1500 \mathrm{~m}$ a.s.l., in the Caribbean subregion as proposed by Morrone (2001). It is found in the Magdalena and Maracaibo Provinces, associated with dry and humid forests (Morrone 2001). Individuals of this species are easily confused with D. enioi sp. nov., a Central American species.

Dichotomius (Luederwaldtinia) amplicollis (Harold, 1869)

Fig. 4, Map 2

Pinotus amplicollis Harold, 1869: 501 (original description).

Pinotus amplicollis - Blackwelder 1944: 69.

Dichotomius amplicollis - López-Guerrero 2005: 196. 


\section{Diagnosis}

Dichotomius amplicollis is separated from other species of the group by the following combination of characters: median tubercle of the fronto-clypeal carina twice as high as the two lateral tubercles, thick, cylindrical and with pronounced apical median emargination. Posterior surface of cephalic carina rugose. Anterior edge of pronotum with strong, abrupt declivity, apex with weak anteromedian lobe bifurcation. Posterior edge of metacoxa bearing a single row of organized, shallow ocellate setigerous punctures which merge together.

\section{Material examined}

Lectotype (here designated)

MEXICO - O'; "Oaxaca P. amplicollis." [white with red margins, hw]/ "Mexico amplicollis Harold" [white, hw]/“LECTOTYPE § Pinotus amplicollis Harold des. F.Z. Vaz-de-Mello, 2014” [red with black margin, phw]; MNHN.

\section{Paralectotype}

MEXICO • 1 ; "Sallé". "P. amplicollis mihi. $\odot "$ [hw, Harold's handwriting]/ "PARALECTOTYPE +Pinotus amplicollis Harold des. F.Z. Vaz-de-Mello, 2014" [yellow with black margin, phw]; MNHN.

\section{Additional material}

MEXICO - Chihuahua - 1 ô, 1 क; Pinos Altos; Buchan-Hepburn. B.C.A; p.52. sp.2; BMNH. -

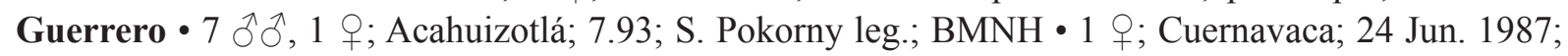

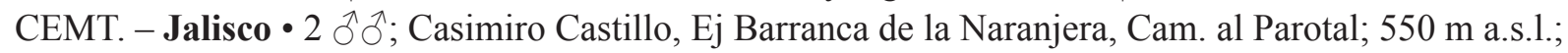

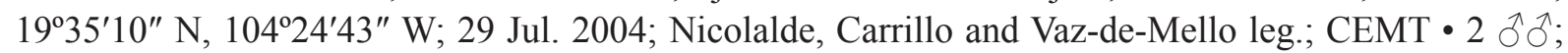

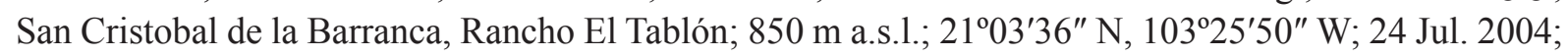

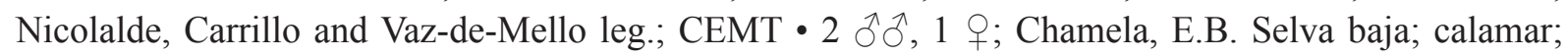
Jul. 2002; Ellen Andersen leg.; CEMT • 1 §, 1 क; Unión de Tula, Km 131 Carr. Guadalajara-Barra de Navidad; 1110 m a.s.1.; 1952'46" N, 104'18'58" W; 30 Jul. 2004; Nicolalde, Carrillo and Vaz-deMello leg.; CEMT • 1 \&; Tonaya, Las Higueras, Jardín de Casa; 950 m a.s.l.; T. luz mercurial; Aug. 2004.

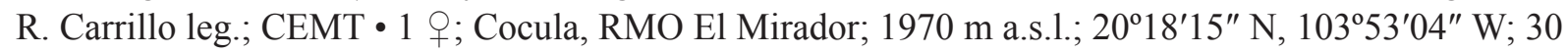
Jul. 2004; Nicolalde, Carrillo and Vaz-de-Mello leg.; CEMT • 2 + ; Zapopan, Los Guayabos, BE.pert; 1600 m a.s.1.; exNTP-80 pulpo; 11 Jun.-8 Jul. 1994; G.A. Quiroz and J.L. Navarrete leg.; CEMT • 1 क ; Ventanas, Mex; $200 \mathrm{ft}$ a.s.1.; Forter. B.C.A. p.52. sp.2; MNHN. - Mexico • 1 đ; Temascaltepec; Hinton Coll. B.M; BMNH 1939-583 • 4 ỗ, 8 o 0 ; Real de Arriba, Temascaltepec; 1933; Hinton Coll. B.M; BMNH 1939-583 • 2 ふ઼े, 1 ค; Bejucos, Temascaltepec; 1933; Hinton Coll. B.M; BMNH 1939-583 • 1 †; Tejupilco, Temascaltepec; 1933; Hinton Coll. B.M; BMNH 1939-583. - Sonora • 1 đ , 1 q; La Estrella; 10-32; Hinton Coll. B.M; BMNH 1939-583 - 2 qo ; Alamos; Buchan-Hepburn, B.C.A; p.52.

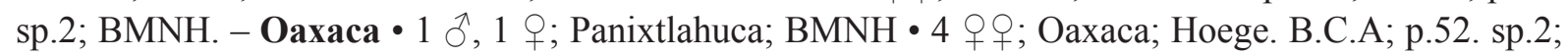
$\mathrm{BMNH}$.

\section{Redescription}

Male

MEASUREMENTs. Length: $21.7 \mathrm{~mm}$.

HEAD. Anterior surface rugose, not extending posteriorly to base of cephalic carina. Cephalic carina wider than high, posterior surface covered with deep punctures. Median tubercle twice as high as lateral tubercles, thick, cylindrical in shape and with strong apical emargination. Lateral tubercles with acute apex (Fig. 4D). Ventral clypeal process truncate and distally expanded. 

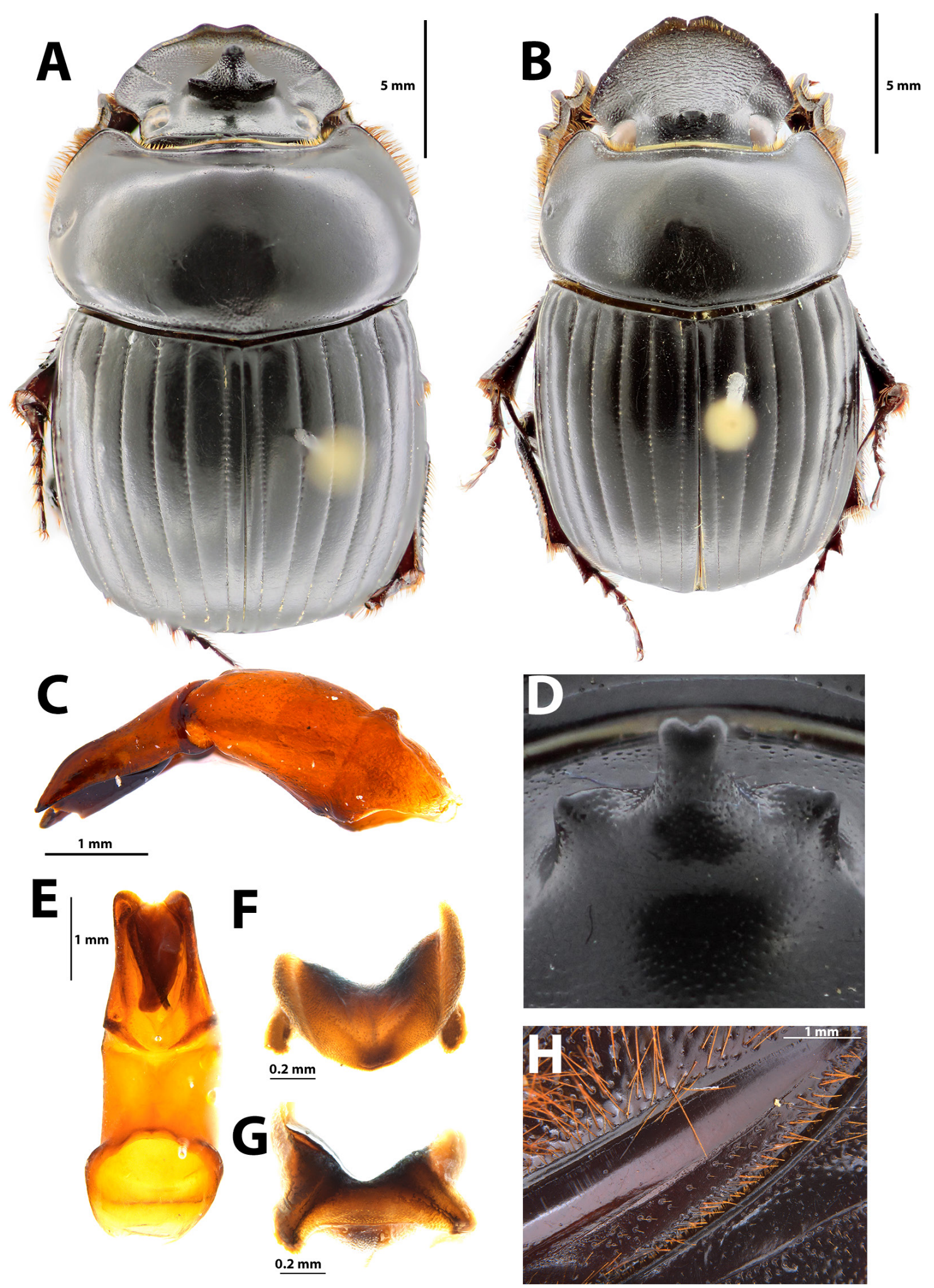

Fig. 4. Dichotomius amplicollis (Harold, 1869). A-B. Dorsal habitus. A. O. B. ๆ. C. Lateral view of the aedeagus. D. Anterior view of the cephalic carina, the central tubercle cylindrical and apically emarginate. E. Ventral view of the aedeagus. F-G. Lamella copulatrix. H. Ventral view of the metacoxa, displaying a single row of organized ocellate setigerous punctures which merge together on the posterior margin. 
Pronotum. Wider than long, wider than elytra. Pronotal disc shiny, with smooth fine punctures. Anterior edge with pronounced declivity well-impressed punctures covering surface. Longitudinal sulcus weakly impressed, producing weak anteromedian lobe subemargination (as in Harold 1869); anterolateral surface with dense-impressed punctures next to antero-lateral fossae. Posteromedial edge with few dense and weakly impressed punctures near medial sulcus. Scattered ocellate punctures along anterior and posterior margins, absent in lateral margins (Fig. 4A). Hypomeron medial disc smooth. External margin bearing multiple rows of disorganized long setae (see Fig. 2E).

ABdomen. Mesosternum and metepisternum covered by large ocellate setigerous punctures, setae short. Metasternum setigerous punctures restricted to anterior and lateral areas. Anterior lobe pilosity connecting with lateral through margin of mesocoxa (see Fig. 2G). Lateral surface of metasternum with ocellate setigerous punctures separated by diameter of a puncture, setae long. Longitudinal sulcus conspicuous. Ocellate punctures along anterior margin of each sternite, denser in lateral areas, medial portion smooth. Pygidium surface smooth. Basal margin bearing some ocellate punctures.

ELYTRA. Interstriae shagreened with fine randomly separated punctures. Striae strongly marked, crenulate, ocellate punctures separated by diameter of a puncture on elytral disc (see Fig. 2I).

Legs. Posterior metacoxa edge bearing row of organized, shallow ocellate setigerous punctures which merge together (Fig. 4H).

Parameres And lamella copulatrix. As in Fig. 4E-G.

\section{Morphological variation}

\section{Females (Fig. 4B)}

As males except for the following characters:

HEAD. Completely transversely rugose, denser on anterior apical third. Fronto-clypeal carina quadridentate and greatly elevated, median tubercles higher than lateral.

Pronotum. Weak medial knob, discernible in lateral view, punctures dense and deeply impressed on lateral areas and near posterior margin of medial sulcus.

Hypomeron. Setae longer and denser than in males.

ELYTRA. Striae, thinner and with smaller, ocellate punctures separated by diameter of a puncture at elytral disc.

\section{Remarks}

Dichotomius amplicollis is associated with tropical dry forests and is distributed across the Mexican Pacific coast province (Morrone 2001) in the states of Oaxaca (type locality) and Jalisco from 500 to $1900 \mathrm{~m}$ a.s.l. It is highly probable that it is also found throughout the states of Sinaloa, Nayarit, Michoacan and Colima. Individuals of this species are commonly confused with D. sagittarius stat. rev., in which the middle tubercle is not apically emarginate and the punctures of the posterior edge of the metacoxa are not merged together. Other characters of the male genitalia also differ between these two species.

Dichotomius (Luederwaldtinia) belus (Harold, 1880)

Fig. 5, Map 3

Pinotus belus Harold, 1880: 25 (original description). 
Pinotus belus - Luederwaldt 1929: 98; 1936: 213. — Blackwelder 1944: 80.

Dichotomius belus - Roze 1955: 44. — Medina et al. 2001: 138. — Sarmiento \& Amat 2014: 93-95.

\section{Diagnosis}

Dichotomius belus is separated from other species in the group by the following combination of characters: setae on body surface sparse or absent. Clypeal teeth generally reduced in large males and in most cases completely absent in females. Male cephalic carina conical, antero-posteriorly flattened and curved anteriorly, higher than wide. Ventral clypeal process greatly emarginate.

\section{Material examined}

Lectotype (here designated)

COLOMBIA • Õ, "Medellín" [white, hw]/ "Belus Harold." [white, hw]/ "Ex-Musaeo E. Harold" [white with black margins, p]/ "LECTOTYPE ${ }^{1}$ Pinotus belus Harold des. F.Z. Vaz-de-Mello, 2014” [red with black margin, phw]; MNHN.

Paralectotypes $(3 \hat{\jmath} \hat{\jmath}, 3$ 우 $)$

COLOMBIA • 1 \&; "Columbia Pinotus Belus Harold" [white, hw]/"Ex-Musaeo E. Harold" [white with black margins, p] / "PARALECTOTYPE $Q$ Pinotus belus Harold des. F.Z. Vaz-de-Mello, 2014" [yellow

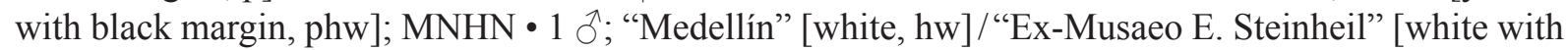
black margins, p]/ "PARALECTOTYPE ô Pinotus belus Harold des. F.Z. Vaz-de-Mello, 2014" [yellow with black margin, phw]; MNHN • 1 o; "Medellín" [white, hw]/“Ex-Musaeo E. Steinheil" [white with black margins, p]/ "PARALECTOTYPE + Pinotus belus Harold des. F.Z. Vaz-de-Mello, 2014" [yellow with black margin, phw]; MNHN • 1 O; "Medellín" [white, hw]/"Ex-Musaeo E. Steinheil" [white with black margins, p]/ "PARALECTOTYPE $q$ Pinotus belus Harold des. F.Z. Vaz-de-Mello, 2014" [yellow with black margin, phw]; MNHN • 1 ภे; "Ocaña Landoldt" [white, hw]/"Ex-Musaeo E. Steinheil" [white with black margins, p]/ "PARALECTOTYPE $\curvearrowright$ Pinotus belus Harold des. F.Z. Vaz-de-Mello, 2014" [yellow with black margin, phw]; MNHN • 1 万’; "Ambalema" [white, hw]/"ExMusaeo E. Steinheil" [white with black margins, p]/ "PARALECTOTYPE $\curvearrowright$ Pinotus belus Harold des. F.Z. Vaz-de-Mello, 2014" [yellow with black margin, phw]; MNHN.

\section{Additional material}

COLOMBIA • 1 ; ; 1-4 Mar. 1972; dung and forest; S. and J. Peck leg.; CEMT • 1 क; 22 Apr. 1964;

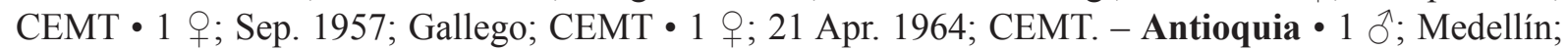
BMNH • 7 đิ ô, 5 oq ; Medellín; CEMT • 1 q; Medellín; 15 Dec. 1962; CEMT • 1 q; Medellín; Encorredo; Apr. 1947; Gallego leg.; CEMT • 6 ô ô, 1 क; Puerto Berrio; 300 m a.s.1.; 6²9'31.20" N, 74³4'39.84" W; Mar. 2015; S. Montoya-M leg.; CEMT • 3 specs; Puerto Berrio, Vda. La Carlota;

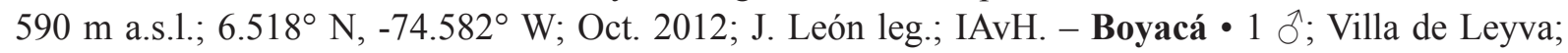
Pastizal; Dec. 1998; J. Noriega leg.; CEMT • 1 spec.; Villa de Leyva, Rio Cane; 2200 m a.s.1.; Jul. 1996; F. Escobar leg.; IAvH • 1 spec.; Villa de Leyva; 2200 m a.s.1.; Sep. 1996; M. Álvares leg.; IAvH] • 1 spec.; Villa de Leyva, Claustro San Agustín; 2200 m a.s.l.; Aug. 1998; K. Schutze leg.; IAvH. Cauca 1 spec.; Bolivar, Buenos Aires, Área de reserva Lerma; $1700 \mathrm{~m}$ a.s.1.; $2^{\circ} 0^{\prime} 0^{\prime \prime} \mathrm{N}, 7^{\circ} 57^{\prime} \mathrm{W}$; Jan. 2010; W. Guzmán leg.; ECC. - Cundinamarca • 1 spec.; Beltrán, Insp. Paquiló, Fca. Santana; 650 m a.s.1.; 4.6678 N, 74.7596 ${ }^{\circ}$ W; Nov. 2014; A. Lopera leg.; ECC • 1 spec.; Chinauta, Fusagasugá; 1900 m a.s.l.; Jan. 1995; A. Amézquita and A. Lopera leg.; ECC • 1 đ̊’ Fusagasugá; 6 Sep. 1962; CEMT • 1 q; Cachipay, alrededores colégio Fátima; 1500 m a.s.1.; 14 Apr. 1991; A. Mera and R. Lozano leg.; CEMT • 1 spec.; Juan de Rio Seco; 1300 m a.s.l.; Oct. 1997; H. Pulido-Riveros leg.; IAvH • 1 ડ๋; Bogotá; S9S2; BMNH. - Huila • 12 specs; Garzón, Vda. El Espinal; 1000 m a.s.1.; 2 $17^{\prime} 45^{\prime \prime}$ N,

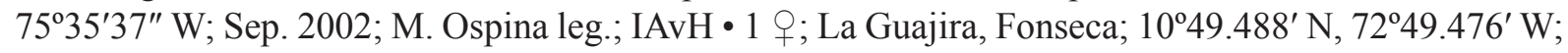
S. Montoya-M.leg.; CEMT. - Meta 1 § ; 33 Km E of Villavicencio; 2-4 Mar. 1972; S. and J. Peck; CEMT. - Nariño • 1 क ; Aguada; BMNH • $2 \hat{\jmath} \widehat{\jmath}, 1$ q ; Buesaco, RN El Charmolan, Vda. Hatotongosoy; 
2500 m a.s.1.; $1^{\circ} 22^{\prime} 38^{\prime \prime}$ N, $77^{\circ} 13^{\prime} 9^{\prime \prime}$ W; pitfall, Potrero Ganadero; 22-26 Aug. 2008; A.N.L. Hidalgo leg.; CEMT • 1 spec.; R.N. La Planada. 1800 m a.s.l.; Apr. 1994; F. Escobar leg.; IAvH • 7 specs; Taminango, Vda. Algodonal; $628 \mathrm{~m}$ a.s.1.; $1^{\circ} 40^{\prime} 6^{\prime \prime} \mathrm{N}, 7^{\circ} 17^{\prime} 15^{\prime \prime} \mathrm{W}$; Oct. 2013; J. Salazar and J. Castillo leg.; IAvH. - Quindío - 1 spec.; Córdoba, La Tribuna; 4²5'40" N, 75²0'22" W; Jul. 1999; J. Molina and J. Elejalde leg.; ECC. - Risaralda - 1 spec.; La Celia, Vda. La Secreta; 1720 m a.s.1.; 501'1.3" N,

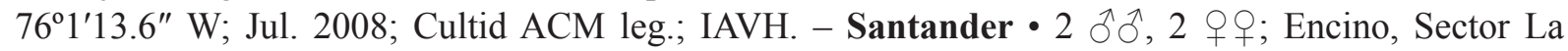
Gorda, Fca. San Agustín; 2000 m a.s.1.; 6 ${ }^{\circ} 7^{\prime} 12^{\prime \prime}$ N, $73^{\circ} 1^{\prime} 59^{\prime \prime}$ W; Pastizal; trampa de caída con excrement humano; 29 Nov.-1 Dec. 2009; J. Arias leg.; CEMT • 1 क; Santandercito; May 1960; CEMT • 1 spec.; El Encino, Vda. Las Minas, Fca. Los Nogales; 2280 m a.s.1.; 6 ${ }^{\circ} 6^{\prime 2} 8^{\prime \prime}$ N, 733'7.6" W; Dec. 2014; A. Lopera and R. Sarmiento; ECC • 1 spec.; Virolin, SFF Guanenta Alto rio Fonce; 2450 m a.s.1.; 2 Feb. 1998; J. Martínez leg.; IAvH. - Tolima • 1 §̊; Ambalema; Nevinson leg.; BMNH 1918-14 • 7 specs; Armero, Guayabal, Loma Santo Tomás; 300 m a.s.1.; 455'70" N, 4952' W; Nov. 1995; F. Escobar leg.; IAvH • 6 specs; Armero, Guayabal Mendez Had. Bremen; 300 m a.s.1.; 55'31" N, 74²4 $81^{\prime \prime}$ W; excr. humano; Nov. 1995; F. Escobar leg.; IAvH • 1 spec.; Mariquita, Bosque Municipal; 650 m a.s.1.; 28 Sep. 2003; V. Fuentes leg.; ECC • 1 spec.; R.N. La Victoria; 700 m a.s.1.; 4¹4'45.9" N, 74³5'37.9" W; Apr. 2015; A. Lopera leg.; ECC. - Valle del Cauca • 1 spec.; Buga, La Magdalena; 1600 m a.s.1.; Mar. 1991 spec.; C. Medina leg.; ECC • 1 spec.; Cali; 1000 m a.s.l.; Oct. 1990; Jorge Aldana leg.; ECC • 1 spec.; Calima; 900 m a.s.l.; Nov. 1993; R. Bravo leg.; ECC 1 \%; 19 mi. S of Cartago; 960 m a.s.l.; 18 Mar. 55; E.I. Schlinger and E.S. Ross leg.; CEMT 11 spec.; Dagua, Chicoral; 1900 m a.s.l.; Jun. 1990; C. Medina

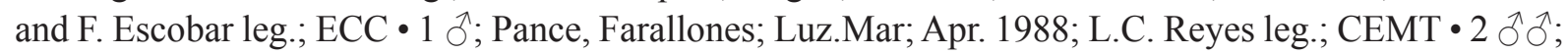
Pance, Farallones; Luz; 25 Dec.-2 Jan. 1991; L.C. Pardo leg.; CEMT • 1 §, 1 क; Buenv ${ }^{\mathrm{a}}$ [possibly

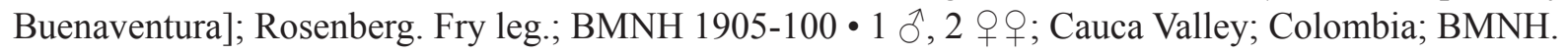

\section{Redescription}

Male

MEASUREMENTS. Length: $17.9 \mathrm{~mm}$. Setae on body surface sparse or absent.

HEAD. Anterior third surface rugose, not extending posteriorly to base of cephalic carina. Clypeus with central weak emargination separating two short rounded clypeal teeth (Fig. 5A, D). Cephalic carina higher than wide, antero-posteriorly flattened, looking like triangular-shaped plate in frontal view. Anterior surface of cephalic carina smooth, with microscopic punctures. Median tubercle twice the high of lateral tubercles. Lateral tubercles acuminate apically (Fig. 5D, G). Ventral clypeal process greatly emarginate (Fig. 2C)

Pronotum. Gibbous, imperceptibly emarginate at antero-medial portion. Wider than long, as wide as elytra; pronotal disc shiny, with fine indistinct punctures. Medial sulcus weakly impressed. Ocellate punctures along posterior and anterior margins (Fig. 5A, D, G), absent in lateral margins. Hypomeron with broad ocellate setigerous punctures separated by less than half the width of a puncture. Medial disc smooth, without punctures. External margin bearing multiple rows of disorganized long setae when seen in dorsal view (see Fig. 2E).

ABDomen. Mesosternum covered by large ocellate setigerous punctures, setae as long as in mesosternum. Metepisternum smooth with some weakly marked punctures. Metasternum setigerous punctures restricted mainly to lateral areas. Antero-median portion with some feebly marked punctures next to apical margins of coxa. Lateral surface of metasternum with ocellate punctures separated by two or three times width of a puncture, some punctures with long setae. Metepisternum suture clearly visible. Ocellate punctures along anterior margin of each sternite, denser in lateral areas, without reaching the centre. Pygidium surface covered by fine punctures, basal margin with wide punctures that merge at the centre. 


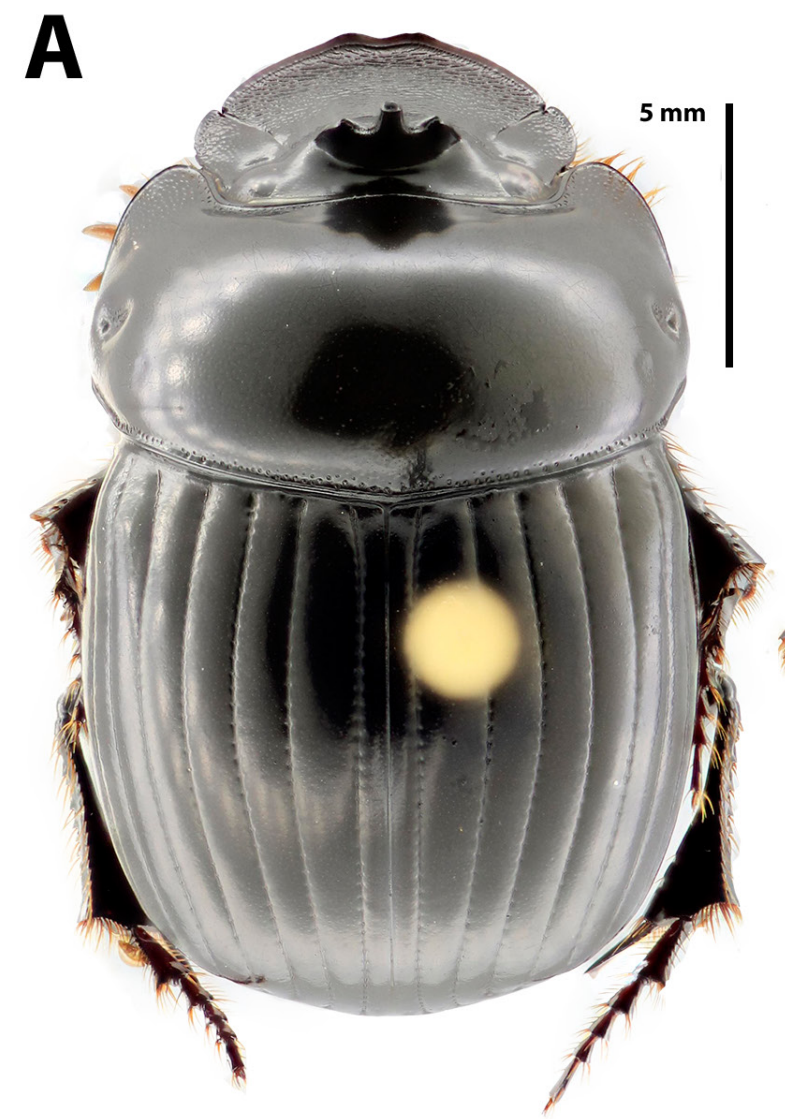

\section{B}
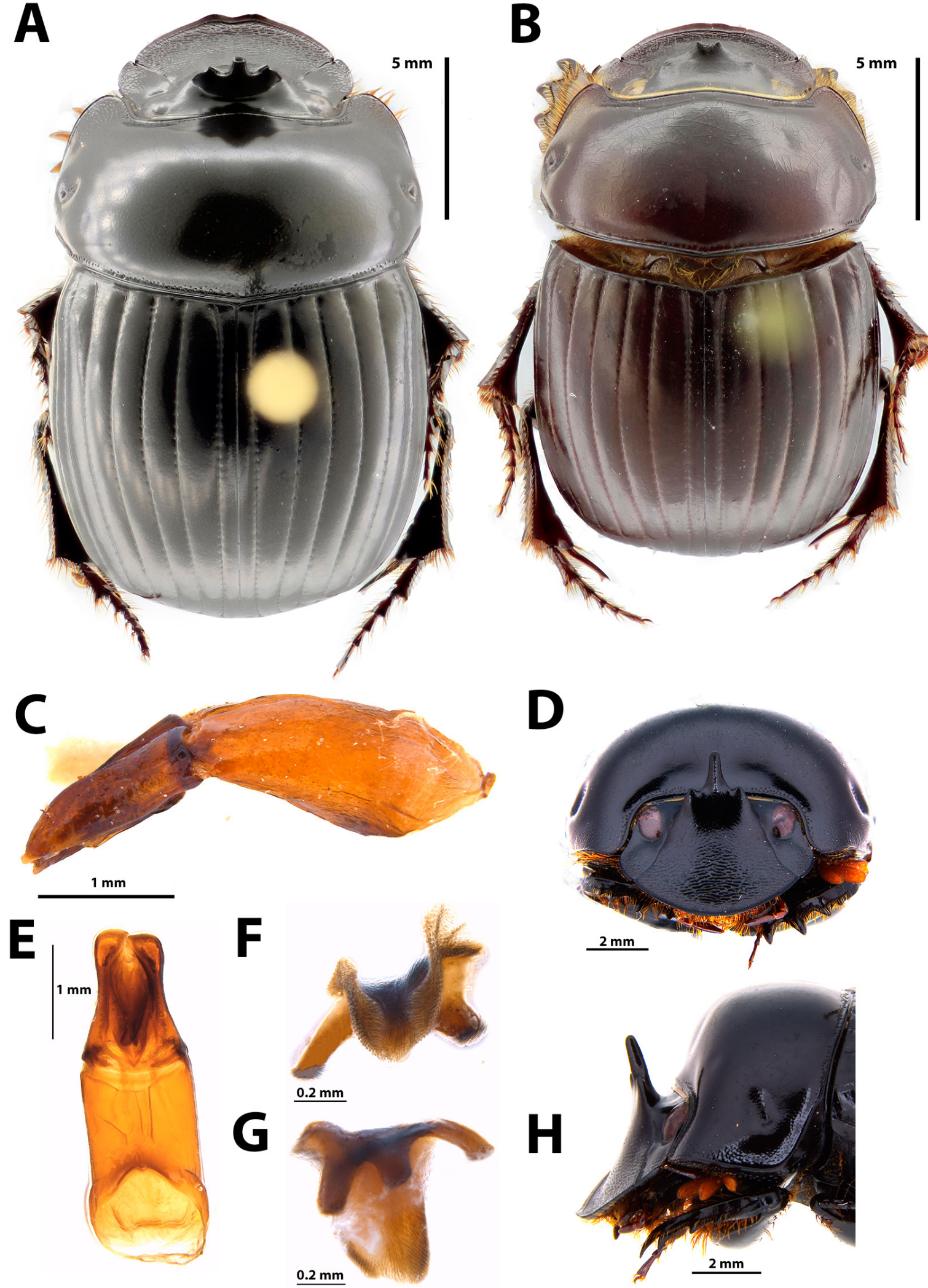

Fig. 5. Dichotomius belus (Harold, 1880). A-B. Dorsal habitus. A. §. B. †. C. Lateral view of the aedeagus. D. Anterior view of the shape of the cephalic carina. E. Ventral view of the aedeagus. F-G. Lamella copulatrix. H. Lateral view, showing the pronotum and the cephalic carina flattened antero-posteriorly and curved anteriorly. 
ELYTRA. Interstriae smooth (see Fig. 2I) and shiny with fine randomly separated punctures. Striae well delimited, punctures separated by once or twice diameter of a puncture on elytral disc.

LEGs. Metacoxa glabrous. Fore calcar bifurcate.

Parameres and lamella copulatrix. As in Fig. 5C, E-F.

\title{
Morphological variation
}

Females (Fig. 5B)

As males except for the following characters:

HEAD. Rounded, clypeal margin not emarginate or faintly emarginate. Surface almost completely rugose, denser on anterior portion. Fronto-clypeal carina quadridentate. Interocular space shiny and smooth.

Pronotum. Smooth, shiny. Hypomeron setae longer and denser than in males.

\section{Remarks}

Dichotomius belus is endemic to Colombia and is distributed throughout the dry zones of the Andes mountains and lowlands associated with the interior of the Tropical Dry Forests. Based on the original description, specimens used to describe the species were collected in Medellín, Ambalema and Ocaña.

\section{Dichotomius (Luederwaldtinia) centralis (Harold, 1869)}

\author{
Fig. 6, Map 4
}

Pinotus centralis Harold, 1869: 502 (original description)

Pinotus centralis - Blackwelder 1944: 69.

Dichotomius centralis - Halffter \& Matthews 1966: 1. — Kohlmann \& Solís 1997: 345.

\section{Diagnosis}

Dichotomius centralis is separated from the other species in the group by the following combination of characters: pronotum covered by dense subrugose punctures. Elytral striae strongly marked, wide and crenulate, easily observable by unaided eye, punctures undefined and crenulate, separated by the width of a puncture.

\section{Material examined}

Lectotype (here designated)

NICARAGUA • O'; "Nicaragua" [white, hw]/"Sallé Coll." [white, p]/ "Pinotus centralis type Harold apud. Sallé" [white, hw]/ "722" [green, p]/ "Type" [white, rounded with red margin, p]/ "B.C.A. p52 sp3" [white, p]/ "LECTOTYPE" [red with black margins, p]/ "Pinotus centralis LECTOT. Ha. Det, F. Vaz-de-Mello, 2011" [white with black margins, phw]; BMNH.

\section{Paralectotype}

NICARAGUA • 1 क; "Type" [white, rounded with red margin, p]/ "Nicaragua” [white, p]/“Sallé Coll." [white, p]/ "Pinotus centralis type. Harold. Apud Sallé" [white with black margins, hw]/"B.C.A. p.52 sp.3" [white, p]/ "PARALECTOTYPE" [yellow with black margins, p]/ "NHMUK 010847042" [white, p]; BMNH.

\section{Additional material}

BELIZE - 2 + $O$; R. Carstoon [Sarstoon River]; B. Honduras [British Honduras]; Blancaneau B.C.A;

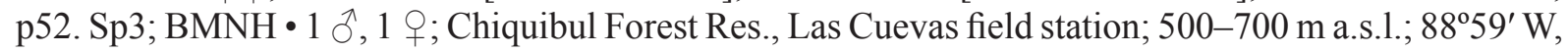
$16^{\circ} 44^{\prime}$ N; May-Jun. 1997; D. Inward leg.; BMNH 2005-78. 
COSTA RICA • 2 ภิ Cartago 3 और 3 qo+; Paraiso; $300 \mathrm{ft}$ a.s.1.; Champion; B.C.A; p52. Sp3; BMNH. - Guanacaste • 1 §ิ, 1 O; Cañas, 3 km N of Hacienda La Pacífica; 90 m a.s.1.; 5-6 Jun. 1979; H. and A. Howden leg.;

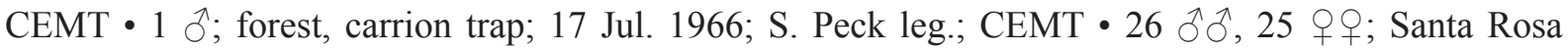
NP, S Santa Rosa Estac. Biol.; 277 m a.s.1.; 1052'10.4" N, 85³5'56.6" W; SEC. FORRESR; 15-19 Nov. 2003; L.G. Uhler leg.; BMNH • 2 qo ; Santa Rosa NP, Cuajiniquil-Sta. Helena; 1054'28.8" N,

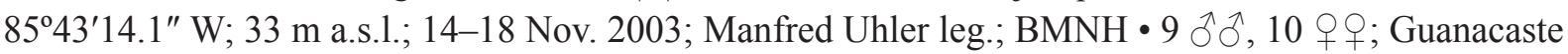

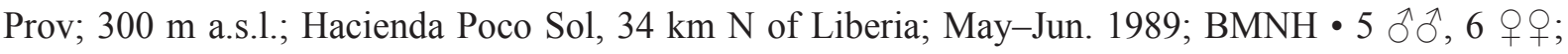
Guanacaste Prov. 11 km SW of Santa Rosa, nr Nancite Beach; May-Jun. 1989; BMNH・ 4 ふえ Guanacaste Prov.; $10^{\circ} 50^{\prime}$ N, 85³7' W; 300 m a.s.l.; bosque humido [Humedo]; May-Jun. 1989; BMNH.

GUATEMALA• 1 ภ, 2 우; Suchitepequez, Cuyatenango, Chacalte Sia; V Jun. 1993; E. Espana; CEMT.

\section{Redescription}

\section{Male}

MeAsurements. Length: $18.5 \mathrm{~mm}$.

HEAD. Most of clypeal and genal surface rugose. Cephalic carina wider than high, anterior surface rugose. Median tubercle twice as high as lateral tubercles, conical in shape and not emarginated at apex; surface smooth, posterior portion rugose. Ventral clypeal process truncate and distally expanded (see Fig. 2B).

Pronotum. Twice as wide as long. Anterior portion displaying accentuated declivity, dense sub-rugose punctures reaching antero-lateral fossae, separated by the width of a puncture (Fig. 6D). Pronotal disc covered by simple punctures, each of these punctures with fine microsculpture. Longitudinal sulcus weakly impressed. Anterior and posterior margins bearing row of disorganized ocellate punctures. Hypomeron middle edge smooth, without punctures. External margin with single row of disorganized long setae, all approximately same length.

ABDOMEN. Mesosternum and metepisternum covered by large ocellate setigerous punctures. Metasternum setigerous punctures restricted mainly to lateral and anterior areas. Anterior lobe pilosity does not connect with lateral pilosity through margins of mesocoxa (see Fig. 2H). Lateral ocellate punctures separated by three times width of a puncture, setae long reaching metepisternal suture, suture visible. Longitudinal sulcus weakly marked. Ocellate punctures along anterior margin of each sternite, denser in lateral areas. Pygidium surface covered by simple punctures, basal margin bearing dense ocellate punctures.

ELYTRA. Surface of interstriae with shagreened microsculpture (see Fig. 2J). Striae strongly marked, wide and crenulate, easily detectable without stereoscope, separated by one time width of puncture (Fig. $6 \mathrm{H}$ ).

LEGS. Metacoxa posterior edge bearing single row of organized ocellate setigerous punctures, separated by width of a puncture.

Parameres and lamella copulatrix. As in Fig. 6C, E-F.

\section{Morphological variation}

Females (Fig. 6B)

As males except for the following characters:

HEAD. Surface completely rugose. Fronto-clypeal carina quadridentate, median tubercles higher than lateral. 

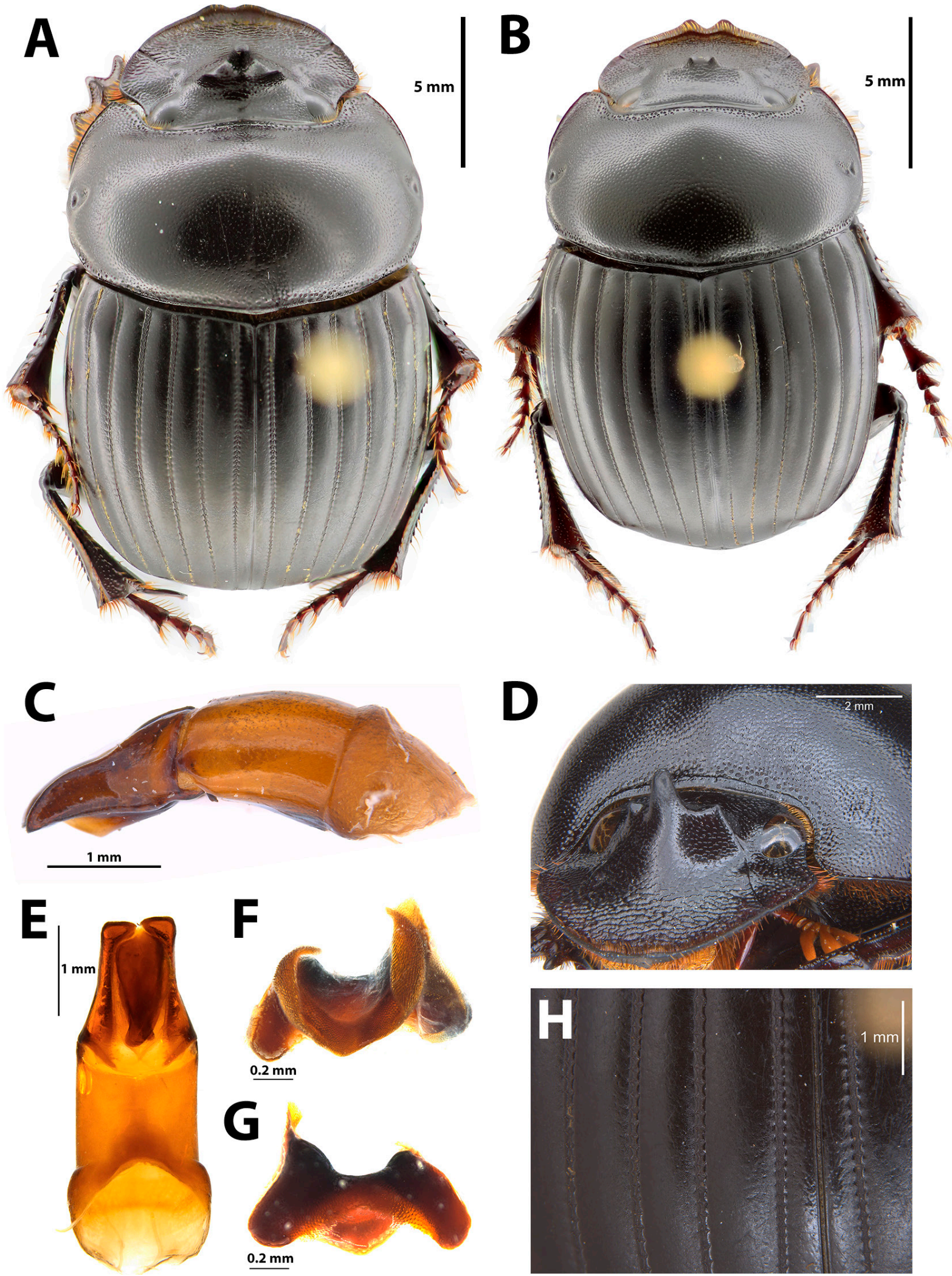

Fig. 6. Dichotomius centralis (Harold, 1869). A-B. Dorsal habitus. A. §. B. ๆ. C. Lateral view of the aedeagus. D. Anterior view, head surface rugose, pronotal anterior surface showing subrugose punctation. E. Ventral view of the aedeagus. F-G. Lamella copulatrix. H. Elytral striae with crenulate punctures. 
Pronotum. Weak medial knob, inconspicuous, observable in lateral view. Anterior and lateral surface covered by subrugose punctures fading towards medial disc. Hypomeron setae longer and denser than in males.

ELYTRA. Striae wider. Striae punctation undefined, crenulate and separated by half, or less width of a puncture.

\section{Remarks}

This species occurs in Belize, Costa Rica and Guatemala. The original description specified that the type series was collected in Granada, Nicaragua. Other published works report it for El Salvador (Kohlmann \& Solís 1997; López-Guerrero 2005). López-Guerrero (2005) argues that it is marginally likely to find this species in the south of Mexico, precisely in the state of Chiapas due to the proximity to Guatemala.

Dichotomius (Luederwaldtinia) deyrollei (Harold, 1869)

Fig. 7, Map 5

Pinotus deyrollei Harold, 1869: 139 (original description).

Pinotus deyrollei - Luederwaldt 1929: 99. - Blackwelder 1944: 69.

Dichotomius deyrollei - Roze 1955: 44. — Medina et al. 2001: 138. — Sarmiento \& Amat 2014: 93-95.

\section{Diagnosis}

Dichotomius deyrollei is separated from the other species in the group by the following combination of characters: clypeus with central emargination displaying two rounded, dorsally angled clypeal teeth. Cephalic carina, higher than wide, antero-posteriorly flattened. Median tubercle approximately twice as high as lateral tubercles and gently inclined anteriorly, apically expanded and emarginate. Anterior portion of pronotum displaying sharp declivity, antero-medial area deeper and convex than lateral and where the longer, median tubercle can fit if head capsules is rotated dorsally.

\section{Material examined}

Lectotype (here designated)

COUNTRY UNKNOWN • đ̃; "Brasilia. P. Deyrollei Harold" [white with red margins, hw]/ "ExMusaeo E. Harold" [white with black margins, p]/ "Museum Paris ex Coll. R. Oberthur" [green, p]/ “LECTOTYPE ${ }^{\lambda}$ Pinotus deyrollei Harold des. F.Z. Vaz-de-Mello, 2014" [red with black margin, phw]; MNHN.

\section{Paralectotype}

COUNTRY UNKNOWN • 1 क; "Ex-Musaeo E. Harold” [white with black margins, p]/ "Museum Paris ex Coll. R. Oberthur" [green, p]/“LECTOTYPE $q$ Pinotus deyrollei Harold des. F.Z. Vaz-de-Mello, 2014" [red with black margin, phw]; MNHN.

\section{Additional material}

COLOMBIA - Casanare 1 spec.; Yopal, Guarataro; 600 m a.s.1.; Bosque seco Tropical; Mar. 1996; A. Lopera leg.; ECC. - Meta • 1 spec.; PNN Tinigua, Varzea; Mar. 1993; Ivan Jiménez leg.; ECC. - Norte de Santander $\bullet 1$ đ̊; $3 \mathrm{Km} \mathrm{N}$ of Chinacota; $1000 \mathrm{~m}$ a.s.1.; dung carrion traps, T10; 10 May 1974; S. Peck leg.; CEMT • 1 spec.; Villa Marina; 1200 m a.s.l.; Feb. 2007; S. Ardila leg.; ECC. - Santander • 10 specs; Charalá Vda. El Salitre, Fca. Buenos Aires; 1730 m a.s.1.; 6³2'39" N, 73³9'6.9” W; 11 Apr. 2016; C.Giraldo and A. León, J leg.; IAvH. 
TRINIDAD • 1 ○े; B.W.I Arima Valley; 30 Apr. 1950; CEMT・ 1 क; 2 May 1953; CEMT.

VENEZUELA - Mérida • 2 q $q$; Arzobispo Chacón, Mucutuy; 1380 m a.s.1.; 8¹4'18" N, 71¹7'12" W; 13 Mar. 2015; Racconcia; CEMT. - Miranda • 1 गे; Guarenas, Curupao; 19 Jul. 1959; Bordon leg.; MLP • 1 đ̊; Táchira, 4 Km SE of San Cristobal; 700 m a.s.l.; dung traps; 19 May 1974; S. Peck leg.;

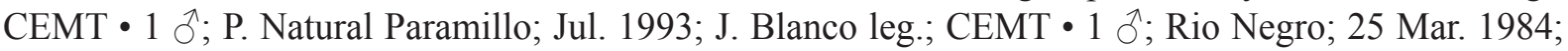
B. Joffre leg.; CEMT 1 1 ; 2.5 km from San Cristobal to Chorro del Indio; 1100 m a.s.l.; 7 p.m.; 1

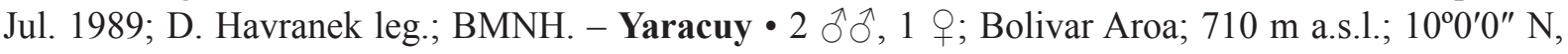
$68^{\circ} 0^{\prime} 0^{\prime \prime} \mathrm{W}$; heces humanas; 20 Jul. 2009; M. Asmüssen, P. Colmenares and H. Martínez leg.; CEMT.

\section{Redescription}

\section{Male}

Measurements. Length: $28.7 \mathrm{~mm}$.

HEAD. Surface of anterior third rugose not reaching base of cephalic carina. Clypeus central emargination separating two rounded and dorsally angled clypeal teeth (Fig. 7A, D). Cephalic carina higher than wide, antero-posteriorly flattened; anterior surface with well-marked punctures. Median tubercle approximately twice as high as lateral and gently inclined anteriorly, expanded and emarginate apically. Lateral tubercles, in frontal view, with two acute apices (Fig. 7D). Ventral clypeal process truncate (see Fig. 2B).

Pronotum. Wider than long. Pronotal disc shiny and smooth, covered by fine punctures. Antero-medial edge with strong convex declivity, which in the centre could accommodate the large frontal carina (Fig. 7A). Row of interrupted ocellate punctures arranged along anterior and posterior margins, fewer and scattered on lateral margins. Hypomeron anterior edge, presenting rounded ocellate punctures with long setae, punctures separated by one time the width of a puncture. Hypomeron medial disc smooth (see Fig. 2E), without punctures. External margin bearing single row of organized long setae, all approximately of same length (see Fig. 2F).

ABDOMEN. Mesosternum and metepisternum fully covered by dense ocellate-setigerous punctures. Metasternum setigerous punctures restricted mainly to lateral and anterior areas (Fig. 7H). Pilosity of anterior lobe of metasternum connecting with lateral pilosity through margin of mesocoxa (Fig. $7 \mathrm{H}$ ). Lateral surface of metasternum covered by ocellate setigerous punctures separated by twice width of a puncture, setae long and dense, covering lateral surface of metasternum and metepisternal suture. Ocellate setigerous punctures along antero-lateral margins, denser at lateral areas. Pygidium surface covered by fine punctures, basal margin with scattered ocellate punctures.

ElYTRA. Interstriae microsculpture shagreened (see Fig. 2J). Striae deeply impressed, crenulate, punctures separated by diameter of a puncture on elytral disc.

Legs. Metacoxa posterior edge bearing single row of disorganized setigerous punctures, separated by half or less the diameter of a puncture.

Parameres and lamella copulatrix. As Fig. 7C, E-F.

\section{Morphological variation}

Females (Fig. 7B)

As males except for the following characters:

HEAD. Surface transversely rugose, denser on anterior portion. Cephalic carina with pair of high medial tubercles. 


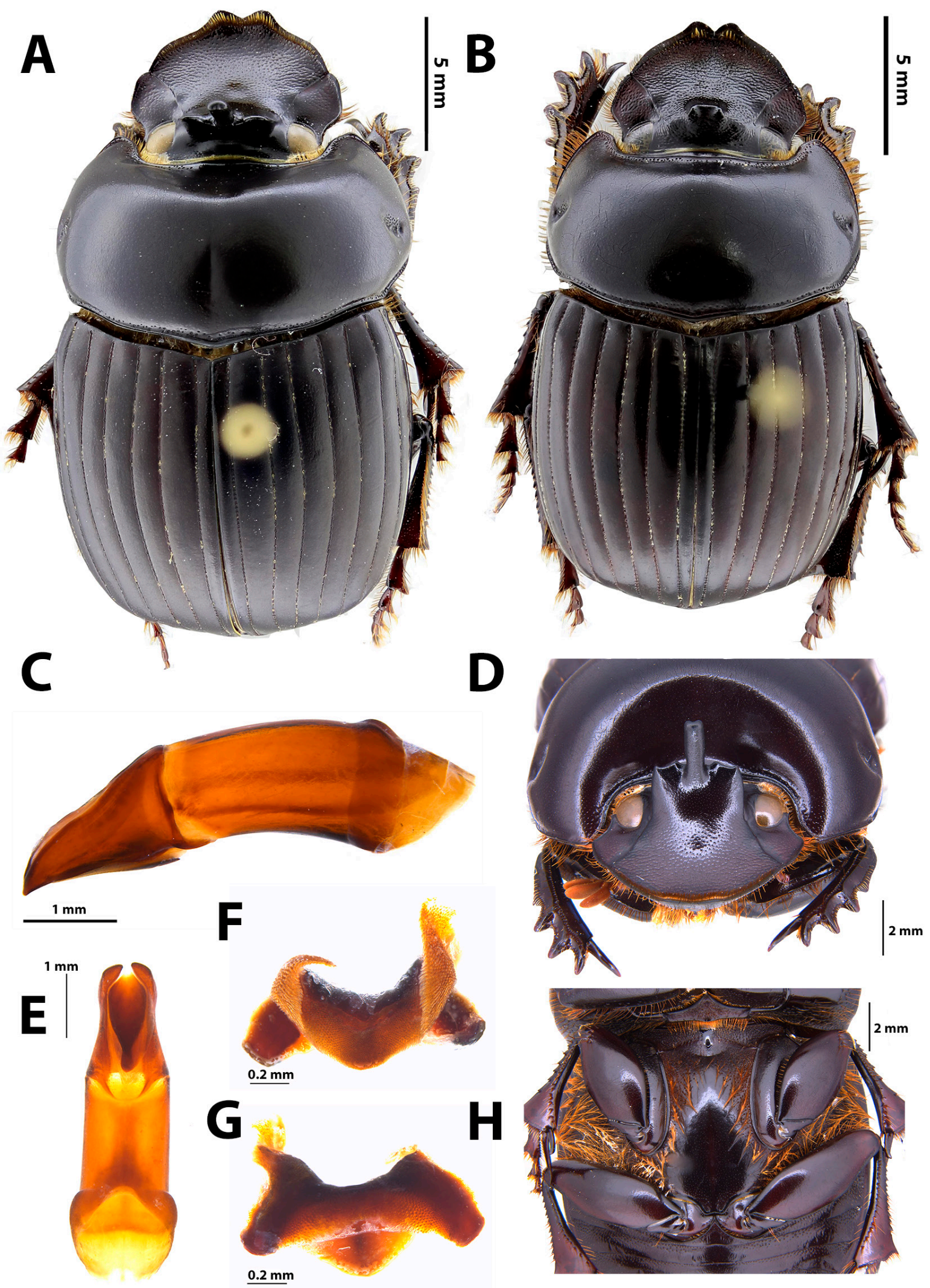

Fig. 7. Dichotomius deyrollei (Harold, 1869). A-B. Dorsal habitus. A. O. B. ㅇ. C. Lateral view of the aedeagus. D. Anterior view of the head cephalic carina. E. Ventral view of the aedeagus. F-G. Lamella copulatrix. H. Metasternum dense pilosity. 
Pronotum. With weak medial knob, observable in lateral view. Uninterrupted ocellate punctures throughout lateral margins. Hypomeron punctures ocellate and setigerous, equally spaced; setae longer and denser than in males. Metasternum almost completely covered by ocellate setigerous punctures, metasternal lobe smooth with fine and deeply impressed punctures.

ElYTRA. Smooth, with scattered fine punctures.

ABDOMEN. Sternites dense ocellate punctures covering anterior margin.

\section{Remarks}

This species occurs in Colombia and Venezuela. The distribution of the species closely follows that of the Andes Mountains. The original description notes that the type specimens were from "Brésil", without any other specification of the locality. However, as far as we know this Andean species does not occur in Brazil.

Dichotomius (Luederwaldtinia) enioi sp. nov. urn:1sid:zoobank.org:act:E526BCF4-2B99-42E3-B18B-DC9FE1ED0D7B

Fig. 8, Map 16

\section{Diagnosis}

Dichotomius enioi sp. nov. is separated from other species in the group by the following combination of characters: males interocular space microsculpture shagreened, with flat, well-defined punctures resembling rugosity. Median tubercle conical, twice as high as lateral, with fine apical emargination; lateral tubercles with acute apex. Row of dense uninterrupted ocellate punctures arrange along anterior and posterior margin of Pronotum. Anterior disc declivity with weak anteromedian lobe subemargination. Interstriae microsculpture shagreened.

\section{Etymology}

Dichotomius enioi sp. nov. is an eponym after Enio Cano, a Guatemalan scientist who contributes to the study of Scarabaeoidea.

\section{Material examined}

\section{Holotype}

GUATEMALA • Ō; "Petén, Flores, El Remate, Biot. Cerro Cahuí; 28-29 VII 1995; Col. E.B. Cano"/"Bosque guamil alto, Colecta nocturna, con heces humanas"/"Dichotomius agenor (Harold), Det. E. Cano, 1996." [white, p]; CEMT.

\section{Paratypes}

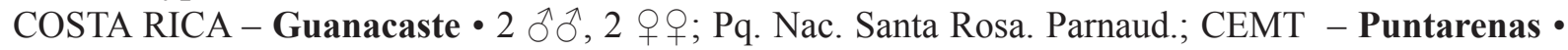
1 ภ, 1 क ; Est. Queb. Bonita, 50 m. Res. Biol. Carara L-N-194500; 469850; Jun. 1993; J.C. Saborío leg.; CEMT.

GUATEMALA - Petén • 1 ภ̂, 1 q; Flores, El Remate, Biot. Cerro Cahuí; 28-29 Jul. 1995; E.B. Cano leg.; CEMT • 1 क; Parque Nac. Tikal, área \#1-B; 5-6 Sep. 1995; G. Orellana leg.; CEMT.

MEXICO - Campeche • 3 ふぇ, 2 ๆ $९$; Xpujil; 26 Jul. 1995; J.L. Moreno and T. Mestre leg.; CEMT.

\section{Description}

Male

MEASUREMENTS. Length: $21.47 \mathrm{~mm}$. Dorsal and ventral surface black. 


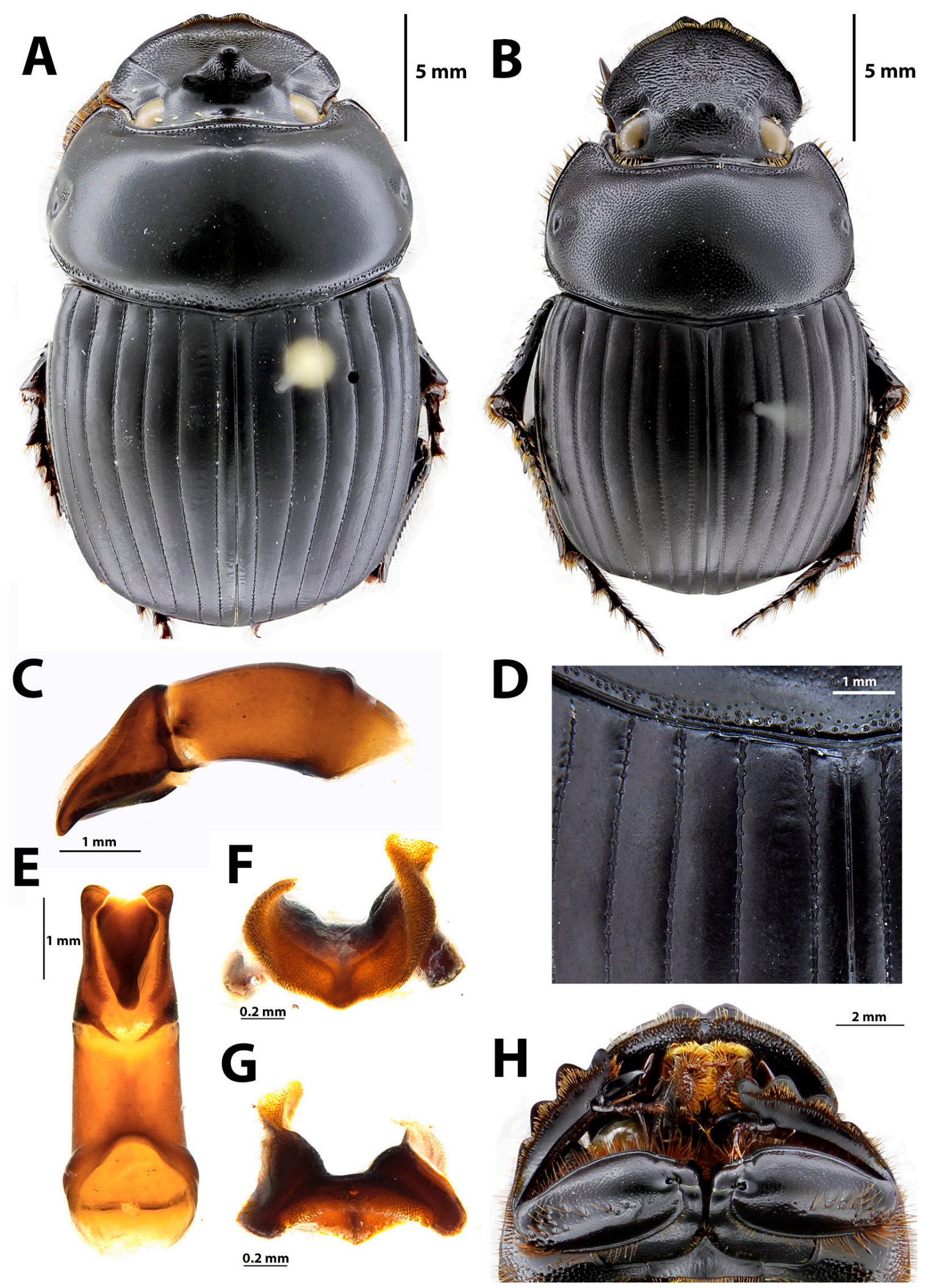

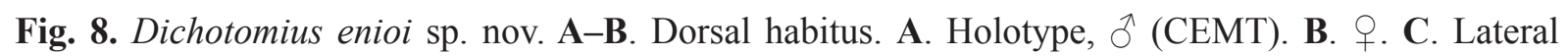
view of the aedeagus. D. Ocellate punctation of the posterior margin of the pronotum; elytral interstriae shagreened. E. Ventral view of the aedeagus. F-G. Lamella copulatrix. H. Profemur covered with wellimpressed punctures, setigerous setae near the medial edge. 
HEAD. Anterior surface rugose. Interocular surface microsculpture shagreened, with flat, well-defined punctures. Clypeus with central emargination separating two short, rounded clypeal teeth. Cephalic carina wider than high. Median tubercle twice as high as lateral tubercles, conical in shape and with fine apical emargination, lateral tubercles apical acute. Ventral clypeal process truncate (see Fig. 2B).

Pronotum. Wider than long. Pronotal median disc shiny covered with simple well-impressed punctures, scattered dense uninterrupted ocellate punctures along anterior and posterior margins, absent in lateral margins (Fig. 8A, C). Anterior disc pronounced declivity with impressed longitudinal sulcus producing weak anteromedian lobe subemargination. Hypomeral disc smooth, external margin bearing multiple rows of disorganized long setae, approximately same length, (see Fig. 2E).

AвDOMEn. Prosternum surface microsculpture shagreened. Mesosternum and metepisternum surface covered by large ocellate setigerous punctures. Metasternum setigerous punctures restricted to anterior and lateral edges of mestasternal lobe. Setigerous punctures connecting antero-median edge with lateral through margin of mesocoxa (see Fig. 2G); lateral edge of metasternum with ocellate setigerous punctures separated by diameter of a puncture, setae reaching metepisternum suture. Sternite with ocellate punctures along anterior margins of each sternite, denser in lateral areas. Pygidium microsculpture shagreened with scattered well-impressed simple punctures; basal margin bearing row of ocellate punctures.

ElYTRA. Interstriae microsculpture shagreened (Fig. 8C). Striae with ocellate punctures separated by diameter of a puncture on elytral disc.

Legs. Fore calcar spiniform, profemur surface covered by clearly impressed punctures (Fig. 8D); metacoxa posterior margin bearing row of organized ocellate setigerous punctures.

Parameres and lamella copulatrix. As in Fig. 8E-G.

\title{
Morphological variation
}

Females (Fig. 8B)

As males except for the following characters:

HEAD. Surface completely transversely rugose, denser on anterior portion. Cephalic carina quadridentate and greatly elevate, median tubercles higher than lateral.

Pronotum. Without medial declivity and sub-emargination, punctures dense and deeply impressed, separated between them by once the diameter of same.

AвDOMEn. Sternites lateral punctuation denser than in males. Pygidium surface punctation wider and denser than in males.

\section{Remarks}

It is possible that Kohlmann \& Solis (1997) and López-Guerrero (2005) reported this species for Central America as Dichotomius agenor.

\section{Dichotomius (Luederwaldtinia) fornicatus (Luederwaldt, 1931)}

\author{
Fig. 9, Map 6
}

Pinotus opacipennis var. fornicatus Luederwaldt, 1931: 302 (original description).

Dichotomius bosqi Pereira, 1941: 263 (original description). Syn. nov.

Dichotomius opacipennis var. fornicatus - Blackwelder 1944: 207.

Dichotomius bosqi Martínez 1959: 89. 


\section{Diagnosis}

Dichotomius fornicatus is separated from other species in the group by the following combination of characters: small body size, less than $15 \mathrm{~mm}$. Dorsal and ventral surface dark blue to black. Head cephalic carina, distinctly arcuate in dorsal view, middle edge slightly forward of lateral. Pronotum with abrupt anterior declivity when viewed laterally, middle surface deeper, apex of the declivity with two well-developed lobes. Elytra opaque, shagreened microsculpture.

\section{Material examined}

Holotype of $P$. fornicatus

ARGENTINA • + ; "Republ. Argentine CHACO DEL ESTERO, RIO SALADO" [white with black superior and inferior margins, p]/ "DÉCEMBRE" [white, p]/ "MÚSEUM PARIS 1938 COLL. A. BOUCOMONT" [green with black margins, p]/ "Pinotus opacipennis Lueder. Forma a. Luederw. Det. 1931 " [white, hw]; MNHN.

Holotype of D. bosqi

ARGENTINA • J'; "Sgo del ESTERO. Rio Salado. WAGNER col." [white with black margins, p]/ "TIPO" [red with black margins, p]/ "Pinotus bosqi P. Pereira det. 940" [white with black margins, phw]/ "23.030” [white, hw]; MZSP.

\section{Paratype}

ARGENTINA - 1 क; "Sgo del ESTERO. Rio Salado. WAGNER col." [white with black margins, p]/ " " [white, hw]/ "Paratypo" [red, hw]/ "Pinotus bosqi + P. Pereira det. 941" [white with black margins, phw]/“289” [red rounded, hw]; MLP.

\section{Additional material}

ARGENTINA - Cordoba • 1 q; La Para. C/esc; Dec. 1996; Monteresino leg.; CEMT • 1 đ̊; C. a mano; Nov. 1990; Monteresino; CEMT • 4 우; Salta, Salado River; J.V. González and S. Macapilo leg.; 18

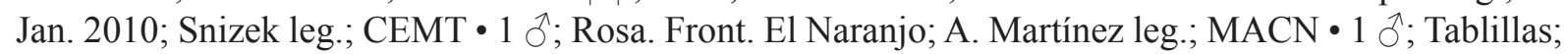
Dec. 1932-Sep. 1933; CEMT. - Santiago del Estero - 2 우; Campo Gallo, S. del. Estero; Mar. 1943;

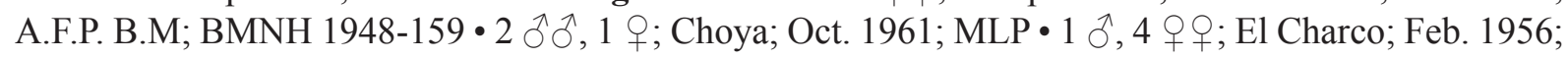

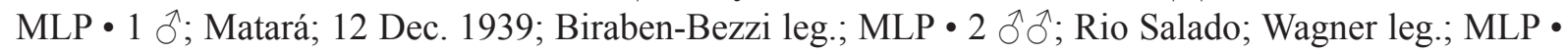
2 ㅇ; Thermas de Rio Hondo; 27-28 Nov. 1979; C. and M. Vardy B.M. leg.; BMNH 1980-67 • 1 ; ; Tucumán; Jan. 1947; CEMT • 1 क; Dec. 1948; CEMT • 1 क; Campo Bello; Mar. 1943; MACN • 1 ô, 1 P; San Pedro Colalao; Feb. 1949; CEMT • 1 đે; "METATIPO"/ "Campo Gallo, S. del Estero III-1943 A.F.P."/ "Pinotus §̊ bosqi P. Pereira det. 948/B.M. 1948-159." /"NHMUK 010847032"; BMNH • 1 q; "METATIPO"/“Campo Gallo, S. del Estero III-1943, A.F.P."/“Pinotus $q$ bosqi P. Pereira det. 948 /B.M. 1948-159"/ "NHMUK 010847033”; BMNH.

BOLIVIA 1 1 ; Cordillera, Tunalito; 8 Nov. 1946; Maldonado leg. and coll. Martinez.; CEMT. Santa Cruz • 1 đ̃, 1 क; Ascención; Nov. 1963; MLP • 1 q; Ñuflo de Cháves; Nov. 1963; MLP •

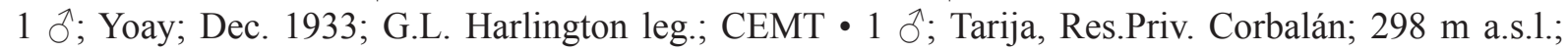
$21^{\circ} 39^{\prime} \mathrm{S} 62^{\circ} 28^{\prime}$ W; chaco seco. trap. caída cebo humano; 12 Dec. 2004; C. Hamel and M. Aliaga leg.;

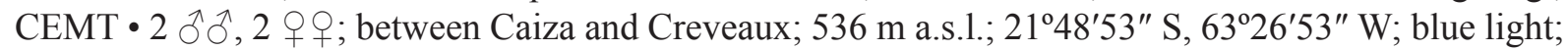
OUMNH-2005-065; 05-I-2005; Mann, Hamel and Herzog leg.; CEMT • 1 के; Yoay and Mandipecua [Yoay y Mandeyapecua]; collector 479; Nov. 1932; Press by WCH rington; CEMT.

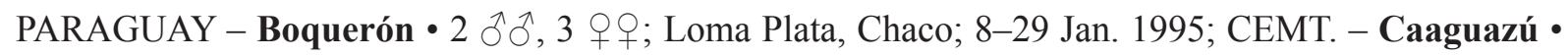

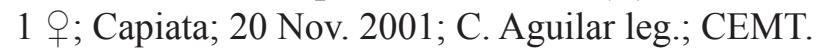

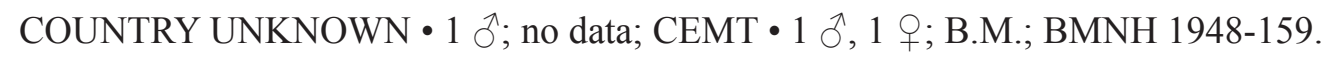




\section{Redescription}

\section{Male}

MeAsurements. Length: $13.35 \mathrm{~mm}$. Dorsal and ventral surfaces dark blue to black. Pronotum and ventral surfaces shiny, elytra opaque.

HEAD. Surface rugosity not extending posteriorly to base of cephalic carina; interocular surface with well-impressed punctures near eyes. Cephalic carina, wider than high, distinctly arcuate in dorsal view (Fig. 9G), middle edge slightly forward of lateral. Median tubercle approximately twice as high as lateral tubercles, conic in shape and slightly curved posteriorly. Ventral clypeal process cylindrical (see Fig. 2D).

Pronotum. Wider than long. Antero-median declivity of pronotal disc with two underdeveloped lobes at sides when viewed laterally (Fig. 9A). Pronotal disc shiny with dense deep punctures, separated by diameter of a puncture; margins rugose, denser at antero-lateral edges. Hypomeron medial disc smooth and shiny, external margin with single row of organized and scattered setae of same length.

ABDomen. Mesosternum covered by large ocellate punctures separated by diameter of a puncture. Metasternum antero-medial edge smooth and shiny. Ocellate punctures restricted mainly to lateral edges, punctures separated by width of a puncture. Small ocellate punctures surrounding margin of mesocoxa (Fig. 9D). Ocellate punctures along the anterior margin of sternites; sixth abdominal sternite lower or depressed than others. Pygidium medial disc finely punctate, delimited by margin that widens towards apical part; basal inner margin rugose.

ElYTRA. Opaque. Interstriae microsculpture shagreened; fine shiny punctures disposed randomly. Striae black, weakly impressed, punctures separated by twice diameter of a puncture on elytral disc.

Legs. Metacoxa posterior edge bearing row of small impressions, not punctures, separated by twice diameter of the impression. Setigerous punctures next to trochanter insertion larger, twice the size of small ones.

Parameres and lamella copulatrix. As in Fig. 9C, E-F.

\section{Morphological variation}

Females (Fig. 9B) are distinguished from the males as follows:

Head. Surface completely rugose, denser towards anterior portion. Cephalic carina trituberculate, median tubercle higher than lateral tubercles, surface punctate. Lateral tubercles narrow.

Pronotum. Weak medial depression, surface punctures greatly impressed separated by length of diameter of a puncture. Medial sulcus conspicuous.

\section{Remarks}

This species was first described by Luederwaldt (1931) based on a female as a variety of D. opacipennis, placing it in the inachus section as part of the lucasi group. The holotype locality was Santiago del Estero, Rio Salado, the same later used by Pereira (1941) to described D. bosqi. The description of the male of this species was by Pereira (1941). Based on the abovementioned taxonomic characters and the possibility of comparing specimens to the holotype, we suggest these species to be synonyms. Within the species group, $D$. fornicatus and $D$. rafanunezi sp. nov. are the only species where the cephalic carinae of females are trituberculate. 

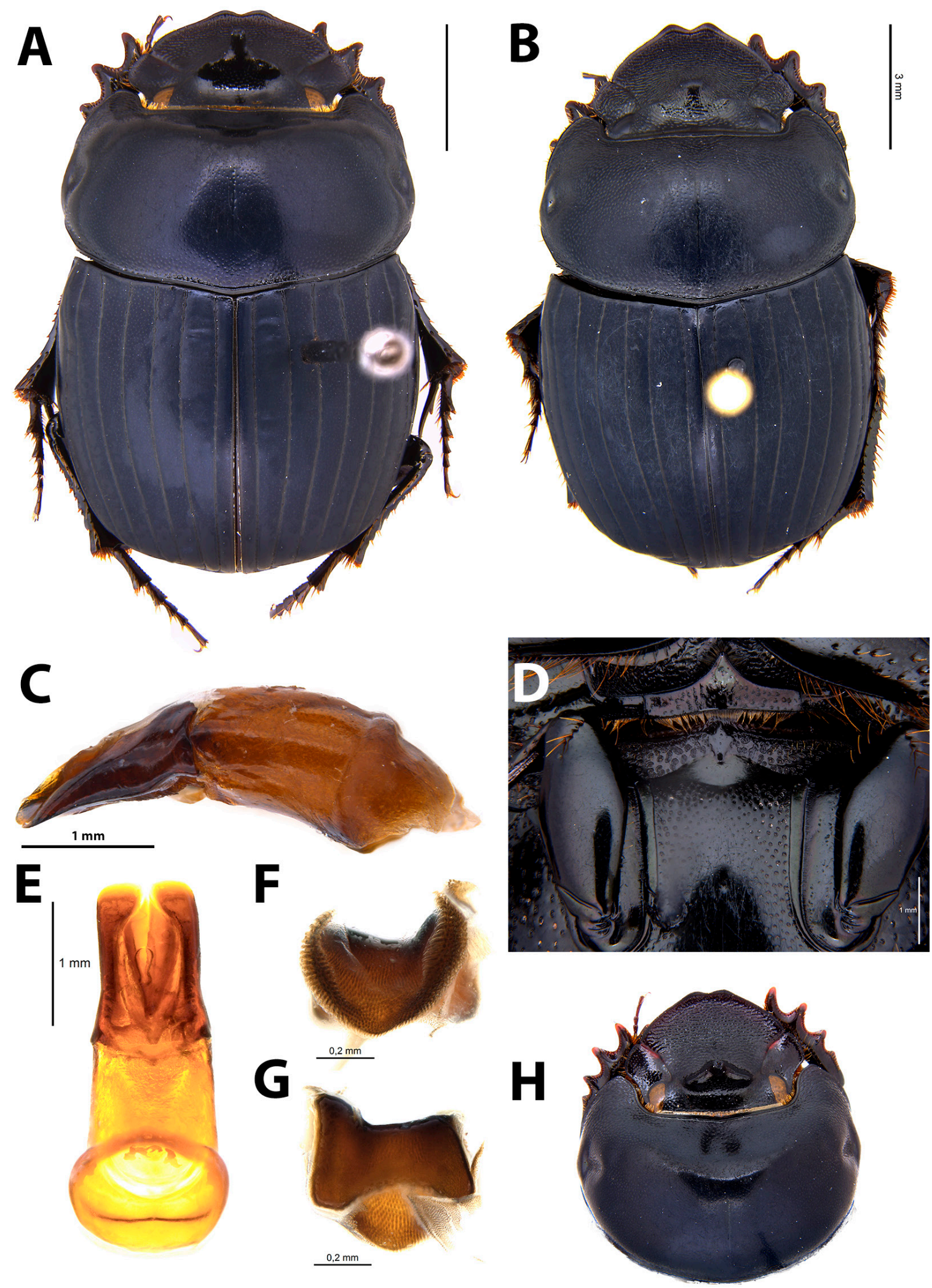

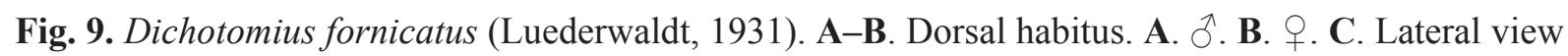
of the aedeagus. D. Ventral view of the metasternum. Antero-medial edge smooth and shiny, surface near the interior margin of the mesocoxae punctate. E. Ventral view of the aedeagus. F-G. Lamella copulatrix. H. View from above of the head, cephalic carina arcuate. 


\section{Dichotomius (Luederwaldtinia) henripittieri sp. nov. urn:1sid:zoobank.org:act:CB39A85C-47A6-4EB8-B538-6D4CEED8BC63}

Fig. 10, Map 11

\section{Diagnosis}

Dichotomius henripittieri sp. nov. differs from other species of the group by the following combination of characters: clypeal teeth short and rounded. Clypeo-genal junction not emarginate. Cephalic carina, wide as high, median tubercle rounded at apex. Dense, ocellate punctures covering interocular surface. Pronotum twice as wide as long. Anterior medial disk with weak declivity, not truncate. Impressed fine punctures restricted to antero-lateral edges. Row of uninterrupted ocellate punctures along pronotal margin. Interstriae microsculpture shagreened.

\section{Etymology}

Name based on the locality where this new species was collected, Henri Pittier National Park, Venezuela.

\section{Material examined}

Holotype

VENEZUELA • 3 ; Aragua, Mario Briceño Iragorry, PN. Henri Pittier, Est. Bio. Periquito; $1145 \mathrm{~m}$ a.s.l.; $10^{\circ} 20^{\prime} 51^{\prime \prime} \mathrm{N}, 67^{\circ} 41^{\prime} 17^{\prime \prime} \mathrm{W}$; human faeces; 18-20 Aug. 2010; R. Acconcia and J. Gámez leg. [white, p]; CEMT.

\section{Paratypes}

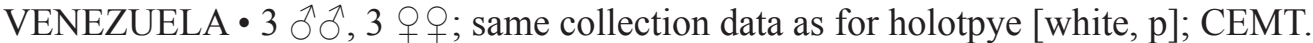

\section{Description}

Male

MEASUREMENTS. Length: $19.36 \mathrm{~mm}$.

HEAD. Wider than long. Anterior edge surface weakly rugose, extending posteriorly not reaching base of cephalic carina. Clypeo-genal surface covered by ocellate punctures spaced by one time diameter of a puncture. Interocular surface with ocellate punctures next to eyes (Fig. 10A, C). Clypeus rounded, weak central emargination separating two rounded clypeal teeth. Ventral clypeal process longitudinally enlarged, cylindrical (see Fig. 2D). Cephalic carina as wide as high, posterior surface shagreened microsculpture with ocellate shallow punctation. Median tubercle three times as high as lateral tubercles and curved posteriorly, apex rounded never bifurcate. Lateral tubercles obtuse at apex, vertically flattened (Fig. 10C).

Pronotum. Twice as wide as long, and as wide as elytra. Anterior medial disc with weak declivity, not truncate. Median disc shiny and smooth, lacking deep punctures and having at most fine punctures. Antero-lateral surface with dense well-impressed simple punctures, scattered ocellate punctures also visible. Row of ocellate punctures along margins, punctures denser at anterior and posterior margins edges. Hypomeron medial disc punctation separated by three times width of a puncture, never smooth or impunctate. External margin bearing single row of organized long setae (see Fig. 2F).

AbDomen. Prosternum and mesosternum with ocellate setigerous punctures. Metepisternum surface shagreened, displaying ocellate setigerous punctures, pilosity sparce. Metasternum setigerous punctures restricted mainly to lateral and anterior areas of mestasternal lobe, puncture diameter variable, medial disc smooth. Margins of mesocoxa surrounded by multiple ocellate punctures, reaching lateral portions of metasternum (Fig. 10D). Lateral surface of metasternum, with ocellate setigerous punctures separated by three times width of a puncture. Ocellate punctures along sternites anterior margins. Pygidium wider than long, basal margin rugose, bearing ocellate punctures in basal half. 

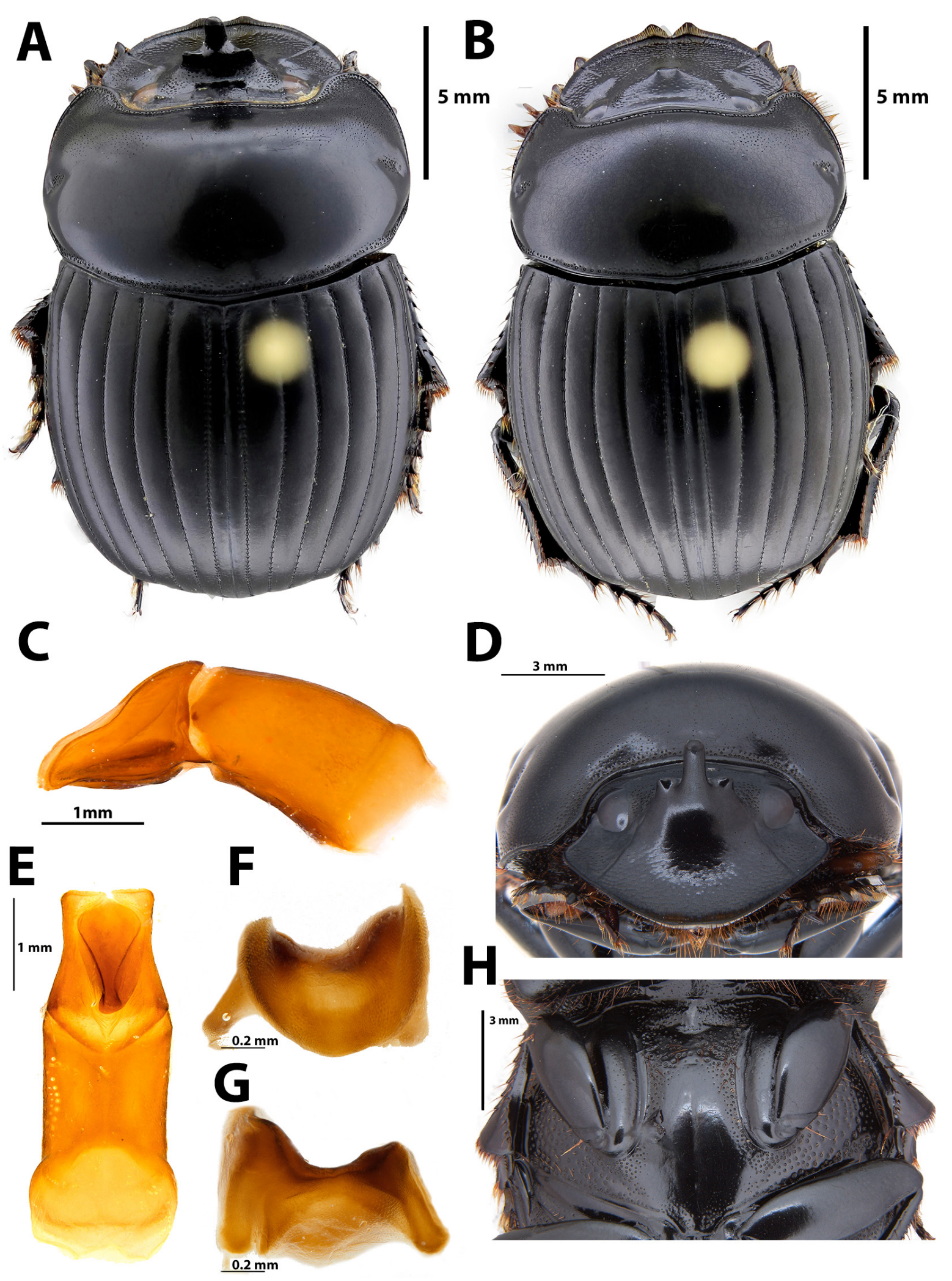

Fig. 10. Dichotomius henripittieri sp. nov. A-B. Dorsal habitus. A. Holotype, ô (CEMT). B. + C. Lateral view of the aedeagus. D. Frontal view of the head, cephalic carina medial tubercle rounded at the apex. E. Dorsal view of the aedeagus. F-G. Lamella copulatrix. H. Ventral view of the metasternum, mesocoxa surrounded by multiple ocellate punctures, medial disc smooth. 
ELYTRA. Interstriae microsculpture shagreened, with smooth fine scattered punctures. Striae wellimpressed with ocellate punctures separated by less the diameter of a puncture on elytral disc (Fig. 10A).

LEGS. Metacoxa posterior edge bearing single row of disorganized ocellate setigerous punctures, separated by twice diameter of a puncture. Profemora displaying aggregation of setigerous punctures on distal $3 / 4$.

Parameres and lamella copulatrix. As in Fig. 10E-G.

\section{Morphological variation}

Females (Fig. 10B)

As males except for the following characters:

Head. Completely transversely rugose, denser on anterior portion. Clypeus with strong central emargination separating two acute clypeal teeth. Cephalic carina bituberculate, tubercles narrow, almost fading (Fig. 10B).

Pronotum. Surface covered by fine punctures, denser on antero-lateral areas. Punctuation on margins ocellate and dense, discernible. Hypomeron setae longer and denser than in males.

\section{Remarks}

This species was collected in the Henri Pittier National Park located on the ridge of the Cordillera de la Costa of Venezuela. The vegetation of the area is characterized by extensive cloud forest.

\section{Dichotomius (Luederwaldtinia) inachoides (Felsche, 1901)}

Fig. 11, Map 8

Pinotus inachoides Felsche, 1901: 144 (original description).

Pinotus inachoides - Luederwaldt 1929: 109. — Blackwelder 1944: 207.

Dichotomius inachoides - Roze 1955: 44.

\section{Diagnosis}

Dichotomius inachoides is separated from other species in the group by the following combination of characters: cephalic carina, wider than high, conical in shape. Median tubercle apex acute, higher than lateral tubercles. Lateral tubercles quadrate. Clypeal margin with tooth or protuberance before clypeogenal junction. Pronotum wider than long, anterior edge of pronotal disc with strong declivity displaying three gibbosities.

\section{Material examined}

\section{Holotype}

VENEZUELA • ; "Merida" (white with black margin, hw]/"Typus" [orange, printed]/ "Coll. C. Felsche Kauf 20, 1918" [green, p]/ "inachoides Felsche Venezuela" [white with purple margins, hw]/"Museum Für Tierkunde Dresden (MTD)" [white, printed]/"Holotype Pinotus inachoides Felsche F.Z. Vaz-deMello 2014" [red with black margins, phw]; SMTD.

\section{Additional material}

COLOMBIA - Cundinamarca • 1 क; 30 Mar. 1990; Diana Cadena and Catalina Dávila leg.; CEMT • 1 spec.; San Francisco F. Lorenzo; 1600 m a.s.1.; 457'23" N, 74º17'20" W; S. Amézquita leg.; ECC • 1 đ ; Santandercito; light; Nov. 1961; CEMT • 2 specs; Tena Laguna Pedro Palo; 2000 m a.s.l.; Jul. 1995; A. Camacho; ECC • 3 specs; Parque Natural Chicaque; 2000 m a.s.l.; 26 Oct. 1996; S. Amézquita leg.; 
ECC • 2 specs; 2700 m a.s.1.; Oct. 1995; A. Lopera leg.; ECC. - Huila • 2 specs; Palestina Jericó; 1980 m a.s.l.; 1 104'45" N, 76²0'29" W; bosque Villa Nora; Aug. 2005; L.E. Franco leg.; ECC • 1 O ; Rivera; light; 15 Nov. 1993; Hector Bonilla leg.; CEMT - 2 specs; San Agustín Corregimiento La Argentina; 2120 m a.s.1.; $1^{\circ} 48^{\prime} 45^{\prime \prime}$ N, 76²0'29" W; Aug. 2005; M. Ospina and H. Londoño leg.; ECC. Norte de Santander • 3 specs; Cucutilla Parque Natural Sisavita, Qda. Poveda Robledal; 2040 m a.s.l.; $7^{\circ} 28.11^{\prime}$ N, 7250' W; Mar. 2002; A.Pulido, E.González and A. Santamaría leg.; ECC.

VENEZUELA - Aragua • 1 q; Cuyagua; 50 m a.s.1.; 6 Jul. 2004; D. García leg.; CEMT. - Barinas • 5 ổ, 5 우우 Bolivar Barinitas, Paguey, Sector El Cacao pie de monte Andino; 1080 m a.s.l.; 3 Sep. 2015; R. Acconcia and J. Gámez leg.; CEMT. - Táchira • 2 o o+; Palmira, La Flautera; 15 Jul. 1985; B. Joffre leg.; CEMT. - Mérida - 1 đ̊; M. Zerpa [Monte Serpa]; 2400 m a.s.l.; copro; Jul. 1995; A. de Ascencao leg.; CEMT • 1 đ; Monte Zerpa, La Hechicera; Nov. 1987; B. Joffre leg.; CEMT • 1 क ; Stn Rosa, La Hechicera; Jun. 1986; B. Joffre leg.; CEMT. - Sucre • 1 ô, 1 क; Jaji; 1891 m a.s.l.; $8^{\circ} 40^{\prime} 24.05^{\prime \prime} \mathrm{N}, 71^{\circ} 24^{\prime} 56.30^{\prime \prime} \mathrm{W}$; cebo heces humanas; 6 Jul. 2009; D. Mora, P. Colmenares, M. Cordova and M. Nuñez leg.; CEMT・1 ठ̊ં; Aug. 1960; CEMT.

\section{Redescription}

Male

MEASUREMENTs. Length: $22.77 \mathrm{~mm}$.

HEAD. Anterior third rugosity not extending base of the central cephalic carina. Clypeus not rounded, with strong central emargination separating two acute clypeal teeth angled upwards. Gena protruding clypeal margin. Tooth or protuberance toward clypeo-genal junction. Cephalic carina wider than high, conical in shape and distinctly apically acute. Median tubercle twice as high as lateral tubercles, apex obtuse. Lateral tubercles quadrate, not apically acute (Fig. 11A, C). Ventral clypeal process truncate and broadened apically (see Fig. 2B).

Pronotum. Wider than long, approximately twice as wide as long and wider than elytra. Anterior edge of pronotal disc with strong declivity displaying three gibbosities (Fig. 11A). Pronotal medial disc shiny with fine punctures, anterolateral edges close to fossae with fine dense punctures. Hypomeron medial disc smooth and shiny, anterior edge with ocellate setigerous punctures aggregated on inner anterior portion next to procoxa; punctures separated by half width of a puncture. External margin bearing rows of disorganized setigerous punctures, setae all approximately of the same length.

AвDOMEN. Prosternum surface shagreened exhibiting longitudinal rugosity and fine setigerous punctures. Mesosternum surface heavily shagreened, with large ocellate setigerous punctures separated by twice the diameter of a puncture. Metepisternum surface shagreened and covered by ocellate-setigerous punctures separated by twice diameter of puncture. Metasternum anterior portion next to basal margin of mesosternum and margins of mesocoxa covered by shagreened microsculpture and dense long setae. Dense pilosity surrounding margins of mesocoxa joining medial edges of metasternum with lateral (Fig. 11D). Longitudinal sulcus distinctly sculpted, ending as shallow mid-fossa. Sternites wide, opaque, with shagreened microsculpture. Small sparse ocellate punctures restricted to anterolateral margins of each sternite, never on middle portions. Pygidium completely delimited by margin, apical part with inner median tooth; surface smooth, large punctures restricted to basal margin. Medial and apical surfaces finely punctate. Punctures simple and well-imprinted.

ELYTRA. Opaque and black, wider than long. Interstriae microsculpture shagreened. Fine shiny punctures arranged randomly and visible only on $7^{\text {th }}$ and $8^{\text {th }}$ interstriae when teneral, otherwise not visible. Striae thin, punctures as wide as line that connects punctures. Punctures separated by at least twice diameter of same on elytral disc (Fig. 11A). 

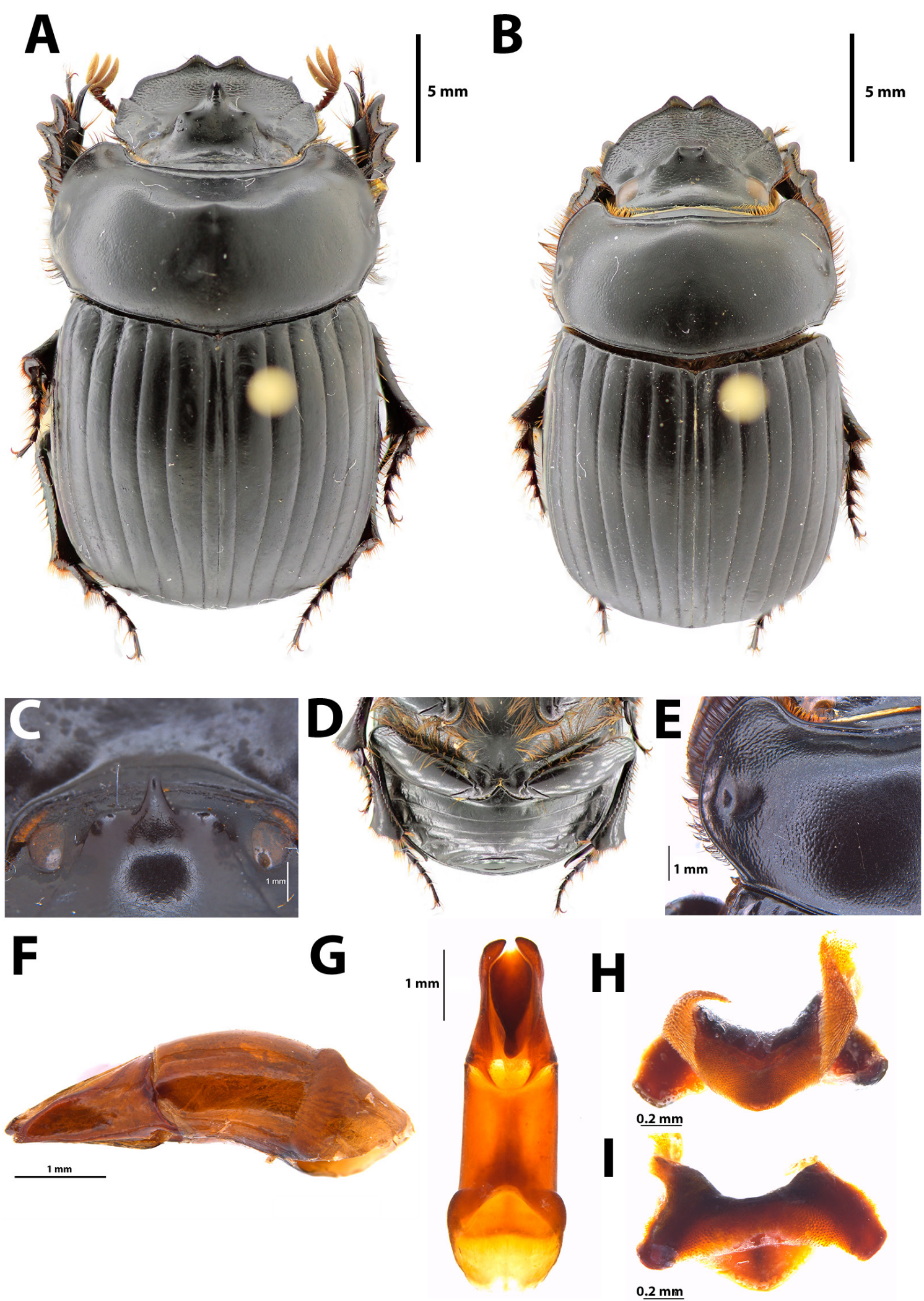

Fig. 11. Dichotomius inachoides (Felsche, 1901). A-B. Dorsal habitus. A. §. B. ․ . C. Frontal view of the head showing the male cephalic carina. D. Sternites smooth, lacking ocellate punctation. E. Female antero-lateral edge of the pronotum rugose. F. Lateral view of the aedeagus. G. Ventral view of the aedeagus. H-I. Lamella copulatrix. 
Legs. Metacoxa microsculpture shagreened, half of posterior portion covered by dense setigerous punctures.

Parameres and lamella copulatrix. As in Fig. 11F-H.

\section{Morphological variation}

Females (Fig. 11B, E)

As males except for the following characters:

HEAD. Surface rugose, becoming less dense on interocular space. Cephalic carina quadrituberculate, median tubercles higher than lateral.

Pronotum. Not modified, at most weak medial knob, visible laterally. Surface shagreened with firmly impressed punctures separated by diameter of a puncture, denser at anterolateral margins. Welldeveloped females exhibiting rugose surface next to antero-lateral fossae (Fig. 11E). Pygidium surface smooth, delimited by incomplete margin, faded apically.

\section{Remarks}

This seems to be an uncommon species as there are not many specimens in collections. The few found were unidentified. It is distributed throughout the Andes, more precisely on the east slope of the Andes mountain range. The key by Luederwaldt (1929) erroneously placed this species in the subgenus Cephagonus, section fissus. Examination of the holotype, based on the cephalic carina, suggests this species should have been placed in Luederwaldt's concept of the subgenus Selenocopris, now subgenus Luederwaldtinia, where the Dichotomius agenor species group is placed.

\section{Dichotomius (Luederwaldtinia) rafanunezi sp. nov. urn:lsid:zoobank.org:act:B221850A-C3E2-4AEF-A134-5CE0DB02DD3F}

Fig. 12, Map 7

\section{Diagnosis}

Dichotomius rafanunezi $\mathrm{sp}$. nov. is separated from other species in the group by the following combination of characters: dorsal and ventral surface shiny green to dark green. Anterior edge of pronotum displaying sharp declivity, antero-medial edge lacking well-developed lobes as D. fornicatus. Cephalic carina twice as wide as high, median and lateral tubercles narrow. Metasternum anterior edge surface rugose. $D$. rafanunezi sp. nov. also differs from $D$. fornicatus by shape of male genitalia (aedeagus and internal sac of aedeagus).

\section{Etymology}

Dichotomius rafanunezi sp. nov. is named after Rafael V. Nunez, a great scientist and friend who contributes to the study on Scarabaeinae and the genus Dichotomius.

\section{Material examined}

Holotype

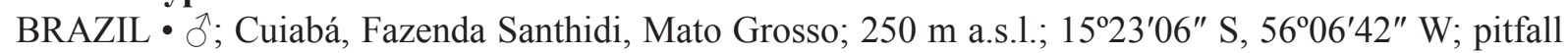
faeces; 8-11 Nov. 2008; L.R. Silva leg. [white, p]; CEMT.

\section{Paratypes}

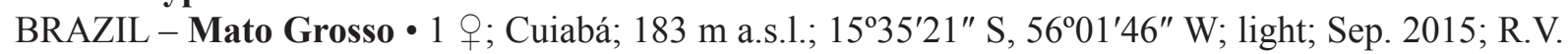

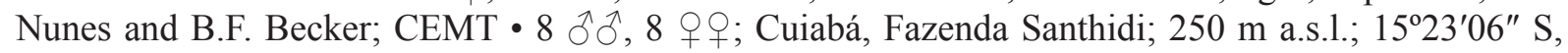
5606'42" W; pitfall faeces; 8-11 Nov. 2008; L.R. Silva leg.; CEMT • 1 ô, 2 우; Pitfall baço de boi; 5 Oct. 2008; L.R. Silva leg.; CEMT • 1 ô, 1 q; Cuiabá. Faz Santhidi; fruit trap; 30 Nov. 2008. L.R. 


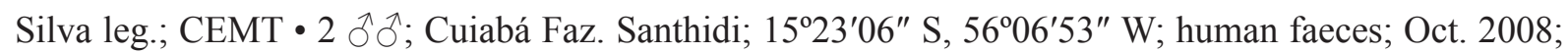
L.R. Silva leg.; CEMT • 1 ภ̂, 1 क; Cuiabá Faz. Santhidi; light; 4 Oct. 2008; L.R. Silva leg.; CEMT • 1 P; Cuiabá Faz. Santhidi; manual; 31 Oct. 2012; L.R. Silva leg.; CEMT • 1 đ̊; Cuiabá Faz. Santhidi; $15^{\circ} 23^{\prime} 06^{\prime \prime}$ S, 56 $06^{\prime} 53^{\prime \prime}$ W; FIT [flight interception trap]; 5-26 Oct. 2008; L.R. Silva leg.; CEMT • 1 ○;

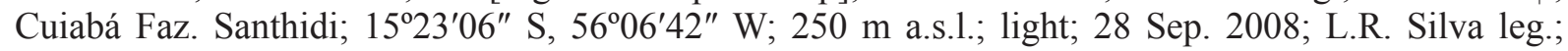
CEMT • 1 क; 3 Nov. 2008; L.R. Silva leg.; CEMT • 1 क; Fazenda Santhidi; pitfall human faeces; 3-11 Nov. 2008; R.F. Oliveira and L.R. Silva leg.; CEMT • 1 đ̊; Chapada dos Guimarães; manual; 7 Nov. 2011 spec.; Z. Hubner leg.; CEMT • 5 ổ ô; Diamantino Vale da Solidão; 14²2'14" S, 5607'59" W;

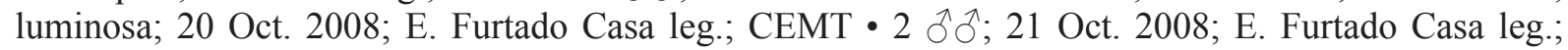

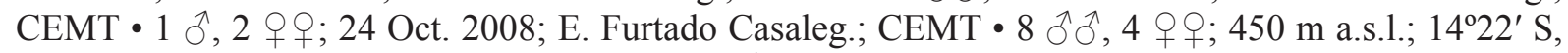
5607' W; Oct. 2012; E. Furtado leg.; CEMT • 1 गै; Alto Rio Arinos; Oct. 2001; E. Furtado leg.; CEMT • 1 §̊; Rosário Oeste Fazenda Cocal; manual; 19 Nov. 2012; S.E. Silva leg.; CEMT • 1 q; Poconé; manual; 17 Nov. 2011; S. Vianna leg.; CEMT.

\section{Description}

\section{Male}

MEASUREMENTS. Length: $13.61 \mathrm{~mm}$. Dorsal and ventral surface shiny green to dark green.

HEAD. Anterior surface rugose, extending posteriorly to middle third not reaching base of cephalic carina (Fig. 12A, C). Cephalic carina narrow, twice as wide as high and vertically broadened, anterior surface with small fine punctures. Median tubercle twice as high as lateral tubercles, conical in shape and slightly curved posteriorly; lateral tubercles obtuse apically. Ventral clypeal process obtuse.

Pronotum. Wider than long. Pronotal disc shiny covered by dense deep punctures, separated by width of a puncture. Anteromedial edge with distinct declivity, antero-lateral margins rugose (Fig. 12A). Hypomeron medial disc smooth and shiny. Lateral edge margin bearing single row of setae, all approximately of same length.

ABDomen. Prosternum and mesosternum surface shagreened, bearing round ocellate punctures of same size as on hypomera, punctures separated by width of a puncture (Fig. 12D). Metasternum antero-median portion next to mesocoxa rugose (Fig. 12H), with ocellate punctures along lateral areas separated by diameter of a puncture. Small ocellate punctures surrounding margins of mesocoxa. Ocellate punctures along antero-lateral margins sternites, larger on lateral edges. Sixth abdominal sternite and apex of the pygidium lower or depressed than other sternites. Pygidium delimited by margin that widens towards apex, surface covered by well-impressed punctures and basal margin bearing few scattered punctures that merges together.

ELYTRA. Opaque, wider than long. Interstriae microsculpture shagreened, fine shining punctures arranged randomly. Striae black, punctures weakly impressed but clearly defined, separated by twice diameter of a puncture on elytral disc (Fig. 12A).

LEGS. Metacoxa posterior edge bearing row of disorganized small, ocellate glabrous punctures, separated by width of a puncture. Setigerous punctures next to insertion of trochanter large, approximately twice width of smaller punctures.

Parameres and lamella copulatrix. As in Fig. 12E-G.

\section{Morphological variation}

Females (Fig. 12B)

As males except for the following characters:

HEAD. Surface completely rugose, denser at anterior portion. Cephalic carina trituberculate, median tubercle higher than lateral and medially emarginate. Lateral tubercles narrow. 

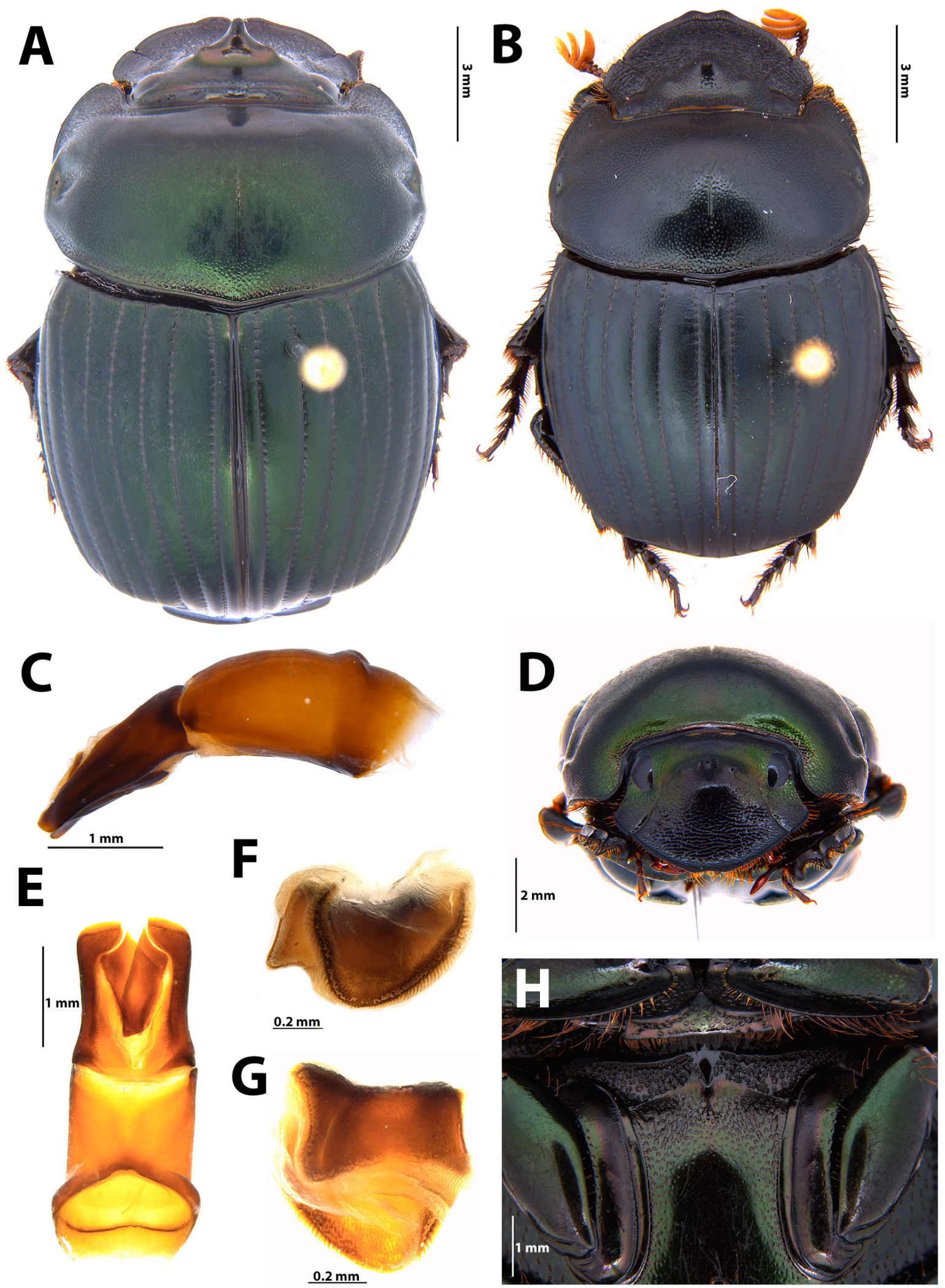

Fig. 12. Dichotomius rafanunezi sp. nov. A-B. Dorsal habitus. A. Holotype, $\widehat{\jmath}$ (CEMT). B. $\uparrow$. C. Lateral view of the aedeagus. D. Frontal view of the head. E. Dorsal view of the aedeagus. F-G. Lamella copulatrix. H. Ventral view of the metasternum; antero-medial edge near the interior margin of the mesocoxa rugose. 
PRonotum. Weak medial depression on anterior edge, surface covered by well-impressed punctures, separated by width of a puncture. Median sulcus conspicuous.

\section{Remarks}

This species occurs from Mato Grosso, central west Brazil, and is closely related to D. fornicatus (Luederwaldt, 1931).

Dichotomius (Luederwaldtinia) sagittarius (Harold, 1869) stat. rev.

Fig. 13, Map 9

Pinotus sagittarius Harold, 1869 (original description).

Pinotus sagittarius - Luederwaldt 1929: 99. — Blackwelder 1944: 208.

Dichotomius amplicollis - López-Guerrero 2005: 196.

Dichotomius sagittarius stat. rev. is separated from other species in the group by the following combination of characters: head cephalic carina median tubercle approximately twice as high as lateral ones, conical in shape, weakly curved posterially and never bifurcated at apex. Anterior disc of the pronotum displaying moderate declivity, not abrupt and truncated as in D. agenor and D. amplicollis. External margin of hypomeron bearing multiple rows of disorganized long setae. Metacoxa posterior edge with single row of ocellate punctures, punctation never merges. Elytral interstriae shagreened.

\section{Material examined}

Lectotype (here designated)

MEXICO • ${ }^{7}$; "Toxpam P. sagittarius Harold." [white with red margins, hw]/ "Ex-Musaeo E. Harold" [white with black margins, p]; MNHN.

Paralectotypes $(2 \hat{\jmath} \hat{o}, 1 \stackrel{+}{)})$

MEXICO • ${ }^{\text {; }}$ "Mexique Pinotus sagittarius Chevrol." [white, hw]/ "Ex-Museaeo E. Harold/PARALECTOTYPE + Pinotus sagittarius Harold des. F.Z. Vaz-de-Mello, 2014" [yellow with black margin, phw]; MNHN • ${ }^{\lambda}$; "Type" [white, rounded with red margins]/"Cordova"[white, p]/ "Mexico Sallé Coll." [white, p]/“B.C.A. p. 52 sp.4" [white, phw]/ "Pinotus sagittarius Type Harold apud Sallé" [white, hw]/"NHMUK 010847040 [white, p]; BMNH - J; "Type" [white, rounded with red margins]/ "Cordova" [white, p]/“Mexico Sallé Coll." [white, p]/B.C.A. p. 52 sp.4 [white, phw]/ 720 [green, p]/Pinotus sagittarius Type Harold apud Sallé [white, hw]/P. Sagittarius Harold. [white, hw]/TYPE SAGITTARIUS HAROLD det. F. Génier, 2008 [white with black margins, phw]/PARALECTOTYPE [yellow with black margins, p]/ "NHMUK 010847041" [white, p]; BMNH.

\section{Additional material}

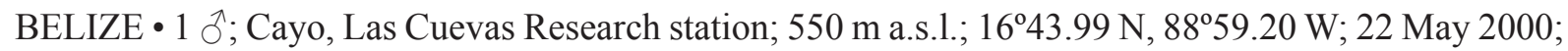

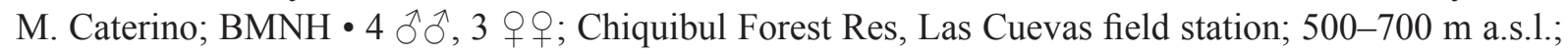
88 59' W; 16²4' N; May-Jun. 1997; D. Inward leg.; BMNH 2005-78.

MEXICO • 1 ○; Fry leg.; BMNH 1905-100 • 1 क; Fry leg.; BMNH 1905-100 • 1 q ; Curtis leg.; BMNH.

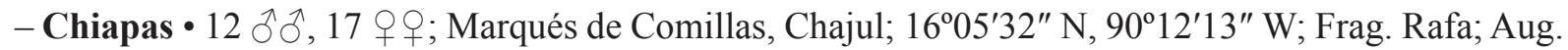
2005; G. Ponce leg.; CEMT. - Oaxaca • 2 đð’; Santa María Chimalapa; 187 m a.s.1.; 1655'27.2" N,

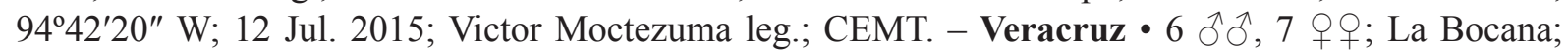
human faeces; 26 Jul. 1996; CEMT • 1 q; Fortín; 1-4 Oct. 1967; E. Greenwood leg.; CEMT. - San Luis $\bullet 1$ Oे; 3 mi. W of El Naranjo; 1100 m a.s.l.; 10-18 Jun. 1971; A. Newton leg.; CEMT. 


\section{Redescription}

Male

MEASUREMENTS. Length: $20.43 \mathrm{~mm}$.

HEAD. Anterior surface rugose, not extending posteriorly to base of cephalic carina. Cephalic carina wider than high. Median tubercle twice as high as lateral tubercles. Median tubercle conical in shape, weakly curved, apically obtuse and never bifurcate (Fig. 13C). Inter-ocular space shiny, smooth and surrounded by small shallow punctures. Ventral clypeal process truncate and expanded distally (see Fig. 2B).

Pronotum. Wider than long and wider than elytra. Anterior disk with moderate declivity, anterolateral surface next to fossae with fine punctures. Row of interrupted ocellate punctures along Pronotal margins, denser on anterior and posterior margins (Fig. 13A). Pronotal medial disc shiny, covered by fine punctures. Hypomeron disc smooth, lacking punctures. External margin bearing multiple rows of disorganized long setae, all approximately of same length (see Fig. 2E).

ABdomen. Mesosternum and metepisternum covered by dense ocellate setigerous punctures. Metasternum setigerous punctures restricted mainly to lateral and anterior areas of mestasternal lobe. Pilosity of antero-median portion connecting with lateral through margin of mesocoxa (see Fig. 2G). Metasternum lateral surface, with ocellate setigerous punctures separated by three times width of a puncture. Ocellate punctures along anterior margins of each sternite, denser in lateral sides, medial portion smooth. Pygidium basal margin bearing some ocellate punctures.

ELYTRA. Interstriae shagreened with fine, randomly separated punctures. Striae clearly marked, with ocellate punctures separated by diameter of a puncture on elytral disc (Fig. 13A).

LEGS. Metacoxa posterior edge bearing single row of organized setigerous punctures, separated between them by one time diameter of a puncture, punctures never merge together (Fig. 13D).

Parameres and lamella copulatrix. As in Fig. 13E-G.

\section{Morphological variation}

Females (Fig. 13B)

As males except for the following characters:

HEAD. Surface completely transversely rugose, denser on anterior portion. Cephalic carina quadridentate, feebly elevated.

Pronotum. Weak medial knob discernible on lateral view, punctures denser and deeply impressed laterally.

ELYTRA. Striae, thinner with small punctures separated by twice diameter of a puncture on elytral disc.

\section{Remarks}

Dichotomius sagittarius stat. rev. was synonymized with D. amplicollis by López-Guerrero (2005). A detailed examination of the lectotype led us to conclude that $D$. sagittarius stat. rev. should be revalidated, as there are clear differences between the types and recently collected specimens of both species. The distribution of this species follows areas of dry forests of the Gulf of Mexico and the Yucatán peninsula across the Mexican east coast (Morrone 2001). According to Morrone (2001), these two areas are ecologically similar and comparable with areas in the province of Chiapas and the east and south of the Sierra Madre, suggesting that it is highly probable that $D$. sagittarius stat. rev. will be found in those areas. 

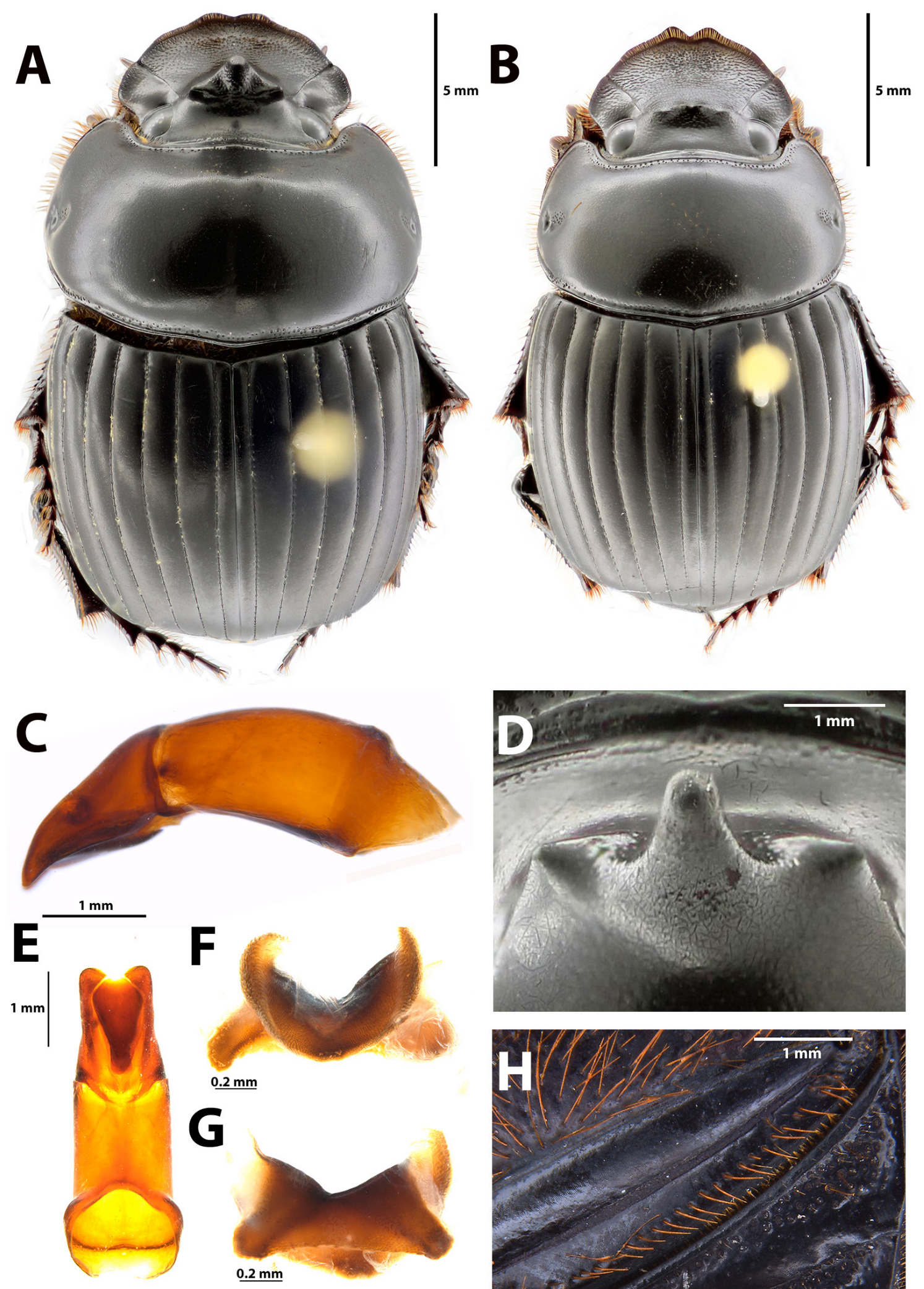

Fig. 13. Dichotomius sagittarius (Harold, 1869) stat. rev. A-B. Dorsal habitus. A. ̊̊. B. ๆ. C. Lateral view of the aedeagus. D. Anterior view of the cephalic carina. E. Ventral view of aedeagus. F-G. Lamella copulatrix. H. Ventral view of the metacoxa, displaying on the posterior margin a single row of organized ocellate setigerous punctures. 
Dichotomius (Luederwaldtinia) simplicicornis (Luederwaldt, 1935)

Fig. 14, Map 12

Pinotus simplicicornis Luederwaldt, 1935: 340 (original description).

Pinotus simplicicornis - Blackwelder 1944: 208.

Dichotomius simplicicornis - Ratcliffe et al. 2015: 197. — Chamorro et al. 2018: 95; 2019: 132.

\section{Diagnosis}

Dichotomius simplicicornis is separated from other species in the group by the following combination of characters: cephalic carina median tubercle higher than lateral ones, apically rounded and emarginate. Lateral tubercles short with acute on apex. Ventral clypeal process conical apically acute. Pronotum medial edge of the anterior disc declivity deeper than lateral sides, resembling two underdeveloped lobes. Elytral striae well marked, punctuation same width of striae; interstriae smooth.

\section{Material examined}

Lectotype (head and pronotum, here designated)

PERU • \’ "Peru” [white, hw]/ "Pinotus simplicicornis n. sp. Lueder. Det. 1934” [white, hw]/ "Fry Coll. 1905-100” [white, p]/ “34600” [white, hw]/ "HOLOTYPE” [red with black margins, p]; BMNH.

\section{Additional material}

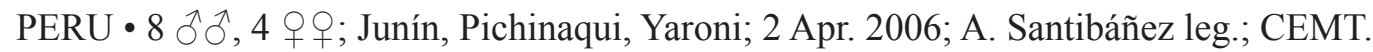

\section{Redescription}

\section{Male}

MEASUREMENTS. Length: $20.17 \mathrm{~mm}$.

HEAD. Anterior third surface transversely rugose, extending posteriorly not reaching base of cephalic carina. Interocular space smooth, with scattered deep punctures (Fig. 14C-D). Clypeal margin with large medial emargination separating two rounded clypeal teeth feebly angled upwards. Cephalic carina, wider than high and conical in shape (Fig. 14D). Median tubercle three times as high as lateral tubercles, apically rounded and emarginate. Lateral tubercles short and acute on apex (Fig. 14C). Ventral clypeal process conical in shape and apically acute.

Pronotum. Twice as wide as it is long, wider than elytra. Pronotal disc shiny and with well-impressed simple punctures, larger punctures on anterolateral edges and near posterior basal central margin. Anterior disc with sharp declivity, medial portion deeper than lateral sides, resembling two underdeveloped lobes (Fig. 14A, D). Hypomeron medial disc smooth and shiny, external margin bearing rows of disorganized setigerous punctures, setae all approximately of same length (see Fig. 2E).

AвDOMEn. Prosternum surface shagreened, with scattered ocellate setigerous punctures. Mesosternum and metepisternum surface shagreened, with large ocellate setigerous punctures, separated by less than twice diameter of a puncture. Metasternum anterior surface and margins of mesocoxa microsculpture shagreened, covered by dense long setae that surrounds the margins of mesocoxa, joining the anteromedial with lateral portions of metasternum (see Fig. 2G). Longitudinal sulcus distinctly sculpted, ending as shallow mid-fossa. Sternites with ocellate punctures along anterior margins. Pygidium delimited by incomplete margin, faded apically, large punctures restricted to basal margin, medial and apical surfaces finely punctate. 

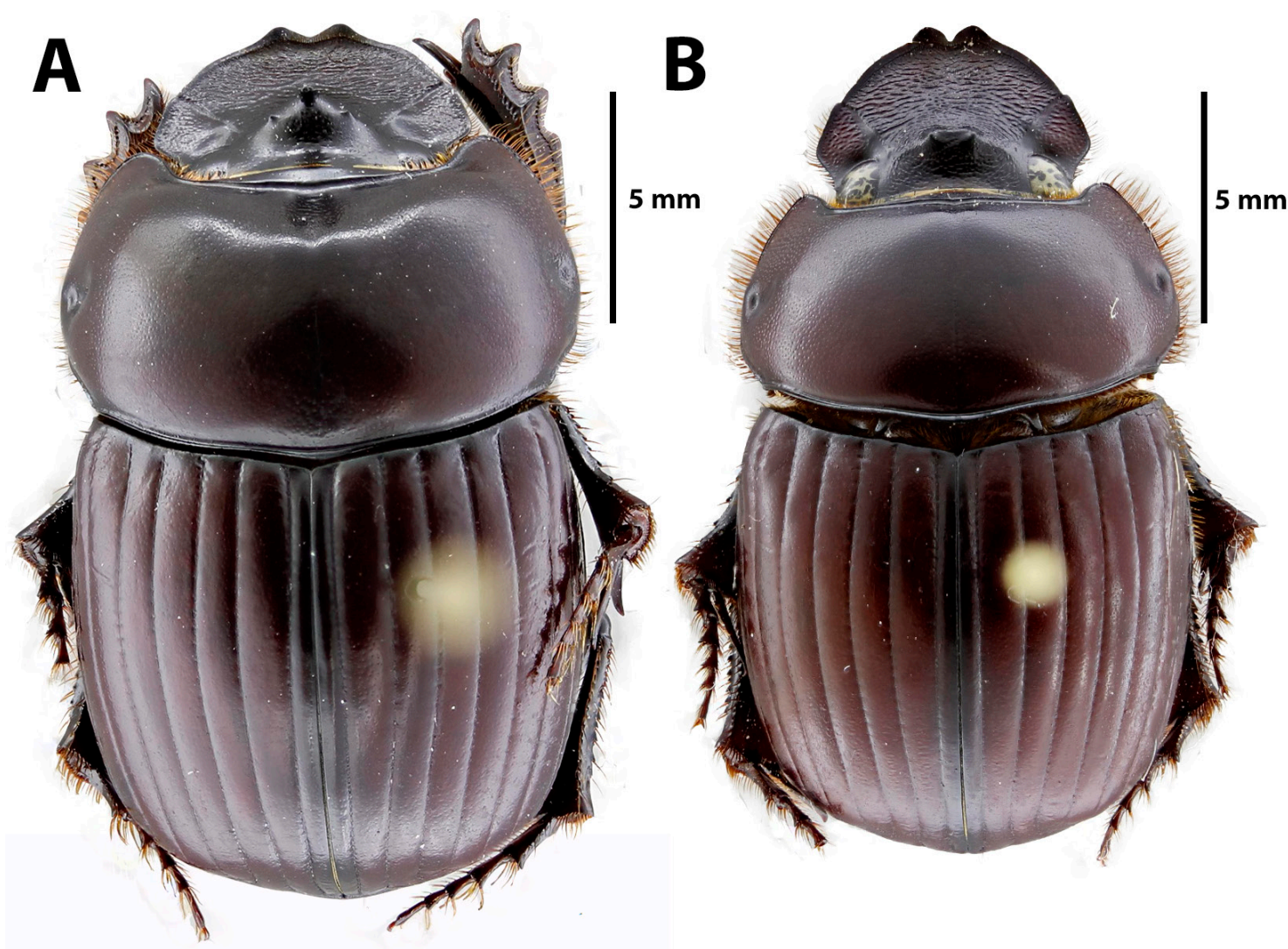

C
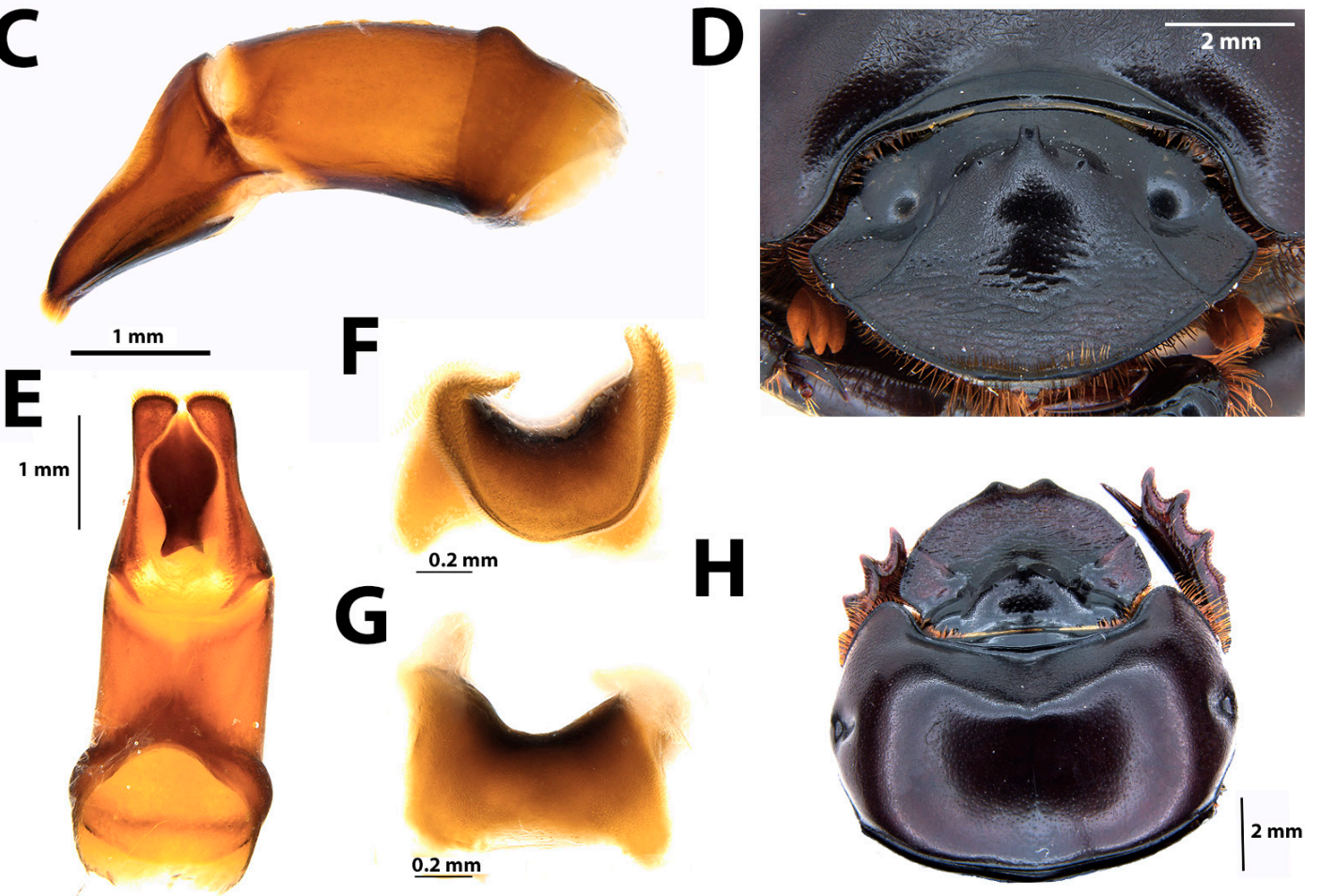

Fig. 14. Dichotomius simplicicornis (Luederwaldt, 1935). A-B. Dorsal habitus. A. §. B. ․ . C. Lateral view of the aedeagus. D. Frontal view of the male head, cephalic carina apically rounded, emarginate, lateral tubercles short and acute on the apex. E. Ventral view of the aedeagus. F-G. Lamella copulatrix. H. Pronotum arcuate viewed from above, anterior edge declivity resembling two under-developed lobes at the sides. 
ELYTRA. Shiny, wider than long. Striae distinctly punctate separated by two times diameter of a puncture on elytral disc; punctures same width of striae. Interstriae smooth with conspicuous randomly arranged punctures.

LEGS. Metacoxa microsculpture shagreened, posterior edge covered by row of dense setigerous punctures separated by less than diameter of a puncture, setae dense. In ventral view, profemora surface with scattered well-imprinted punctation, setigerous punctation restricted to medial edge.

Parameres and lamella copulatrix. See Fig. 14E-G.

\section{Morphological variation}

\section{Females (Fig. 14B)}

As males except for the following characters:

HEAD. Surface completely rugose. Space between clypeal teeth less separated than in males. Genae border protruding clypeal margin. Fronto-clypeal carina bituberculate.

Pronotum. Narrower than elytra, gibbous.

ElYTRA. Twice as long as pronotum with shagreened microsculpture.

\section{Remarks}

The holotype has the first half of the body (head and pronotum) of a male and the second half (abdomen) of a female. As the ICZN states in Article 73.1.5 "If a subsequent author finds that a holotype which consists of a set of components (e.g. disarticulated body parts) is not derived from an individual animal, the extraneous components may, by appropriate citation, be excluded from the holotype (material may be excluded from a hapantotype if it is found to contain components representing more than one taxon"; therefore, we here designate the head and the pronotum as lectotype. Endemic species from Peru and individuals cited by Chamorro et al. $(2018: 95,2019$ : 132) from Ecuador were the rare species Dichotomius foveicollis (Kirsch, 1871).

Dichotomius (Luederwaldtinia) subaeneus (Castelnau, 1840)

Fig. 15, Map 13

Copris subaenea Castelnau, 1840: 79 (original description).

Pinotus subaeneus - Luederwaldt 1929: 136. — Blackwelder 1944: 208.

Dichotomius subaeneus - Larsen 2011: 92.

\section{Diagnosis}

Dichotomius subaeneus is separated from other species in the group by the following combination of characters: copper colour. Sparse or absence of setae on body surface. Cephalic carina narrow, wider than high. Ventral clypeal process greatly emarginate. Pronotum not modified. Elytra striae displaying strong, well-imprinted punctuation separated between them by one time diameter of a puncture on elytral disc. Protibia apical spine bifurcate.

\section{Material examined}

Lectotype ( $\partial$, here designated)

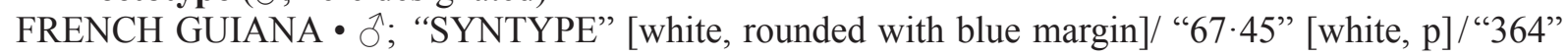
[grey, hw]/"subaeneus Dej. Cayenne" [white, hw]/"subaeneus Cast. J. Gillet. det. 1912" [white, phw]/“LECTOTYPE" [red with black margin, p]/ "Copris LECTOT. subaenea Cast. det, F. Vaz-deMello, 2011”/ "NHMUK 010847024" [white, p]; BMNH. 


\section{Additional material}

BRAZIL - Amazonas • 7 q $q$; 90 km N Manaus; Nov. 1997; E. Andressen leg.; CEMT • 2 q $q$; Res. Florest. Ducke, 26 km E of Manaus, Am. [Amazonas]; 4-12 Mar. 1966; W.D. Edmonds leg.; CEMT • 1 q; Manáos, Rio Negro, Amaz. [Amazonas]; 17 Dec. 1927; CEMT. - Pará • 1 q; Monte Dourado, Reserva do Pacanari; 180 m a.s.1.; 0 $38^{\prime}$ S, 52 $2^{\circ} 34^{\prime}$ W; rainforest, dung pitfall trap; Apr.-May 2005; T.A. Gardner and M.I.M. Hernández leg.; CEMT • $2 \widehat{\jmath}, 5$ 우; Monte Dourado, Reserva do Pacanari; $180 \mathrm{~m}$ a.s.1.; $0^{\circ} 38^{\prime} \mathrm{S}, 52^{\circ} 34^{\prime} \mathrm{W}$; rainforest, dung pitfall trap; Apr.-May 2005; T.A. Gardner and M.I.M. Hernández leg.; BMNH・1 đơ; Tucuruis, 8.84, Rio Tocantins; N. Degallier leg.; CEMT.

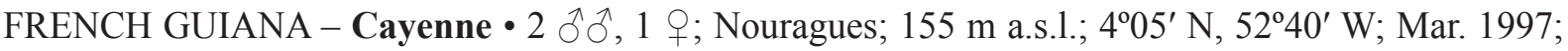

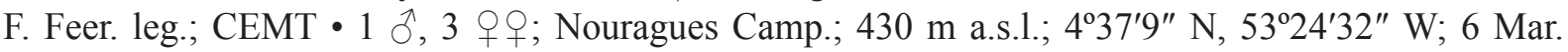

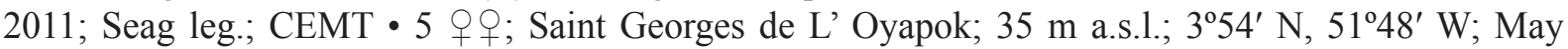
2014; F. Feer. leg.; CEMT. - Guyane • 1 J , 6 우; Sain Eugène, Barrage de Petit Saut; 90 m a.s.l.;

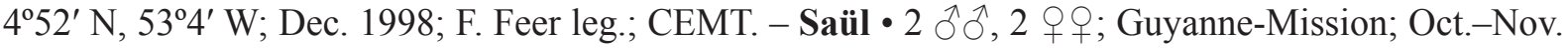
1969; Balachowsky-Gruner leg.; CEMT 2 đิ ô, 6 우; Saint Laurent du Maroni, Bélvédère de Saül;

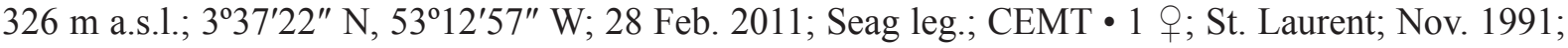
P. Arnaud leg.; CEMT.

GUIANA • 1 §; Oronque and New River Head; 1938; 1938-346; H. Bedding B.M; BMNH • 1 \%; New River; Mar.-May 1938; C.A. Hudson leg.; BMNH.

\section{Redescription}

\section{Male}

MEAsuREMENTs. Length: $20.8 \mathrm{~mm}$. Dorsal and ventral surface copper to dark copper, shiny with olive green reflection. Body with setae sparse or absent.

HEAD. Anterior surface rugose extending posteriorly not reaching base of cephalic carina. Cephalic carina narrow, wider than high; anterior surface smooth with scattered punctures. Median tubercle one and half times as high as lateral tubercles which are rounded apically. (Fig. 15A). Ventral clypeal process greatly emarginate (Fig. 2C).

Pronotum. Twice as wide as long and as wide as elytra. Anterior disc declivity weak. Pronotal medial disc shiny, with fine well-impressed punctures. Antero-lateral fossae with ocellate punctures. Ocellate punctures along anterior and posterior margins, never on lateral. Hypomeral disc smooth, without punctures; external margin bearing single row of organized long setae visible in dorsal view.

ABDOMEN. Prosternum surface microsculpture shagreened, glabrous. Mesosternum surface microsculpture shagreened with ocellate setigerous punctures, setae short. Metepisternum surface smooth, displaying setigerous punctures. Metasternum antero-medial edge with superficial weak marked punctuation next to apical margins of mesocoxa (Fig. 15D); ocellate punctation restricted mainly to lateral edges, few setigerous punctures near metepisternal suture. Ocellate punctures along anterior margins of each sternite, denser in lateral areas and medially vanished. Pygidium surface displaying well-impressed simple punctures, basal margin with wide ocellate punctures.

ELYTRA. Interstriae smooth, shiny with fine randomly separated punctures. Striae well delimited and distinctly punctate, punctures wider than striae and separated by twice diameter of a puncture on elytral disc.

LEGS. Metacoxa glabrous, fore calcar bifurcate (Fig. 15C).

Parameres and lamella copulatrix. As in Fig. 15E-F. 

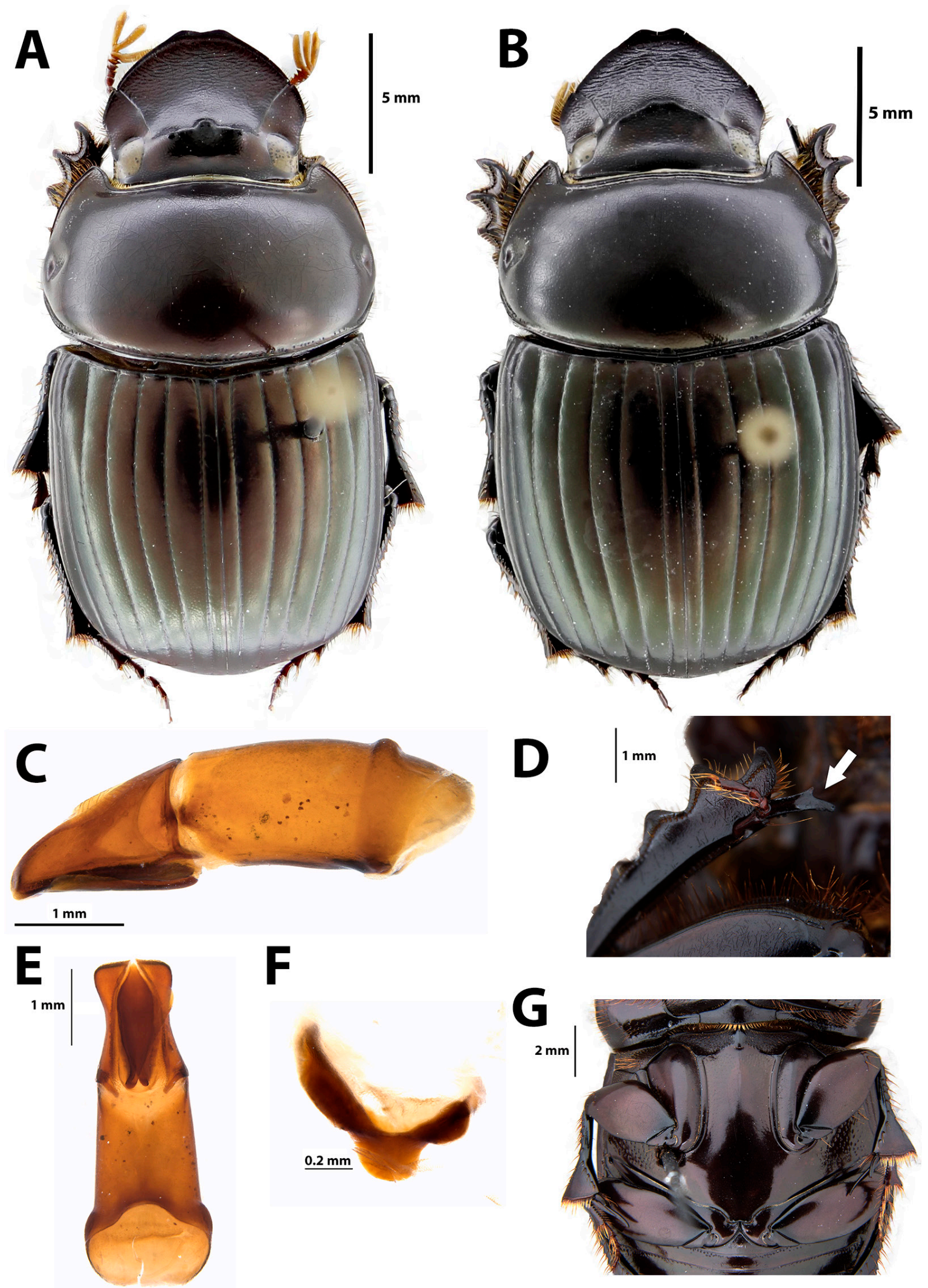

Fig. 15. Dichotomius subaeneus (Castelnau, 1840). A-B. Dorsal habitus. A. $\widehat{\jmath}$. B. + . C. Lateral view of the aedeagus. D. Protibial calcar spine bifurcate. E. Ventral view of the aedeagus. F. Lamella copulatrix. G. Metasternum pilosity sparse, some few setae on the lateral edges. 


\section{Morphological variation}

Females (Fig. 15B)

As males except for the following characters:

HEAD. Clypeus elongate. Anterior surface completely rugose, interocular surface with well-impressed flat punctures separated by twice diameter of a puncture. Cephalic carina quadri-dentate, triangular in shape. Median tubercles located forward lateral tubercles.

Pronotum. Shiny, with fine well-impressed punctures, denser on antero-lateral sides.

AвDOMEN. Prosternum antero-medial edge with vertical rugosity.

LEGS. Profemur distal setae dense.

\section{Remarks}

This species is easily distinguished by its copper colour and sparse pilosity. As with D. belus, the protibial calcar spine is bifurcate. Luederwaldt (1929) mentioned the similarity of these two species to D. cuprinus (Felsche, 1901) and transferred it from the inachus group to the carbonarius group. After a detailed inspection of the lectotype and other specimens, we suggest that this species belongs to the D. agenor species group based on the shape of the cephalic carina.

Dichotomius (Luederwaldtinia) triquetrus (Luederwaldt, 1923)

Fig. 16, Map 14

Pinotus triquetrus Luederwaldt, 1923:11 (original description).

Pintous triquetrus - Blackwelder 1944: 208.

Dichotomius triquetrus - Schoolmeesters 2018 (Catalogue of Life).

\section{Diagnosis}

Dichotomius triquetrus is separated from other species in the group by the following combination of characters: dorsal and ventral surface reddish to dark brown. Anterior clypeal margin with deep emargination separating two obtuse teeth. Head interocular space displaying flat punctures, resembling rough; distinct ocellate punctuation near eyes. Pronotum medial disc with fine punctures, anterolateral edges with well-impressed punctures, ocellate punctuation along margins. Elytra striae strongly marked, interstriae microsculpture shagreened

\section{Material examined}

Lectotype (here designated)

TRINIDAD AND TOBAGO • + ; “Caparo Trinidad Heyne, Berlin-Wilm.” [white, p] / "Pinotus triquetrus n. sp. Lüd.det.23” [white, hw]/ "18188” [white, p]/ [blue rounded label]; MZSP.

\section{Additional material}

TRINIDAD AND TOBAGO • 1 o, 1 क; St. George Co., Range, Simla Research Station, Arima Valley, N. Range; $800 \mathrm{ft}$ a.s.1.; $10^{\circ} 41^{\prime} 34^{\prime \prime} \mathrm{N}, 61^{\circ} 17^{\prime} 22^{\prime \prime} \mathrm{W}$; FIT [flight interception trap]; premontane tropical rainforest; 3 Jun. 2000; S. Alistair and Ramsdale leg.; CEMT • 1 क; Trinidad; 1904; F. Birch leg.;

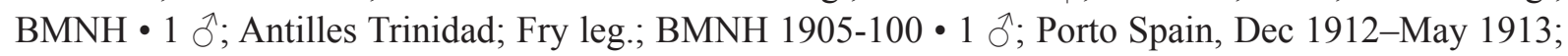
R. Thaiter leg.; MZSP. 
VENEZUELA $・ 1$ ภ̊; BMNH.

COUNTRY UNKNOWN• 1 \%; Nevinson leg.; BMNH 1918-14.

\section{Redescription}

\section{Female}

MEAsurements. Length: $17.89 \mathrm{~mm}$. Dorsal and ventral surfaces reddish to dark brown.

HEAD. Anterior edge surface horizontally rugose, interocular space displaying flat punctures, resembling rough; distinct ocellate punctuation near eyes. Clypeus with central deep emargination separating two acute clypeal teeth (Fig. 16B-C). Cephalic carina bituberculate, wider than high, tubercles obtuse apically (Fig. 16C). Ventral clypeal process truncate (see Fig. 2B).

Pronotum. Gibbous, wider than long. Pronotal anterior disc shiny and smooth with fine, dense and wellimpressed punctures near antero-lateral sides. Uninterrupted ocellate punctures along pronotal margins (Fig. 16B, D). Hypomeral disc punctate; external margin bearing single row of organized long setae, approximately of same length (see Fig. 2F).

Aвdomen. Prosternum surface with fine microsculptured, glabrous. Mesosternum and metepisternum surface microsculpture shagreened with ocellate setigerous punctures. Metasternum setigerous punctures restricted mainly to anterior and lateral edges of mestasternal lobe, puncture diameter variable. Punctuation of antero-median edge connecting with lateral ones through margin of mesocoxa (see Fig. 2G). Lateral edges of metasternum with ocellate, setigerous punctures separated by width of a puncture, pilosity sparse, setae short, not reaching metepisternum suture. Longitudinal sulcus clearly visible. Ocellate punctures along anterior margins of sternites. Pygidium ocellate punctation on basal edge and through lateral margins.

ELYTRA. Interstriae microsculpture shagreened (see Fig. 2J), fine punctures randomly distributed. Striae strongly marked, ocellate punctures separated by diameter of a puncture on elytral disc (Fig. 16D).

LEGs. Metacoxa posterior edge bearing single row of organized ocellate punctures, separated by diameter of a puncture. Posterior margin of meta-trochanter with long setae.

\section{Morphological variation}

Males (Fig. 16A) are distinguished from females as follows:

HeAD. Cephalic carina higher than wide, conical in shape. Median tubercle twice as high as lateral tubercles, rounded, weakly bifurcate apically and curved posteriorly. Apex of lateral tubercles acute.

Pronotum. Surface covered by fine punctures, denser at antero-lateral areas; anterior disc with weak declivity.

Parameres and lamella copulatrix. As in Fig. 16E-G.

\section{Remarks}

This is an endemic species from Trinidad. The redescription was based on the well-developed female of the MZSP and the underdeveloped female at the CEMT. The male redescription was based on the specimen in the MZSP wrongly determined by Pereira as "Pinotus belus" and an underdeveloped male from the CEMT. Male genitalia were extracted from the underdeveloped male at CEMT. Luederwaldt (1923) also mentioned a male specimen in the type series that could not be traced. 

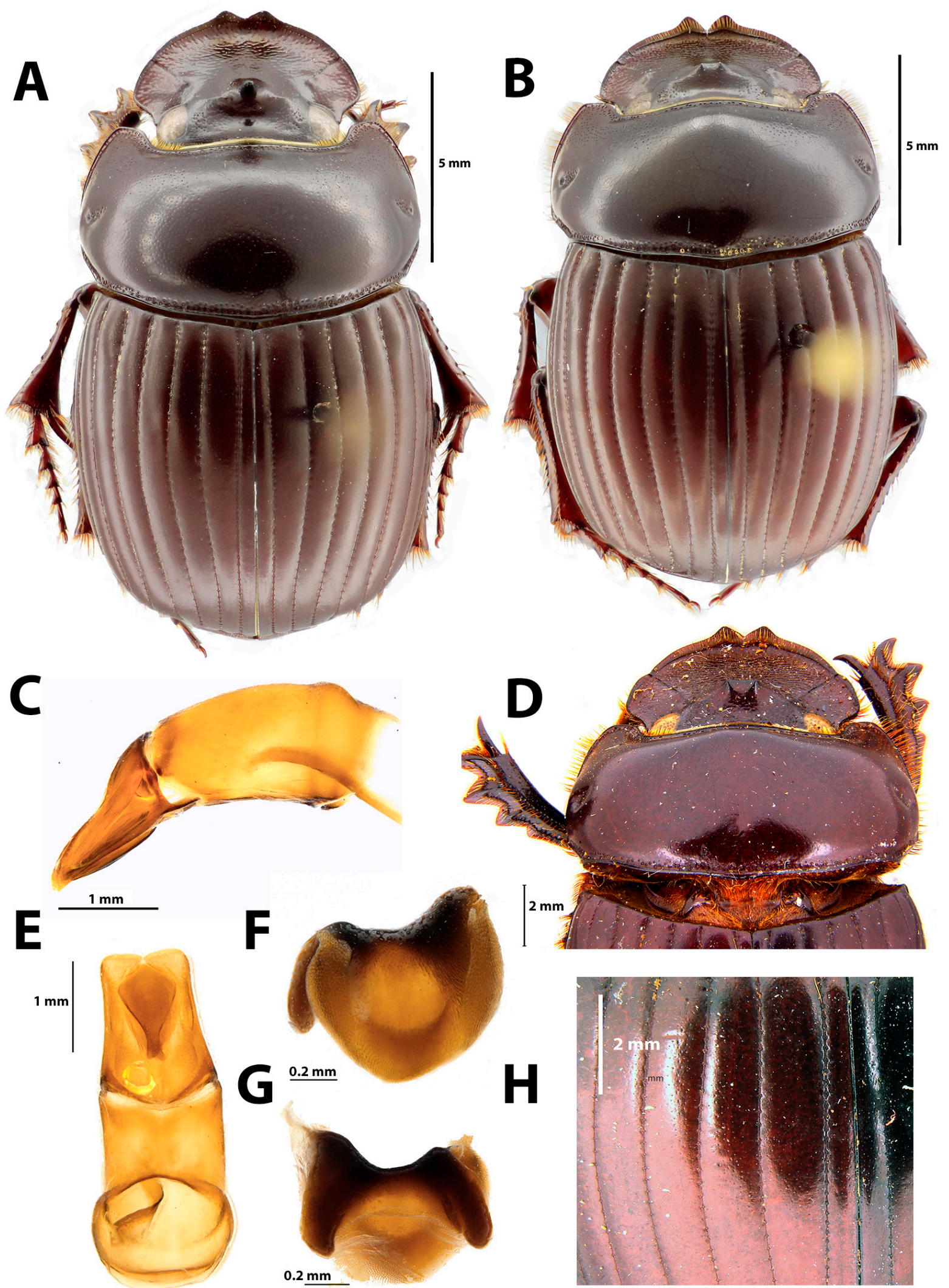

Fig. 16. Dichotomius triquetrus (Luederwaldt, 1923). A-B. Dorsal habitus. A. $\widehat{\jmath}$. B. $q$. D. Lectotype, $q$ (MZSP). C. Lateral view of the aedeagus. D. Dorsal view of the head. E. Ventral view of the aedeagus. F-G. Lamella copulatrix. H. Elytra. 
Dichotomius (Luederwaldtinia) tristis (Luederwaldt, 1923)

Fig. 17, Map 10

Pinotus tristis Luederwaldt, 1923: 12 (original description).

Pinotus tristis - Blackwelder 1944: 208.

Dichotomius tristis - Roze 1955: 44.

\section{Diagnosis}

Dichotomius tristis is separated from other species in the group by the following combination of characters: median tubercle of cephalic carina weakly curved posteriorly and rounded-truncate on apex. Apex of lateral tubercles obtuse. External margin of hypomeron bearing single row of long setae. Metasternal lateral pilosity sparse. Metacoxae with single row of organized ocellate punctures.

\section{Material examined}

Holotype

VENEZUELA • ○’; "VENEZUELA. 11.74" [white, hw]/ "HOLOTIPO" [red with black margins, p]/ "Pinotus $\widehat{O}$ tristis Lüd. Lüd. Det. 23." [white, hw]/“18150" [white, p]; MZSP.

\section{Additional material}

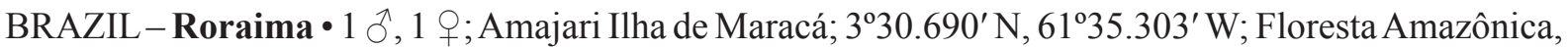
Pitfall with human faeces; 9 May 2009; R. Andrade leg.; CEMT 3 ỗ 3 우; Serra da Moça; primary forest; Jul. 1997; F.Z. Vaz-de-Mello leg.; CEMT.

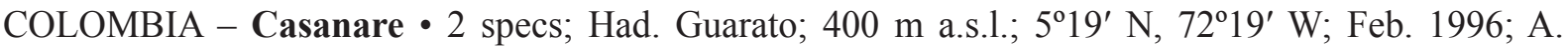
Lopera leg.; ECC • 2 specs; Pore, Vda. Altamira, Fca. La Esperanza; 350 m a.s.1.; 542'26" N, 76 $6^{\circ} 3^{\prime \prime}$ " W; Oct. 2006; I. Quintero and L.E. Franco leg.; IAvH. - Cundinamarca - 1 spec.; Paratebueno, Fca. Palumea; 232 m a.s.1.; 4 20'18.5" N, 73¹1'44.3" W; 26 Jan. 2013; J.S. Cardenas leg.; IAvH. - Guaviare • 1 spec.; San José del Guaviare, Fca. Eli; 200 m a.s.1.; Aug. 2016; A. Santos leg.; ECC. - Meta • 36 specs; Acacias, Fca. Buenavista; 494 m a.s.1.; 357.534' N, 73²41.951' W; Aug. 2012; L.M. Isaza leg.; IAvH • 89 specs; Barranca de Upía, Fca. Guaycaramo; 194 m a.s.1.; 4²6'9.9" N, 7258'18.4" W; 14 Mar. 2013; J.S. Cardenas leg.; IAvH • 86 specs; El Dorado; 336 m a.s.l.; $3^{\circ} 42.34^{\prime}$ N, $73^{\circ} 32.56^{\prime}$ W; Llanos orientales; Aug. 2012; L.M. Isaza leg.; IAvH • 1 §; Mozambique, Franja Bosque de galleria; 190 m a.s.1.; Apr. 1996; Jorge A. Noriega leg.; CEMT -2 specs; PNN, Tinigua, Rio Duda; 350 m a.s.1.; $2^{\circ} 40^{\prime} \mathrm{N}, 74^{\circ} 10^{\prime} \mathrm{W}$; Jan. 996; I. Jiménez leg.; IAvH • 1 spec.; Puerto López, El Naranjal; 220 m a.s.1.; 45'14" N, 7257'30" W; Feb. 1997; F. Escobar leg.; IAvH • 116 specs; San Martín, Fca. La Laguna; 326 m a.s.1.; 342.251' N, 73³2.33' W; Sep. 2012; L.M. Isaza leg.; IAvH • 1 spec.; San Martín, Nuevo Caney; 389 m a.s.1.;

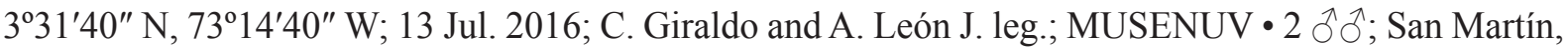
Had. Tocancipá; 335 m a.s.l.; Sabana-Bosque; Apr. 2006; J. Noriega leg.; CEMT • 1 spec.; Remolino, Cafam Llanos; 200 m a.s.l.; Apr. 1996; A. Lopera and S. Amézquita leg.; ECC • 2 specs; Villavicencio, Via Pto. Colombia; 150 m a.s.1.; 4²'91" N, 7578'15" W; Mar. 1998; A. Camacho leg.; IAvH. - Vaupés •

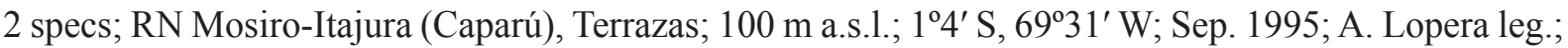

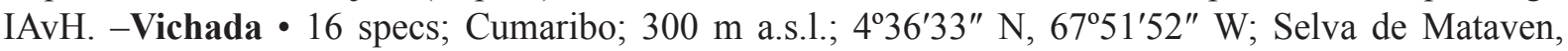
bosque de cerro rocoso; 6 Mar. 2007; L.E. Franco leg.; IAvH.

VENEZUELA - Amazonas • 1 +; 150 m a.s.1.; Aug. 2003; CEMT • 1 \%; Atures, Puerto Ayacucho; 112; 13 May 2004; D. García-Favreleg.; CEMT. - Aragua • 1 đo; Cuyagua; 50 m a.s.1.; 6 Jul. 2004; D. García leg.; CEMT • 1 \&; NP, Henri Pitter, Choroní; 29 Jul. 1992; Hornburg leg.; CEMT. - Barinas •

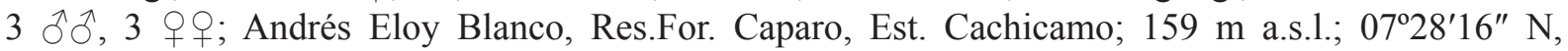

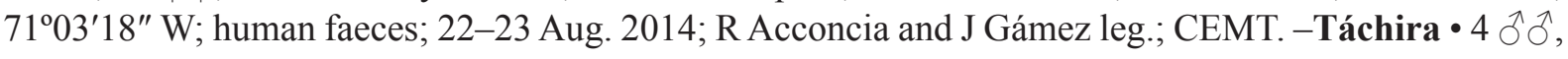


3 qक; San Cristobal, Parque Natural Paramillo; Jul. 1993; J. Blanco leg.; CEMT • 1 ô, 1 क; San Cristobal, Barrio El Lobo; Apr. 1984; B. Joffre leg.; CEMT 1 ô, 4 우; Palo Gordo, nr San Cristobal, La Alameda Farm; 1000 m a.s.1.; Apr. 1987; D. Havranek leg.; CEMT. - Vargas • 1 ○, 1 O; Vargas, La

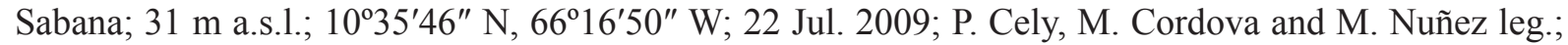
CEMT. - Yaracuy 1 ô $^{\prime}$; Bolivar Aroa; $1376 \mathrm{~m}$ a.s.l.; $10^{\circ} 0^{\prime} 0^{\prime \prime} \mathrm{N}, 68^{\circ} 0^{\prime} 0^{\prime \prime} \mathrm{W} ; 20$ Jul. 2009; M. Asmüssen,

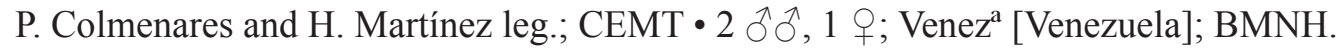

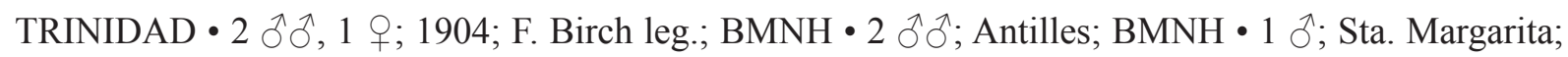

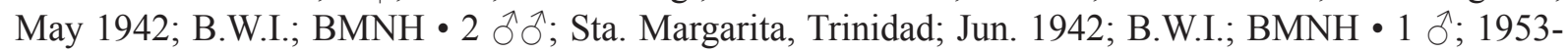

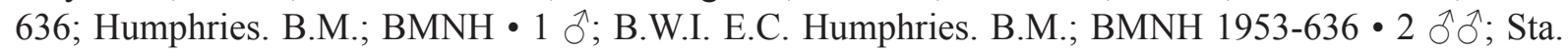
Margarita; B.W.I.; Sep. 1942; E.C. Humphries. B.M; BMNH 1953-636.

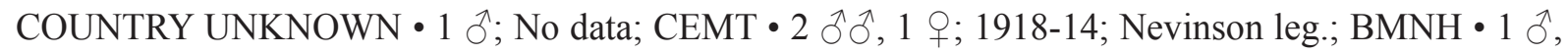
1 q; Villa Paz; BMNH • 2 ô ô; Las Adjuntas; 959 m a.s.l.; July 1926; H.E. Box leg.; BMNH.

\section{Redescription}

\section{Male}

MEASUREMENTs. Length: $19.9 \mathrm{~mm}$.

HEAD. Anterior dorsal surface rugose, extending posteriorly not reaching base of cephalic carina. Clypeus with central emargination separating two rounded clypeal teeth feebly curved dorsally. Cephalic carina higher than wide, anterior surface smooth. Median tubercle two and a half times as high as lateral tubercles, conical in shape, weakly curved posteriorly, apex rounded-truncated and never bifurcate. Apex of lateral tubercles obtuse (Fig. 17C). Ventral clypeal process truncate (see Fig. 2B).

Pronotum. Wider than long. Anterior disc of pronotum presenting truncate declivity (Fig. 17D). Row of organized ocellate punctures along anterior and posterior margins, few on lateral margins. Pronotal median disc with fine punctures. Hypomeral disc punctures separated by three times diameter of a puncture, never smooth or lacking punctation. External margin bearing single row of organized long setae, all approximately of same length (see Fig. 2F).

ABdomen. Mesosternum covered by large, ocellate setigerous punctures. Metepisternum surface shagreened microsculpture, displaying ocellate setigerous punctures. Metasternum setigerous punctures restricted mainly to lateral and anterior areas of mestasternal lobe, puncture diameter variable. Metasternal antero-median pilosity never connecting with lateral through margin of mesocoxa (see Fig. 2H). Ocellate punctures along anterior margin of each sternite. Pygidium sides of basal margin bearing row of ocellate punctures.

ELYTRA. Interstriae smooth with fine randomly distributed punctures. Striae strongly marked, with ocellate punctures separated by diameter of a puncture on elytral disc.

LEGS. Metacoxa posterior edge bearing row of organized ocellate punctures, separated by diameter of a puncture.

Parameres and lamella copulatrix. As in Fig. 17F-H.

\section{Morphological variation}

Females (Fig. 17B)

As males except for the following characters:

HEAD. Completely transversely rugose, denser on anterior portion. Cephalic carina bituberculate. 

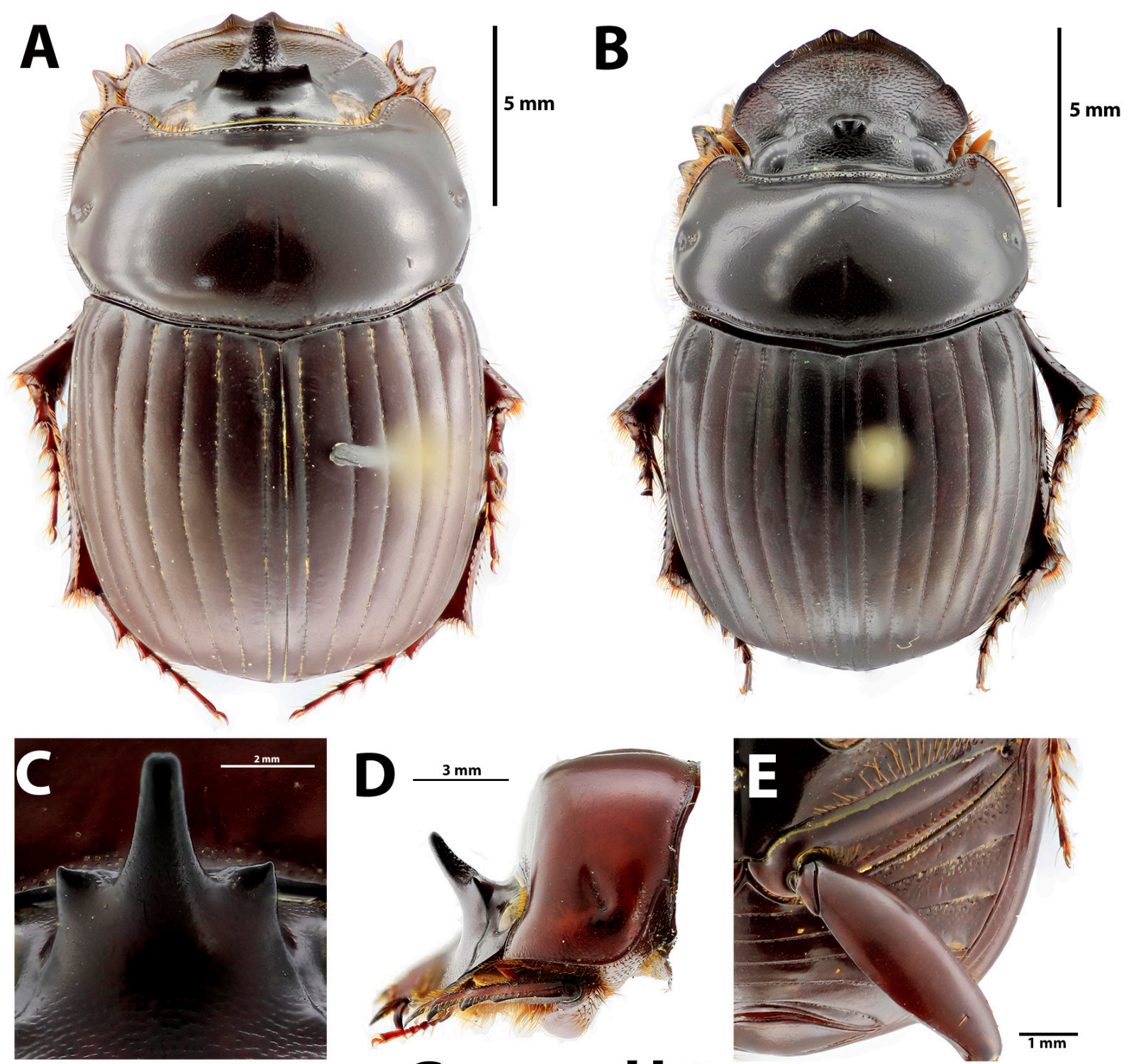

$\mathbf{F}$
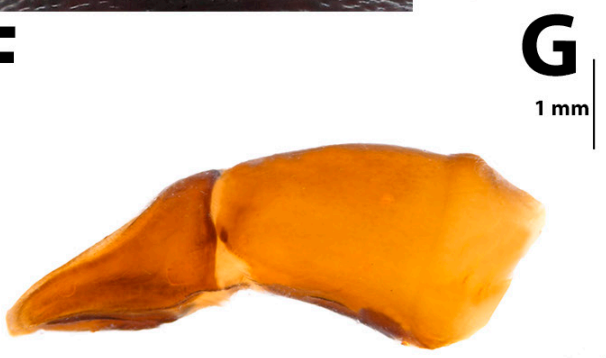

$1 \mathrm{~mm}$
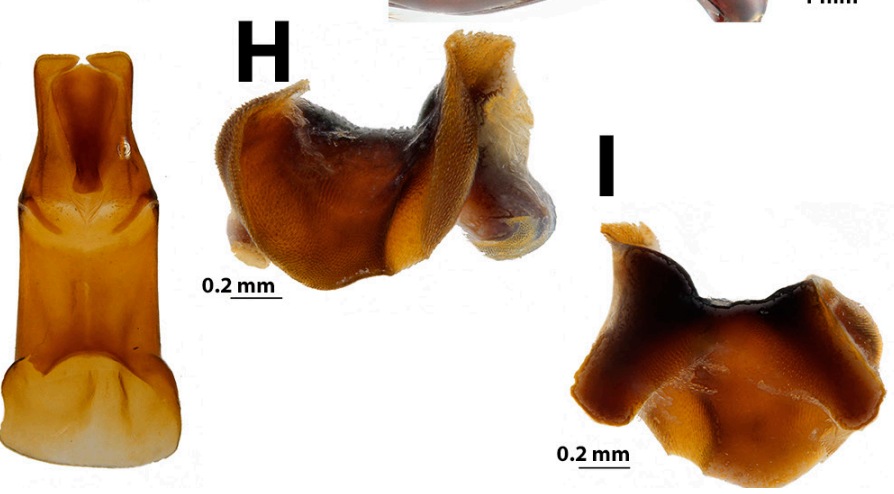

Fig. 17. Dichotomius tristis (Luederwaldt, 1923). A-B. Dorsal habitus. A. §. B. . . C. Anterior view of the cephalic carina, medial tubercle apically truncate. D. Lateral view of the pronotum, anterior declivity truncate. E. Ventral view of the metacoxa, displaying a single row of punctures on the posterior margin. F. Lateral view of the aedeagus. G. Ventral view of the aedeagus. H-I. Lamella copulatrix. 
PRonotum. Surface covered by fine punctures, denser at antero-lateral edges, ocellate punctures of margins denser, distinct on lateral sides. Hypomeron setae longer and denser than in males.

\section{Remarks}

Dichotomius tristis has historically been misidentified, as it is commonly confused with D. agenor. The holotype that Luederwaldt (1923) used to describe the species was from Venezuela, lacking information on the specific locality. This species is known to occur in Colombia, Venezuela and Brazil below 1000 metres a.s.1., in the zones of Orinocoan piedmont, dry savannas or as stated by Morrone (2001), the provinces of Los Llanos Venezolanos and Roraima.

Dichotomius (Luederwaldtinia) validipilosus (Luederwaldt, 1931)

Fig. 18, Map 15

Pinotus validipilosus Luederwaldt, 1931: 103 (original description).

Pinotus validipilosus - Blackwelder 1944: 208.

Dichotomius validipilosus - Roze 1955: 44.

\section{Diagnosis}

Dichotomius validipilosus is separated from the other species in the group by the following combination of characters: head surface subrugose. Clypeus not rounded, clypeal margin displaying projection protruding on anterior portion of clypeo-genal suture. Cephalic carina conical, median tubercle apically emarginate, lateral tubercles slightly developed. Pronotal anterior disc with declivity, median edge deeper than lateral sides resembling two underdeveloped lobes. Pronotal median disc punctation fine. Anterior and lateral edges of metasternum with long and abundant setae. Elytral interstriae microsculpture shagreened. Sixth abdominal sternite marginally lower or depressed than other sternites.

\section{Material examined}

\section{Holotype}

VENEZUELA • 1 ô; "Venézuela Caracas" [white, p]/ “Ex-Museo N. Van de Poil”" [white, p]/ "MUSÉUM PARIS 1938 COLL. A. BOUCOMONT" [green, p]/ "Typus" [red with black margins, p]/ "Pinotus validipilosus n. sp. Lueder. Det. 1931" [white, hw]; MNHN.

\section{Additional material}

COLOMBIA - La Guajira • $1 \hat{\jmath}, 1$ q; Cermanke, Rio Rancheria; 2800 m a.s.1.; Jun. 2008; Andrea Esparza leg.; CEMT. - Magdalena • 1 ; 24 km S of Sta. Marta, Campana.; $3000 \mathrm{ft}$ a.s.1.; 14 May 1973; Campbell and Howden leg.; CEMT.

VENEZUELA - Aragua • 2 $\circ$; Cuyagua; 50 m a.s.l.; 6 Jul. 2004; D. García leg.; CEMT. - Merida •

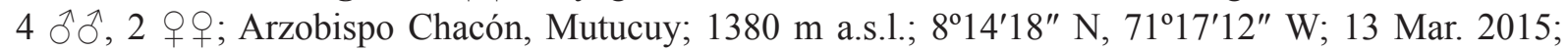
Racconcia leg.; CEMT. - Tachira • 2 $\precsim$; Palmira, La Flautera; 15 Jul. 1985; B. Joffre leg.; CEMT.

\section{Redescription}

\section{Male}

MEASUREMENTS. Length: $21.6 \mathrm{~mm}$.

HEAD. Anterior surface subrugose (Fig. 18C), extending posteriorly not reaching base of cephalic carina. Clypeus not rounded, with large central emargination separating two rounded clypeal teeth, feebly angled upwards (Fig. 18A, C). Clypeal margin distinct, projection protruding on anterior portion of 

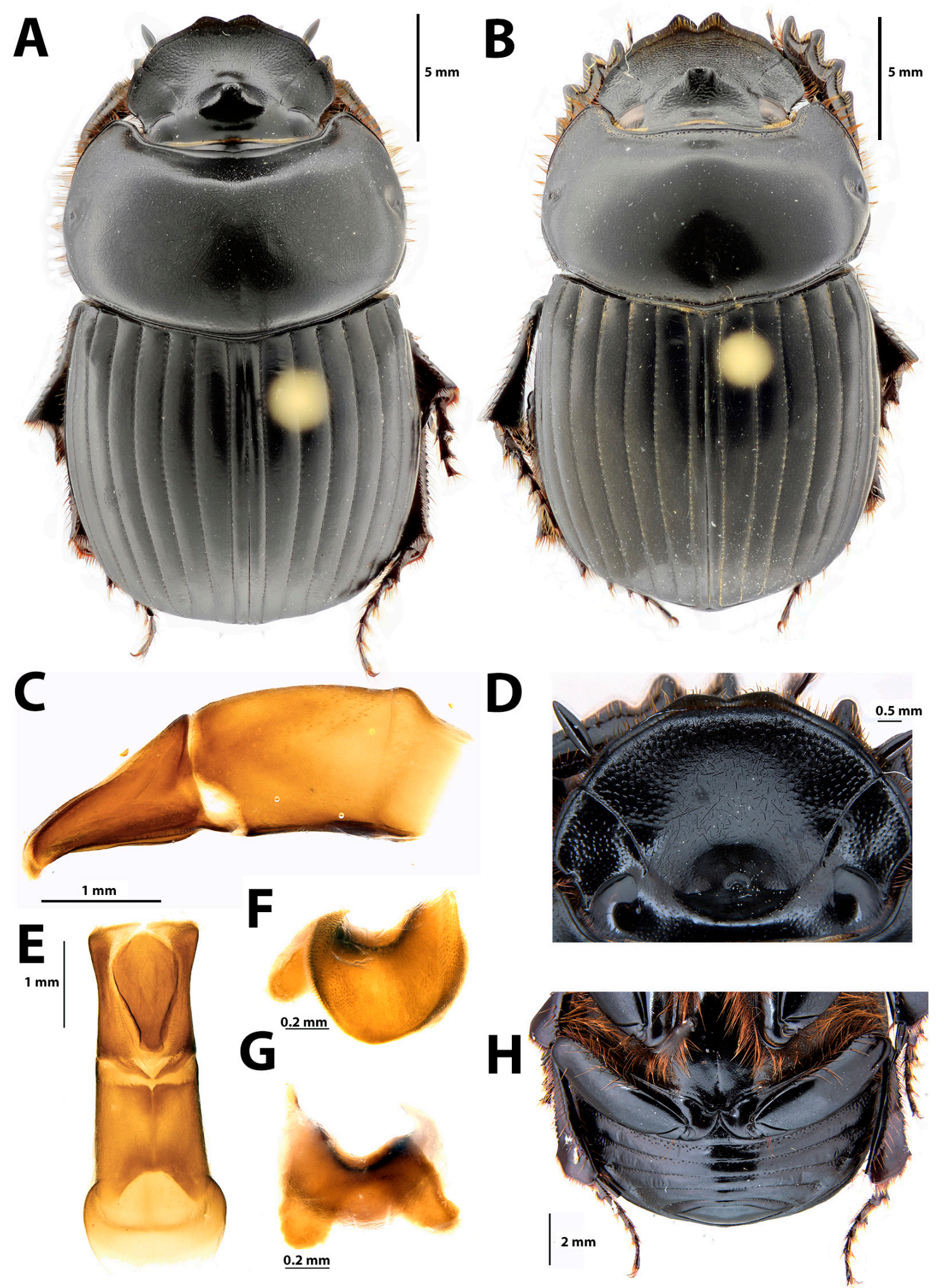

Fig. 18. Dichotomius validipilosus (Luederwaldt, 1931). A-B. Dorsal habitus. A. $\widehat{\jmath}$. B. view of the aedeagus. D. View from above of the head, basal third surface subrugose. E. Ventral view of the aedeagus. F-G. Lamella copulatrix. H. Punctures along the anterior margin of the punctuated, sixth sternite marginally lower, depressed. 
clypeo-genal suture. Cephalic carina, as wide as high, conical in shape. Median tubercle three times as high as lateral tubercles, apically emarginate. Lateral tubercles slightly developed. Ventral clypeal process truncate and broadened apically (see Fig. 2B).

Pronotum. Twice as wide as long and as wide as elytra. Pronotal median disc shiny and with fine punctures, ocellate punctures near posterior basal central margin. Anterior disc with sharp declivity, medial edge deeper than lateral sides, resembling two underdeveloped lobes (Fig. 18A). Hypomeron external margin bearing rows of disorganized setigerous punctures, median disc smooth and shiny (see Fig. 2E).

AвDOMEN. Mesosternum and metepisternum surface microsculpture shagreened, ocellate setigerous punctures separated by once diameter of a puncture. Metasternum anterior portion next to basal margin of mesosternum and margins of mesocoxa microsculpture shagreened, with dense pilosity surrounding margins of mesocoxa joining medial and lateral portions of metasternum (see Fig. 2G, Fig. 18D). Longitudinal sulcus distinctly sculpted, ending as shallow mid-fossa. Sternites ocellate punctures along anterior margins. Sixth abdominal sternite marginally lower or depressed than other sternites (Fig. 18D). Pygidium completely delimited by margin. Large punctation restricted to basal margin. Medial and apical surfaces finely punctate.

ElYTRA. Wider than long. Interstriae microsculpture shagreened (see Fig. 2J) with fine shiny punctures arranged randomly. Striae with ocellate punctures separated by once diameter of a puncture on elytral disc.

LEGS. Metacoxa surface microsculpture shagreened, posterior margin covered by row of dense setigerous punctures close together; setae dense, half the length of setae of metasternum.

Parameres and lamella Copulatrix. Fig. 18E-G.

\section{Morphological variation}

Females (Fig. 18B)

As males except for the following characters:

HEAD. Anterior surface rugose, less dense on interocular space. Cephalic carina quadrituberculate; two median tubercles higher than lateral ones.

Pronotum. Anterior disc declivity weak, not modified. Surface finely punctate, punctures firmly impressed, denser at anterolateral margins next to fossae. Medial sulcus conspicuous. Pygidium delimited by incomplete margin, faded apically.

\section{Remarks}

The distribution of $D$. validipilosus and $D$. deyrollei overlaps and, although males can easily be differentiated, the females are quite similar and can only be distinguished by the pronotal punctation, which is lacking in D. validipilosus, and the character of the sixth abdominal sternite, which is marginally lower in D. validipilosus.

\section{Discussion}

The Dichotomius agenor species group has the highest diversity of any group of Luederwaldtinia that has been revised to date (Maldaner et al. 2015; Nunes \& Vaz-de-Mello 2013; Nunes et al. 2016; Valois et al. 2017). The diversity and distribution of the species of the group were poorly known, which is not surprising given the ambiguous species boundaries, incorrect identifications and inaccurate geographic 
records of the specimens examined. Is important to emphasize that this species group shows a high degree of intraspecific variation which makes it difficult to identify specimens to the species level, leading to incorrect synonyms and descriptions of new species.

It is noteworthy that the $D$. agenor species group shares important characters with other species groups within the subgenus Luederwaldtinia. For example, D. agenor, D. assifer and D. speciosus possess an apical tooth on the meso- and metatibiae as well as the same type of pilosity and punctation pattern on the abdominal sternites (Nunes \& Vaz-de-Mello 2013; Nunes et al. 2016). However, morphological characters were found indicating closer relationships between the species contained in D. agenor species group: 1. shape of the cephalic carina, 2. pronotal shape and 3. morphology of the lamella copulatrix (e.g., imperceptible variation of the apical sclerites and slight variation in the shape of the lamella copulatrix within the internal sac of the aedeagus), highlighting some putative synapomorphies. The latter characters solidly delimit the Dichotomius agenor species group within the genus Dichotomius and, more importantly, within the subgenus Luederwaldtinia.

\section{Acknowledgements}

We would like to thank the people that in one way or another were involved in this research. Indeed, it would be difficult to thank everyone, however, we will mention institutions and people who most contributed to the success of the research. In the first instance, we thank the National Council for Scientific and Technological Development (CNPq). SMM received a scholarship from CNPq (440604/2015-0 PROTAX 2015-18); FZVM is a CNPq fellow and part of this work was funded by CNPq (Conselho Nacional de Desenvolvimento Científico e Tecnológico - CNPq 440604/2015-0, 302997/2013-0, 400681/2014-5, 440604/2015-0) and PPBio e CNPq (248299/2012-3). Also, FZV received support from ISYEB, UMR $7205 \mathrm{CNRS/MNHN.} \mathrm{We} \mathrm{would} \mathrm{like} \mathrm{to} \mathrm{extend} \mathrm{our} \mathrm{gratitude} \mathrm{to} \mathrm{the}$ curators who received us in their respective institutions and without whom completing this work would have been impossible: many thanks to Max Barclay and Michael Geiser at the BMNH; Claudia A. Medina (IAvH); Alejandro Lopera (ECC); Arturo Roig-Alsina (MACN), Nora Cabrera (MLP); Olivier Montreuil and Antoine Mantilleri (MNHN); Carlos Campaner and Sonia Casari (MZSP); Carmen Elisa Poso (MUSENUV). We would like also to thank to Dr Fernando A.B. Silva, Arturo González-Alvarado, Joana Pequito Cristóvão, Dr Marinêz Isaac Marques, Dr Felipe Franco Curcio and Dr Leonardo F. Bairos Moreira for their important and valuable considerations.

\section{References}

Arias-Buriticá J.A. \& Vaz-de-Mello F.Z. 2012. Redescripción de Dichotomius camposeabrai y D. nemericola (Coleoptera, Scarabaeidae, Scarabaeinae) com apuntes sobre su posicón sistemática. Revista Mexicana de Biodiversidad 83: 387-395. https://doi.org/10.22201/ib.20078706e.2012.2.967

Blackwelder R.E. 1944. Checklist of the coleopterous insects of Mexico, Central America, West Indies and South America. Part 2. United States National Museum Bulletin 185: 189-341.

https://doi.org/10.5479/si.03629236.185.2

Brecko J., Mathys A., De Koninck W., Leponce M., VandenSpiegel D. \& Semal P. 2014. Focus stacking: Comparing commercial top-end set-ups with a semi-automatic low budget approach. A possible solution for mass digitalization of type specimens. ZooKeys 464:1-23. https://doi.org/10.3897/zookeys.464.8615

Castelnau M. 1840. Histoire naturelle des coléoptères. In: Blanchard E. (eds) Histoire naturelle des animaux articulés. Vol. 2: 1-564. Dumenil, Paris. 
Chamorro W., Marín-Armijos D., Granda V. \& Vaz-de-Mello F.Z. 2018. Listado de especies y clave de géneros y subgéneros de escarabajos estercoleros (Coleoptera: Scarabaeidae: Scarabaeinae) presentes y presuntos para Ecuador. Revista Colombiana de Entomología 44 (1): 72-100.

https://doi.org/10.25100/socolen.v44i1.6545

Chamorro W., Marin-Armijos D., Asenjo A. \& Vaz-De-Mello F.Z. 2019. Scarabaeinae dung beetles from Ecuador: a catalog, nomenclatural acts, and distribution records. ZooKeys 826: 1-343.

https://doi.org/10.3897/zookeys.826.26488

Felsche C. 1901. Beschreibungen coprophager Scarabaeiden. Deutsche Entomologische Zeitschrift 2: $135-155$.

Halffter G. \& Matthews E.G. 1966. The natural history of dung beetles of the subfamily Scarabaeinae. Folia Entomologica Mexicana 12 (14): 1-312.

Harold E. 1869. Révision des espèces qui rentrent dans le genre Pinotus Erichs. L'Abeille 6: 124-144.

Harold E. 1880. Verzeichniss der von Dr. Steinheil in Neu-Granada gesammelten Coprophagen Lamellicornien. Stettiner entomologische Zeitung 41: 13-46.

Howden H.F. \& Young O.P. 1981. Panamanian Scarabaeinae taxonomy, distribution and habits (Coleoptera: Scarabaeidae). Contributions of the American Entomological Institute 18: 1-204.

ICZN [International Commission on Zoological Nomenclature]. 1999. International Commission on Zoological Nomenclature. Fourth Edition. The International Trust for Zoological Nomenclature, London.

Kohlmann B. \& Solís A. 1997. El género Dichotomius (Coleoptera: Scarabaeidae) en Costa Rica. Giornale Italiano di Entomologia 8: 343-382.

Larsen T.H. 2011. Dung beetles of the Kwamalasamutu region, Suriname (Coleoptera: Scarabaeidae: Scarabaeinae) In: O'Shea B.J., Alonso L.E. \& Larsen T.H. (eds) A Rapid biological Assessment of the Kwamalasamutu Region, Southwestern Suriname. RAP Bulletin of Biological Assessment 63. Conservation International, Arlington, VA.

López-Guerrero I. 2005. Los Dichotomius (Coleoptera: Scarabaeidae, Dichotomiini) de la fauna de México. Boletín de la Sociedad Entomológica Aragonesa 36: 195-209.

Luederwaldt H. 1923. Neue Pinotus-Arten. Revista do Museu Paulista 14: 1-13.

Luederwaldt H. 1929. As espécies Brasileiras do gênero Pinotus. Revista do Museu Paulista 16: 1-173.

Luederwaldt H. 1931. Tres especies novas de Pinotus, supplementos a Memoria "As espécies Brasileiras do gênero Pinotus". na "Revista do Museu Paulista" Tomo XVI, 1929, P603SS. Revista do Museu Paulista 17: 353-361.

Luederwaldt H. 1935. Zur Kenntnis der Gattung Pinotus (Coleoptera: Scarabaeidae). Revista Entomológica 5: 334-342.

Luederwaldt H. 1936. Notas complementares "As espécies Brasileiras do gênero Pinotus". Revista do Museu Paulista 20: 207-216.

Maldaner M.E., Nunes R.V. \& Vaz-de-Mello F.Z. 2015. Taxonomic revision of the Dichotomius speciosus (Waterhouse, 1891) species group (Coleoptera: Scarabaeidae: Scarabaeinae). Zootaxa 3986 (5): 549560. https://doi.org/10.11646/zootaxa.3986.5.2

Martínez A. 1951. La invalidez del nombre genérico Pinotus Erichson y dos nuevas sinonímias (Col. Scarab.). Anales de La Sociedad Cientifica Argentina 5: 138-142. 
Martínez A. 1959. Catalogo de los Scarabaeidae Argentinos. Revista del Museo Argentino de Ciencias Naturales "Bernardino Rivadavia" 5 (1): 1-126.

Medina C.A., Lopera-Toro A., Vitolo A. \& Gill B. 2001. Escarabajos coprófagos (Coleoptera: Scarabaeinae) de Colombia. Biota Colombiana 2: 131-144.

Medina C.A., Molano F. \& Scholtz C.H. 2013. Morphology and terminology of dung beetles (Coleoptera: Scarabaeidae: Scarabaeinae) male genitalia. Zootaxa 3626 (4): 455-676.

https://doi.org/10.11646/zootaxa.3626.4.3

Morrone J.J. 2001. Toward a cladistic model for the Caribbean subregion: Delimitation of areas of endemism. Caldasia 23 (1): 43-76.

Nunes R.V., Carvalho M.S.G. \& Vaz-de-Mello F.Z. 2016. Taxonomic review of the Dichotomius (Luederwaldtinia) assifer (Eschscholtz) species group (Coleoptera: Scarabaeidae). Zootaxa 4078 (1): 230-244. https://doi.org/10.11646/zootaxa.4078.1.21

Nunes R.V. \& Vaz-de-Mello F.Z. 2013. New brachypterous species of Dichotomius Hope, with taxonomic notes in the subgenus Luederwaldtinia Martínez (Coleoptera: Scarabaeidae: Scarabaeinae). Zootaxa 3609 (4): 411-420. https://doi.org/10.11646/zootaxa.3609.4.3

Pereira F. 1941. Pinotus de la república de Argentina (Col. Lam. Copridae). Anales de la Sociedad Cientifica Argentina 1941: 262-267.

Pereira F.S. 1954. O genero Scatonomus Er. (Coleoptera, Scarabaeidae). Revista Brasileira de Entomologia Sao Paulo 1: 53-172.

Ratcliffe B.C. 2002. A checklist of the Scarabaeoidea of Panama. Zootaxa 32: 1-48. https://doi.org/10.11646/zootaxa.32.1.1

Ratcliffe B.C., Jameson M.L., Figueroa L., Cave R.V. \& Paulsen M.L. 2015. Beetles (Coleoptera) of Peru: a survey of the families. Scarabaeoidea. Journal of the Kansas Entomological Society 88 (2): 186-207. https://doi.org/10.2317/kent-88-02-186-207.1

Roze J.A. 1955. Lista preliminar de la familia Scarabaeidae sensu lato de Venezuela. Boletin del Museo de Ciencias Naturales 1 (1): 39-63.

Sarmiento-Garcés R. \& Amat-García G. 2014. Escarabajos del género Dichotomius Hope 1838 (Scarabaeidae: Scarabaeinae) en Colombia. Fauna de Colombia, Monografía 4. Universidad Nacional de Colombia, Bogotá, Colombia.

Schoolmeesters P. 2018. Scarabs: World Scarabaeidae Database. In: Roskov Y., Abucay L., Orrell T., Nicolson D., Flann C., Bailly N., Kirk P., Bourgoin T., DeWalt R.E., Decock W. \& De Wever A. (eds) Species 2000 \& ITIS Catalogue of Life, 2016 Annual Checklist. Available from www.catalogueoflife. org/annual-checklist/2016 [accessed 29 Jan. 2021].

Shorthouse D.P. 2010. SimpleMappr, an online tool to produce publication-quality point maps. Available from http://www.simplemappr.net [accessed 21 Jan. 2018].

Tarasov S. \& Génier F. 2015. Innovative Bayesian and parsimony phylogeny of dung beetles (Coleoptera, Scarabaeidae, Scarabaeinae) enhanced by ontology-based partitioning of morphological characters. PLoS ONE 10: e0116671. https://doi.org/10.1371/journal.pone.0116671

Tarasov S. \& Solodovnikov A.Y. 2011. Phylogenetic analyses reveal reliable morphological markers to classify mega-diversity in Onthophagini dung beetles (Coleoptera: Scarabaeidae: Scarabaeinae). Cladistics 27: 490-528. https://doi.org/10.1111/j.1096-0031.2011.00351.x 
Valois M.C., Vaz-de-Mello F.Z. \& Silva F.A.B. 2017. Taxonomic revision of the Dichotomius sericeus (Harold, 1867) species group (Coleoptera: Scarabaeidae: Scarabaeinae). Zootaxa 4277 (4): 503-530. https://doi.org/10.11646/zootaxa.4277.4.3

Vaz-de-Mello F.Z., Edmonds W.D., Ocampo F.C. \& Schoolmeesters P. 2011. A multilingual key to the genera and subgenera of the subfamily Scarabaeinae of the New World (Coleoptera: Scarabaeidae). Zootaxa 2854: 1-73. https://doi.org/10.11646/zootaxa.2854.1

Vaz-de-Mello F.Z. \& Nunes R.V. 2016. New species, redescription and taxonomic notes in the Dichotomius (Luederwaldtinia) batesi (Harold) species group (Coleoptera: Scarabaeidae: Scarabaeinae). Zootaxa 4139 (2): 294-300. https://doi.org/10.11646/zootaxa.4139.2.12

Zunino M. 1983. Essai préliminaire sur l'évolution des armures génitales des Scarabaeinae, par rapport à la taxonomie du groupe et à l'évolution du comportement de nidification (Coleoptera, Scarabaeidae). Bulletin de la Societé entomologique de France 88: 531-542.

Manuscript received: 6 May 2019

Manuscript accepted: 17 November 2020

Published on: 11 February 2021

Topic editor: Gavin Broad

Section editor: Max Barclay

Desk editor: Kristiaan Hoedemakers

Printed versions of all papers are also deposited in the libraries of the institutes that are members of the EJT consortium: Muséum national d'histoire naturelle, Paris, France; Meise Botanic Garden, Belgium; Royal Museum for Central Africa, Tervuren, Belgium; Royal Belgian Institute of Natural Sciences, Brussels, Belgium; Natural History Museum of Denmark, Copenhagen, Denmark; Naturalis Biodiversity Center, Leiden, the Netherlands; Museo Nacional de Ciencias Naturales-CSIC, Madrid, Spain; Real Jardín Botánico de Madrid CSIC, Spain; Zoological Research Museum Alexander Koenig, Bonn, Germany; National Museum, Prague, Czech Republic.Appendix 


\section{Appendix}

Distribution maps.
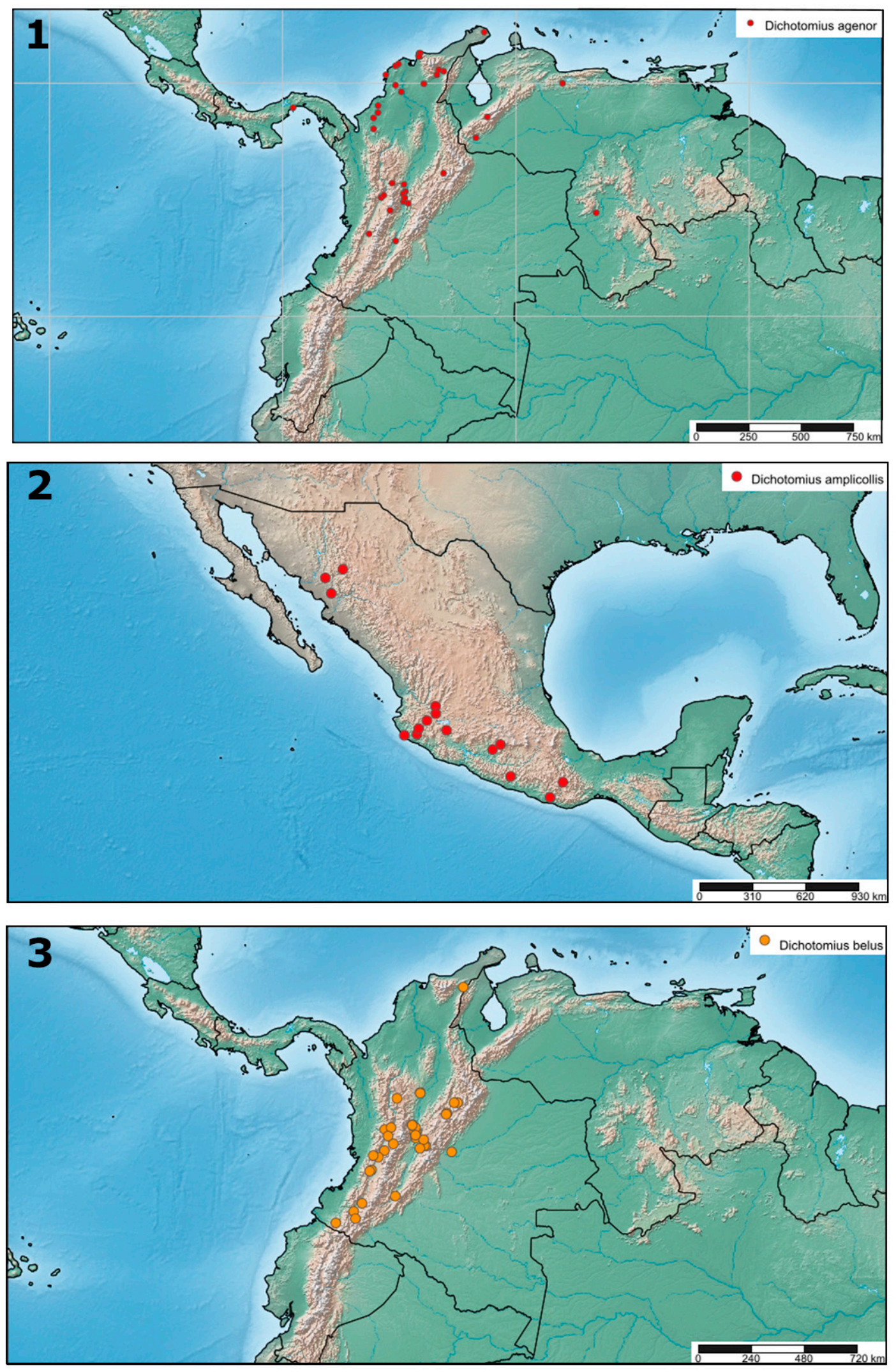
MONTOYA-MOLINA S. \& VAZ-DE-MELLO F.Z., Dichotomius agenor species group review
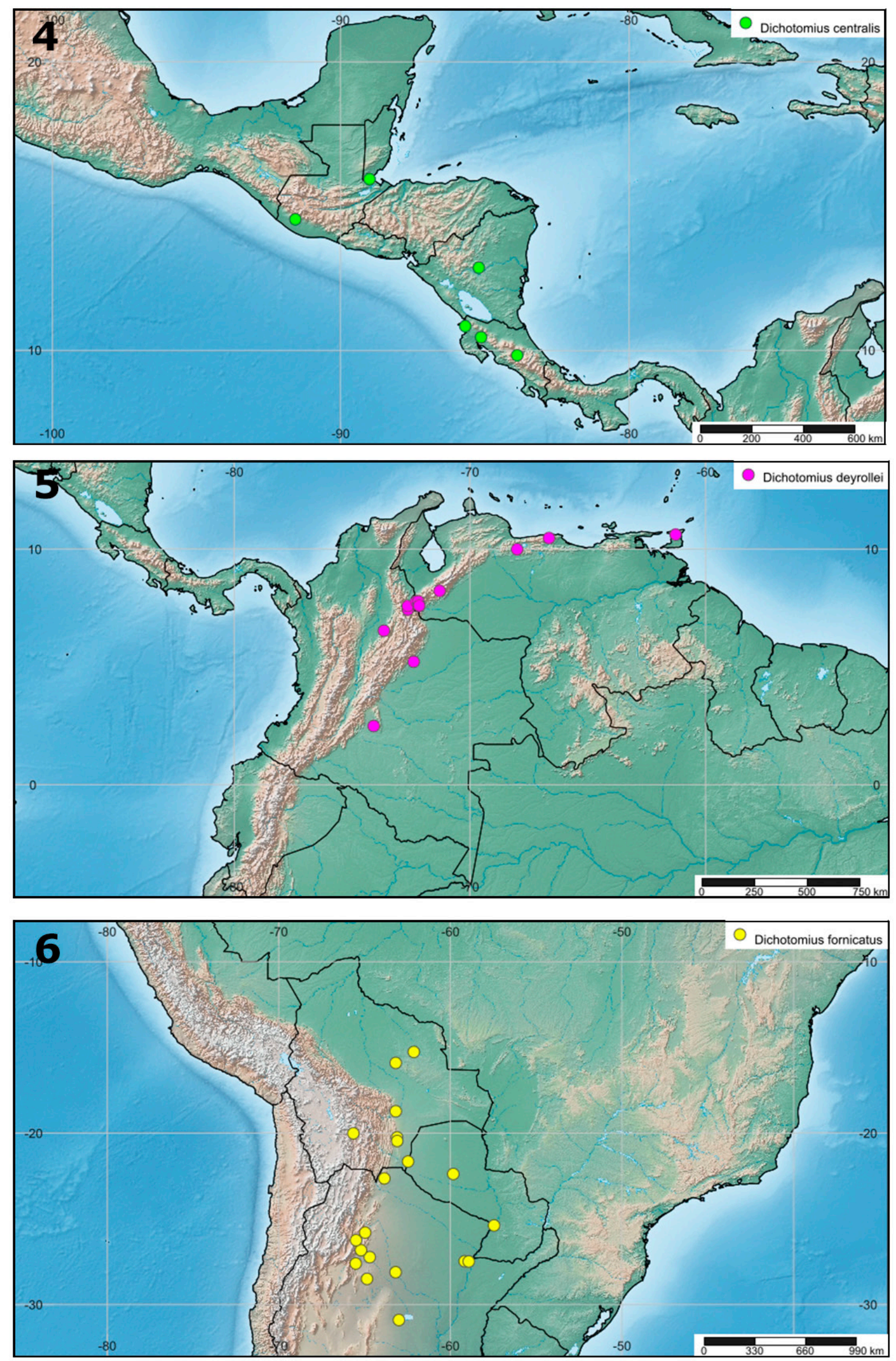

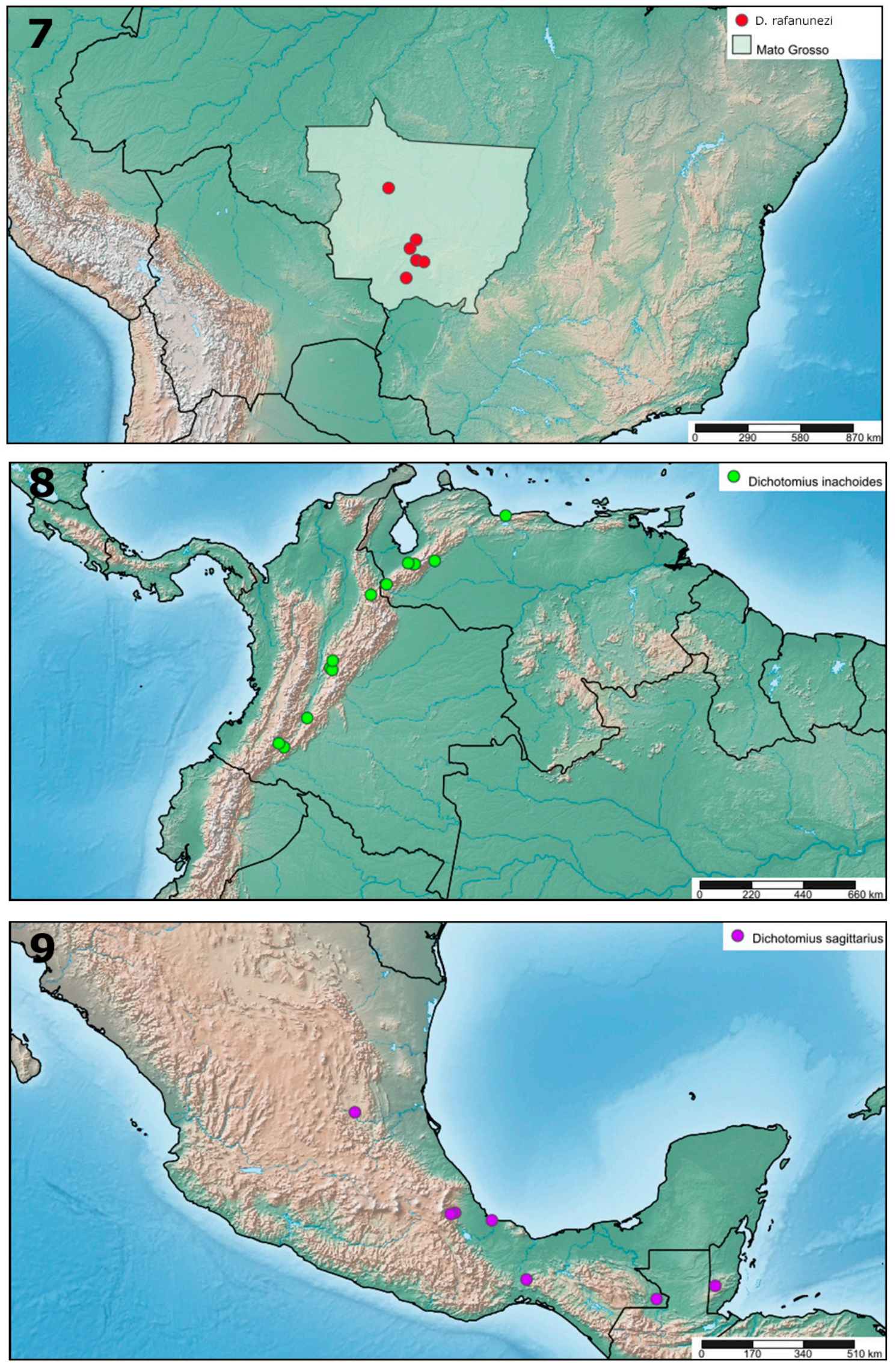

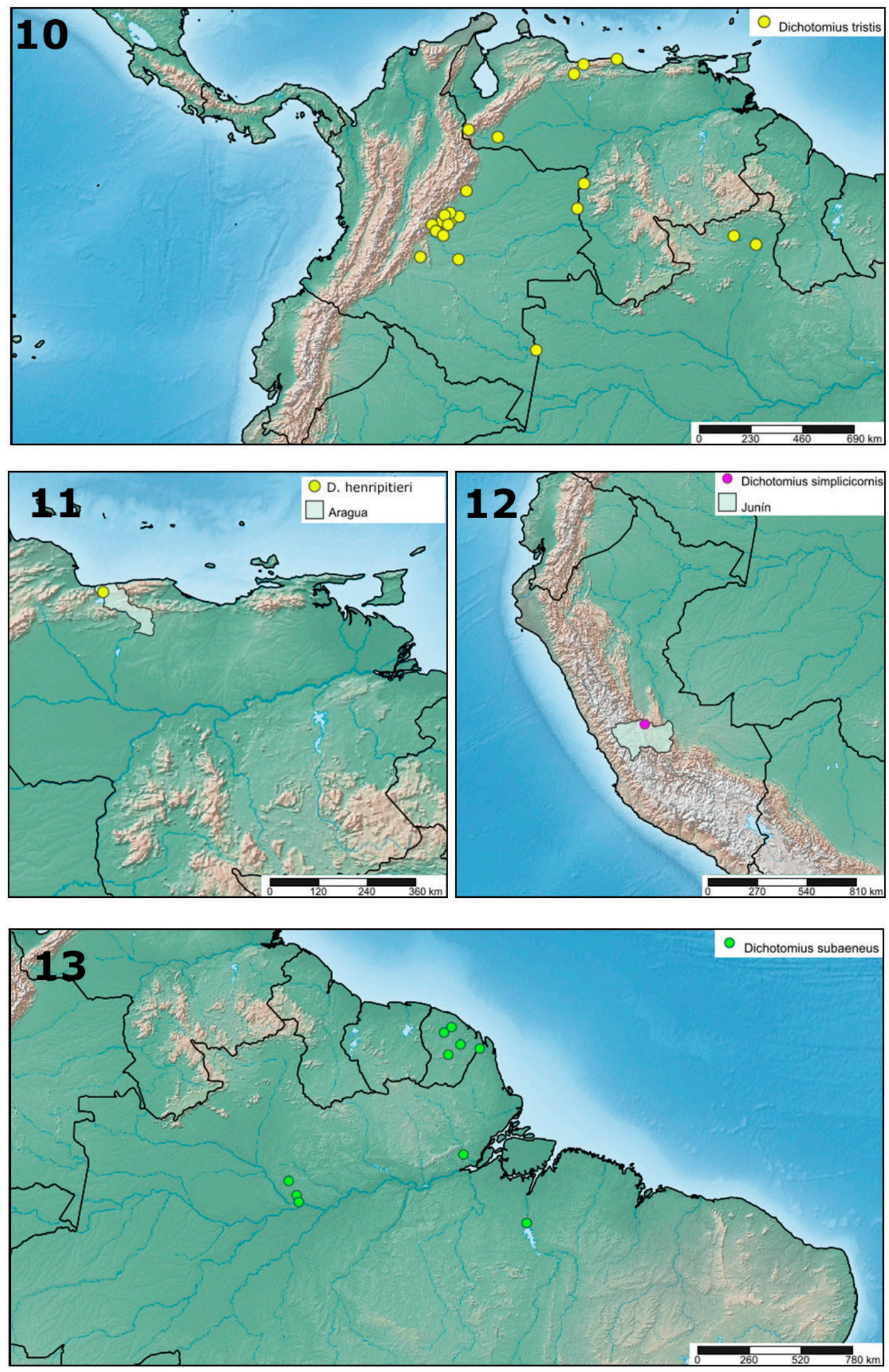

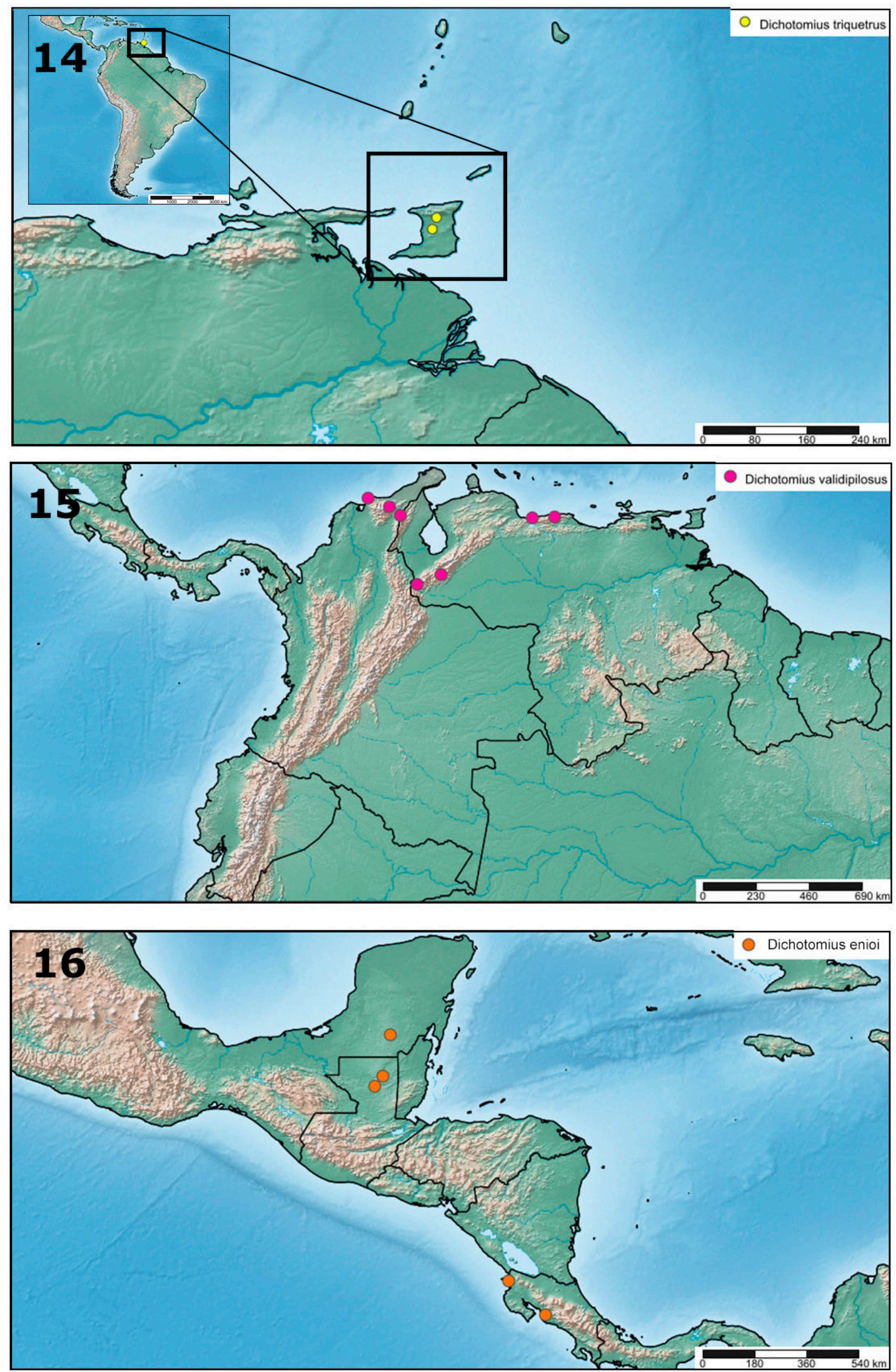